\title{
HEINONLINE
}

Citation: 97 Marq. L. Rev. 523 2013-2014

Content downloaded/printed from

HeinOnline (http://heinonline.org)

Fri Nov 7 16:22:04 2014

-- Your use of this HeinOnline PDF indicates your acceptance of HeinOnline's Terms and Conditions of the license agreement available at http://heinonline.org/HOL/License

-- The search text of this PDF is generated from uncorrected OCR text.

-- To obtain permission to use this article beyond the scope of your HeinOnline license, please use:

https://www.copyright.com/ccc/basicSearch.do?

\&operation $=$ go\&search Type $=0$

\&lastSearch $=$ simple\&all $=$ on\&titleOrStd No $=0025-3987$

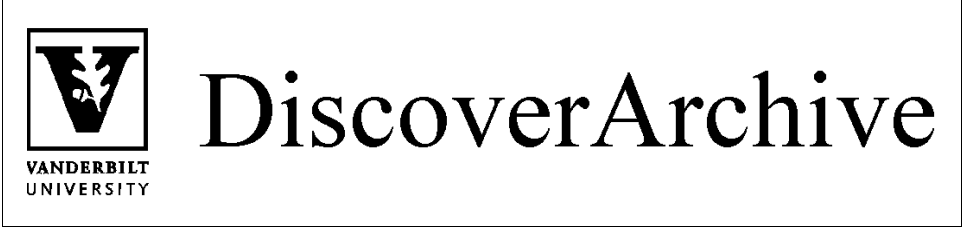

Retrieved from DiscoverArchive,

Vanderbilt University's Institutional Repository

This work was originally published as Nancy J. King, Sentencing and Prior

Convictions: The Past, the Future, and the End of the Prior-conviction

Exception to Apprendi in 97 Marq. L. Rev. 523 2013-2014. 
MARQUETTE LAW REVIEW

\begin{tabular}{lll}
\hline Volume 97 & Spring 2014 & Number 3 \\
\hline
\end{tabular}

\title{
BARROCK LECTURE
}

MARQUETTE UNIVERSITY LAW SCHOOL

NOVEMBER 18, 2013

\section{SENTENCING AND PRIOR CONVICTIONS: THE PAST, THE FUTURE, AND THE END OF THE PRIOR-CONVICTION EXCEPTION TO APPRENDI}

\author{
NANCY J. KING*
}

I. INTRODUCTION

II. REPEAT-OFFENDER PUNISHMENT: A HISTORICAL OVERVIEW .....526

A. Punishing the Marked Offender: Colonial Times Through the 1830 s

B. Discovering the Recidivist-Penitentiaries and the

Deviant Type-1820-1880

C. Technology to the Rescue-Photos, Bertillonage, and

Fingerprints-1880-1930

D. Parole and Probation for Some, Incapacitation for the

Dangerous-1890-1970

E. A Punitive Turn-Three Strikes and Other Mandatory

Sentencing Laws-1970 on.

III. JUSTIFYING AND CALIBRATING PENALTIES FOR REPEAT

OFFENDERS: THE MISMATCH BETWEEN THEORY,

RESEARCH, AND PRACTICE.

A. Deterrence: Weak Effects

* Speir Professor of Law, Vanderbilt University Law School. The author delivered a version of this Essay at Marquette University Law School as the George and Margaret Barrock Lecture on Criminal Law, on November 18, 2013. Sean Mahard provided outstanding research assistance. 
B. Incapacitating the Dangerous: Predicting Risk from

Criminal History. 539

1. Concerns About the Reliability of Risk Predictions Based upon Criminal History. .542

2. Costs of Increasing Sentences Based on Predictions from Criminal History: Exacerbating Racial Bias

C. Just Deserts in Proportion to Blame: A Mismatch with

Repeat-Offender Penalties.

IV. THE PROCESS FOR CHARGING AND PROVING PRIOR

CONVICTIONS THAT RAISE SENTENCE RANGES: A

CHANGING CONSTITUTIONAL LANDSCAPE. 550

A. Apprendi v. New Jersey, Alleyne v. United States, and the

Exception for Prior Convictions

B. No Clear Historical Basis for the Exception .552

C. Precedent: Why Almendarez-Torres and Other Cases Do

Not Support the Exception .555

D. Policy: Managing Jury Prejudice .558

E. Stare Decisis: Eroded Doctrine, Shifting Votes 562

V. CONCLUSION. .564

VI. APPENDIX: LAW ON CHARGING PRIOR CONVICTIONS, BY STATE (YEAR STATEHOOD) 


\section{INTRODUCTION}

Punishing prior offenders more severely than first offenders is a principle that legislatures in this country have endorsed with unique enthusiasm. ${ }^{1}$ Statutes instruct judges to use criminal history when selecting an appropriate sentence from within the range designated for an offense $e^{2}$ and regularly increase the range of punishment ${ }^{3}$ for prior offenders beyond what would be permissible for defendants with clean records. ${ }^{4}$ This Essay argues that statutes that increase penalties for repeat offenders too often fail to accomplish their intended purposes and that the procedures used to impose such sentences are constitutionally suspect. ${ }^{s}$

1. JULIAN V. ROBERTS, PUNISHING PERSISTENT OFFENDERS: EXPLORING COMMUNITY AND OFFENDER PERSPECTIVES 2-3 (2008) ("[C]riminal record is more important than any other aggravating or mitigating factor."); id. at 12, 116 (comparing sentencing law in several other countries where prior offenses lead to much smaller increases in punishment); Michael Tonry, Race, Ethnicity, and Punishment, in THE OXFORD HANDBOOK OF SENTENCING AND CORRECTIONS 53, 77 (Joan Petersilia \& Kevin R. Reitz eds., 2012) (noting that unlike most countries that increase sentences for new crimes by a few months for prior convictions, in the United States 'the 'recidivist premium' often doubles or triples the sentence"). For additional comparative treatment, see generally volume 76, issue 1 of Law and Contemporary Problems (2013).

2. E.g., Kevin R. Reitz, The Illusion of Proportionality: Desert and Repeat Offenders, in Previous CONVICTIONS AT SENTENCING: THEORETICAL AND APPLIED PERSPECTIVES 137, 138-43 (Julian V. Roberts \& Andrew von Hirsch eds., 2010) [hereinafter Roberts \& von Hirsch] (noting statutes may designate the weight criminal history should carry); Michael Tonry, Legal and Ethical Issues in the Prediction of Recidivism 11 (Univ. of Minn. Law Sch. Legal Studies Research Paper Series, Working Paper No. 13-51, 2013) ("Under most sentencing guidelines systems, third or fourth convictions can result in sentences two-to-four times longer than are received by first offenders.").

3. See Nancy J. King \& Brynn E. Applebaum, Alleyne on the Ground, Facts Affecting Eligibility for Probation and Parole (work in progress) (on file with authors) (collecting state statutes increasing minimum terms of incarceration).

4. The most well-known examples are three strikes laws and dangerous, persistent, multiple, habitual, or career offender laws. See, e.g., D.C. CODE § 22-1804 (Supp. 2012) (providing that a repeat offender can receive three times the statutory maximum if the offender has been convicted of the same or a similar crime twice before); Beth Caldwell, Twenty-Five to Life for Adolescent Mistakes: Juvenile Strikes as Cruel and Unusual Punishment, 46 U.S.F. L. REV. 581, 645-53 (2012) (collecting two and three strikes laws in appendix). A prior conviction may aggravate murder to a capital offense, e.g., FLA. STAT. $\S 921.141(5)(\mathrm{b})$ (Supp. 2013), or a misdemeanor to a felony, e.g., People v. Barclay, $159 \mathrm{Cal}$. Rptr. 3d 277, 280-81 (Cal. Ct. App. 2013); People v. Schreiber, 226 P.3d 1221, 1223 (Colo. App. 2009) (collecting authority from other states). In Wisconsin, a prior conviction can transform a civil infraction into a criminal offense. State v. Verhagen, 827 N.W.2d 891, 896 (Wis. Ct. App. 2013).

5. This Essay does not address Eighth Amendment concerns about repeat-offender punishment or the use of criminal history in investigation, pretrial release, corrections administration, or parole. 
Part I traces the history of efforts to identify which defendants have criminal records, a story important to both claims. Part II explains why repeat-offender penalties fall short of goals for deterrence, incapacitation, and retribution, and how relying heavily on criminal history in setting sentences contributes to the racially lopsided profile of punishment in America today. Turning to the constitutional regulation of the sentencing process, Part III critiques the potential justifications for the prior-conviction exception to the rule in Apprendi v. New Jersey ${ }^{6}$ and argues that the exception should be abandoned.

\section{REPEAT-OFFENDER PUNISHMENT: A HISTORICAL OVERVIEW}

\section{A. Punishing the Marked Offender: Colonial Times Through the 1830s}

In early America, various statutes mandated stiffer sentences for repeat offenders.' But without photography or fingerprints, courts had no reliable way of determining if a defendant was lying about his past. Court records included the name and age of each convicted person, information easily fabricated by those accused of a subsequent charge. To cope, early American courts often used the same cheap identification method used in Europe for centuries-marking or branding the body of the person convicted. ${ }^{8}$

Branding first offenders was a common practice after the Founding that lasted into the early nineteenth century. Many felonies were punishable by execution, but a defendant convicted for the first time could seek "benefit of clergy," essentially a reprieve from execution granted at the discretion of the judge. If granted, the defendant would be branded instead of put to death. ${ }^{9} \quad$ For example, in 1801, future

6. 530 U.S. 466 (2000) (holding that the right to a jury finding of every element of a criminal offense is violated when facts that increase the sentencing range beyond that permitted for the offense of conviction are found at sentencing by a judge).

7. SIMON A. COLE, SUSPECT IDENTITIES: A History OF FINGERPRINTING AND CRIMINAL IDENTIFICATION 13-14 (2d prtg. 2002); JOHN PRATT, GOVERNING THE DANGEROUS: DANGEROUSNESS, LAW AND SOCIAL CHANGE 9 (1997). For example, in East Jersey, a third-offense drunkard could be whipped. A first- and second-offense thief had to make full restitution. SAMUEL WALKER, POPULAR JUSTICE: A HISTORY OF AMERICAN CRIMINAL JUSTICE 32-33 (2d ed. 1998). A 1779 Virginia law provided escalating penalties for sellers of diseased or unwholesome meat, bread, or drink, including pillory for a second offense, imprisonment and fine for a third offense, and six months hard labor "every time after." An Act Prescribing the Punishment of Those Who Sell Unwholesome Meat or Drink, ch. 53 (1779), 12 Laws Va. 336 (William Waller Hening ed., 1823); see also infra note 12.

8. COLE, supra note 7, at 7; ROBERTS, supra note 1, at 4-6 (discussing the benefit of clergy and branding in England).

9. Marci A. Hamilton, Religious Institutions, the No-Harm Doctrine, and the Public 
president Andrew Jackson, sitting as a judge in Tennessee, granted benefit of clergy to a fellow convicted of delivering a "mortal bruise" to a man's head with an oak plank. According to the court records, the defendant was immediately "burned in the left hand with the letter M." 10 The brand identified him as a convicted felon and prevented him from claiming the privilege a second time, guaranteeing that any additional felony would be his last." Marking bodies was also used for non-capital crimes in the eighteenth century. The punishment for some first offenders was to lose one ear; second offenders lost the other. ${ }^{12}$

Good, BYU L. REV. 1099, 1132 (2004) (noting that the "benefit of clergy never functioned as a special privilege for clergy" in the colonies and was instead "merely a tool" to avoid applying the death penalty to first-time felonies); e.g., Act of Nov. 27, 1789, ch. 22, § 5, 1789 Va. Acts 14, 15 (providing that for crimes "allowed benefit of clergy the person shall be burned in the hand for every such offence"); A. Leon Higginbotham, Jr. \& Anne F. Jacobs, The "Law Only As an Enemy": The Legitimization of Racial Powerlessness Through the Colonial and Antebellum Criminal Laws of Virginia, 70 N.C. L. REV. 969, 1009-10 (1992) (discussing the use of clergy and branding); Nancy J. King, The Origins of Felony Jury Sentencing in the United States, 78 CHI.-KENT L. REV. 937, 948 (2003); John H. Langbein, Shaping the Eighteenth-Century Criminal Trial: $A$ View From the Ryder Sources, 50 U. CHI. L. REV. 1, 37-41, 37 n.145 (1983); see also Jack Kenny Williams, Crime and Punishment in South Carolina, 1790-1860, 233, 246-49, 298 (1953) (unpublished Ph.D. dissertation, Emory University) (on file with Emory University Library and author) (reporting that, in South Carolina, twenty-two crimes carried the death penalty as late as 1850 and branding "ceremonies," used until 1833 for those "clergied," were well attended, and courts would burn the letter $\mathrm{T}$, for thief, and $\mathrm{M}$, for manslaughter, into thumb, cheek, or, in rare cases, forehead).

10. State v. Childress (Mero Dist. Super. Ct. Nov. 19, 1801) (order allowing benefit of clergy), as reprinted in ANDREW JACKSON, LEGAL PAPERS OF ANDREW JACKSON 213-15 (James W. Ely, Jr. \& Theodore Brown, Jr. eds., 1988); see also State v. Humphreys, 1 Tenn. 306, 307 (Tenn. Super. L. \& Eq. 1808) (noting the court's pronounced sentence for a horse thief convicted in 1808: "That he be branded in the presence of the Court, on the inside of the left hand with the letter $\mathrm{H}$, and on the inside of the right hand with the letter $\mathrm{T}$, between the hours of twelve and four o'clock this day, and immediately taken to the common whipping. post, and there receive thirty-nine lashes on his bare back").

11. Some evidence suggests that the marking of offenders was not consistently employed. By 1774, branding with a cold iron was habitual practice in Virginia, prompting the author of a leading treatise on the justices of the peace in Virginia to remark that branding "can scarcely be called even so much as a slight Punishment, but rather a piece of absurd Pageantry" as the "Iron" is "scarcely heated." King, supra note 9, at 948 (citing Hugh F. Rankin, Criminal Trial Proceedings in the General Court of Colonial Virginia, 72 VA. MAG. HIST. \& BIOGRAPHY 50, 67 (1964) (quoting RICHARD STARKE, THE OFFICE AND AUTHORITY OF A JUSTICE OF PEACE EXPLAINED AND DIGESTED, UNDER PROPER TITLES $87-88(1774)))$.

12. A 1705 Virginia statute commanded that those sentenced for stealing a pig for the second time should also be rendered earless. L. L. C., Jr. \& T. G. L., Recidivism and Virginia's "Come-Back" Law, 48 VA. L. REV. 597, 598 (1962) (citing An Act Against Stealing Hogs, ch. 14 (1705), 3 Laws of Va. 276-77 (William Waller Hening ed., 1823)); see also

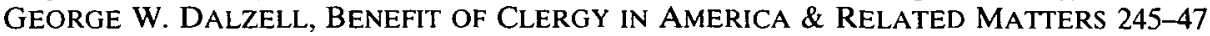
(1955) (discussing branding and ear cropping provisions in Vermont, not abolished until 1797, 
Although branding was abolished in federal courts in 1790 , it persisted in the states. ${ }^{13}$ In state courts, branding was replaced by terms of incarceration only gradually over several decades, as states built their first prisons and enacted new criminal codes. ${ }^{14}$ Branding was part of sentencing in Tennessee through the $1820 \mathrm{~s},{ }^{15}$ persisted in South Carolina until $1833,{ }^{16}$ and did not end in North Carolina until $1854 .^{17}$

\section{B. Discovering the Recidivist-Penitentiaries and the Deviant Type- $1820-1880$}

The construction of the first penitentiaries ushered in a new form of punishment: lengthy terms of incarceration. Prisons were, in theory, places of "penitence and reformation," where criminals could be removed from corrupting influences though discipline and be "cured" of their criminality. ${ }^{18}$ In practice, prisons in many states were "extraordinarily brutal" places where more than one in six prisoners died in custody. ${ }^{19}$ If a released offender was convicted of another crime, the spurned opportunity for penitence provided a justification for more

and branding as punishment for manslaughter and larceny in Texas, not ended until 1848). "Ear cropping" was also an authorized punishment in North Carolina. Id. at 258, 260.

13. DALZELL, supra note 12, at 233-35 (noting that in 1778 "benefit of clergy was an incident of the criminal law in twelve of the signatory states" where it persisted for more than ninety years, although eliminated in federal courts in 1790).

14. Jeffrey K. Sawyer, "Benefit of Clergy" in Maryland and Virginia, 34 AM. J. LEGAL HIST. 49, 66-67 (1990) (noting that the benefit of clergy was abolished in Virginia in 1796 and Maryland in 1807 by laws providing that every person convicted of felonies before deemed clergyable shall undergo imprisonment, and noting that Virginia's new law coincided with construction of a new prison in Richmond). For a listing of the dates that each state built its first penitentiary and enacted a new criminal code, see King, supra note 9, at 990-93.

15. E.g., Crenshaw v. State, 8 Tenn. (Mart. \& Yer.) 122, 123 (1827) (noting that sentence for horse thief included being "branded in the brawn of the left thumb H. T.").

16. Williams, supra note 9, at 233; see also JACKSON, supra note 10, at 213 (branding ended in Tennessee in 1829). For slaves, however, the practice continued. In Virginia, for example, convicted slaves who escaped hanging or being sold to slave traders as punishment, see generally Philip J. Schwarz, The Transportation of Slaves from Virginia, 1801-1865, 7 SLAVERY \& ABOLITION 215 (1986), were considered too valuable to incarcerate in Virginia's new penitentiary. Instead, they were "burned in the palm of the left hand with a hot poker" in court, then "taken immediately to the whipping post" and lashed. Robert M. Saunders, Crime and Punishment in Early National America: Richmond, Virginia, 1784-1820, 86 VA. MAG. OF HIST. \& BIOGRAPHY, Jan. 1978, at 33, 42.

17. DALZELL, supra note 12 , at $259-60$.

18. LAWRENCE M. Friedman, CRIME AND PUNISHMENT IN AMERICAN HISTORY 7782 (1993).

19. Id. at 90 (noting that, in $1870,41 \%$ of Alabama prisoners died and that, during the two prior years, the figure had been $17 \%$ and $18 \%$, respectively). The official death rates were often lowered by pardoning inmates who were near death. Id. 
severe punishment. ${ }^{20}$ Prisons allowed legislatures to proportion criminal penalties, increasing the term of incarceration with each additional unheeded lesson. When it opened its penitentiary in 1817, Massachusetts, for example, amended its code to mandate an extra seven years for every offender with one prior conviction and life in prison for those with two prior convictions $\mathrm{s}^{21}$-one of the earlier "threestrikes-and-you're-out statutes" in the United States. ${ }^{22}$

Penitentiaries also offered hope of more effective identification of prior offenders. A single state list replaced decentralized county conviction records and included descriptions of marks, scars, or tattoos on each prisoner's body. ${ }^{23}$ But these rudimentary records of the bodies entering and leaving prisons were still organized only by name. It was not possible to look up a person by a missing toe or unusual scar. Moreover, as Alexis de Tocqueville reported after observing these early penitentiaries, identification was possible only if an offender was returned to prison in the same state. ${ }^{24}$ Judges were aware that many "first offenders" were actually repeat offenders, whose true identities might, or might not, be revealed later when someone recognized them in prison. As de Tocqueville concluded, noting how easily a person could pass from state to state, "the courts condemn, almost always, without knowing the true name of the criminal, and still less his previous life."25

20. Rand v. Commonwealth, 50 Va. ( 9 Gratt.) $738,747-48$ (1852) ("[T] he mischief was a want of reformation ... the legislature intended that the culprit should first hear the monitory voice of the law before the heavier doom should be announced ....").

21. Commonwealth v. Phillips, 28 Mass. (11 Pick.) 28, 31-32 (1831) (describing statute of 1818); PraTT, supra note 7, at 9. Virginia had a similar scheme. L. L. C., Jr. \& T. G. L., supra note 12, at 598-99 (describing revised code of 1819 with graded enhancements).

22. Other states during this period passed laws punishing second-time thieves more severely. See, e.g., Stevens v. People, 1 Hill 261, 262-63 (N.Y. Sup. Ct. 1841). In England, this sort of law was not used until the usual means of ridding the country of the unwanted convicted criminals - deportation to the British colonies, including Australia-was phased out in 1869 . See COLE, supra note 7 , at 18.

23. COLE, supra note 7, at 10-11; ROBERTS, supra note 1 , at 6 .

24. COLE, supra note 7, at 17 ("'If ... a delivered convict commits a new crime under a fictitious name, he can very easily conceal his relapse, providing he is not brought back to the prison where he underwent his first punishment.... [T] here is no central power to which the police officers might refer to obtain information respecting the previous life of an indicted person ...."' (quoting G. DE BEAUMONT \& A. DE TOCQUEVILLE, ON THE PENITENTIARY SYSTEM IN THE UNITED STATES, AND ITS APPLICATION IN FRANCE 72 (Francis Leiber trans., S. Ill. Univ. Press 1964) (1833))).

25. See Wayne A. Logan, Policing Identity, 92 B. U. L. REv. 1561, 1564 (2012) (quoting BEAUMONT \& DE TOCQUEVILLE, supra note 24, at 101-02); COLE, supra note 7, at 17. 
Legislatures recognized this too, and a few states in the early 1800 s changed their laws to address it. At the end of the eighteenth century, every state followed the established common law rule: any prior conviction that would boost the sentence had to be alleged in the indictment and proven to a jury beyond a reasonable doubt. ${ }^{26}$ But when the Massachusetts legislature learned that supposed first offenders were being recognized as former inmates when they arrived at the new penitentiary, it passed a statute that provided an alternative to the common law rule. Whenever the warden recognized a person as a prior offender, he had to notify the state's attorney, who in turn had to charge the prisoner as a repeat offender in a supplemental charging document called an information. ${ }^{27}$ The prisoner would then be brought from prison back to court. If his past conviction was admitted or proven to a new jury beyond a reasonable doubt ${ }^{28}$ he would be sentenced to the punishment mandated for second offenders (seven years) or third offenders (life), as the case may be. ${ }^{29}$ Through the nineteenth century, most states continued to require the prosecutor to allege in the indictment any former convictions that would increase an offender's sentence and prove those convictions along with the charge. ${ }^{30}$ But a handful of states adopted processes similar to that in Massachusetts, so that when an alias was exposed at the penitentiary, the sentence of the newly identified defendant could be increased. ${ }^{31}$

As cities grew during the Industrial Revolution, crime was increasingly blamed on a small class of repeat or "habitual" offenders, ${ }^{32}$ considered biologically inferior to normal, law-abiding citizens. Phrenologists and craniologists attempted to identify the physical manifestations of criminality, scientists searched for its biological

26. See infra notes $140,144-47$.

27. See Plumbly v. Commonwealth, 43 Mass. (2 Met.) 413, 415 (1841); In re Ross, 19 Mass. (2 Pick.) 165, 183 (1824).

28. E.g., Commonwealth v. Briggs, 22 Mass. (5 Pick.) 429, 438 (1827) ("No presumptions are to be made against the prisoner. The government must prove every essential allegation.").

29. Plumbly, 43 Mass. (2 Met.) at 416-17; In re Ross, 19 Mass. (2 Pick.) at 167 ; see also Commonwealth v. Phillips, 28 Mass. (11 Pick.) 28, 34 (1831) ("This proceeding by information to award additional punishment where sentence has already been pronounced, is founded solely on statute, is not known at the common law, is in a high degree penal, and therefore is not to be extended by construction beyond the cases clearly contemplated by the statute.").

30. See infra notes $140,143-44$.

31. See infra note 140 .

32. COLE, supra note 7 , at 10-15 (noting that this belief was encouraged by crime statistics, which began to appear in the $1820 \mathrm{~s}$ ).

33. Id. at 13. 
causes, ${ }^{34}$ and legislatures expanded punishment for repeat offenders. ${ }^{35}$ Yet, as the U.S. Civil War ended, courts still had no practical, reliable way to determine who had been convicted before. ${ }^{36}$ Criminal identification continued to depend upon personal recognition by sheriffs, prosecutors, judges, and wardens. ${ }^{37}$

\section{Technology to the Rescue-Photos, Bertillonage, and Fingerprints- 1880-1930}

By 1930, identification of past offenders had completely changed. Photography began the transformation. The very first "rogues gallery" was displayed at the New York Police Department, with 450 ambrotypes in that collection by 1858 . Photography became more accessible in the 1870 s and 1880 s, and by the late nineteenth century, police departments all over the world had a gallery, or registry, of photographs of the faces of past offenders associated with various names. ${ }^{38}$ But there remained no efficient way to search hundreds of photographs.

This problem was solved by a revolutionary system of identification invented in France by Alfonse Bertillon. ${ }^{39}$ Using an index of eleven bodily measurements rather than names, the Bertillon system identified a prisoner in minutes. It won over the wardens in New York and Illinois, who mandated measurements for all inmates by the $1890 \mathrm{~s}^{40}$ Prisons and police departments in other states followed suit.

Fingerprinting was not far behind. In the 1880s, immigration authorities in California used it to identify Chinese immigrants who had been granted return certificates, but not until 1904 was it introduced to law enforcement to supplement or replace the Bertillon system.

34. Id. at 15.

35. E.g., State v. Wilbor, 1 R.I. 199, 199-200 (1846) (discussing an 1844 statute). States that had formerly punished as recidivists those who had been to their own state's penitentiary expanded their laws to reach those who had been convicted of felonies in other states. E.g., Rand v. Commonwealth, 50 Va. (9 Gratt.) 738, 740-41 (1852).

36. For a while, officials in Britain attempted to maintain a national "Distinctive Marks Register," an index of scars and other marks, but it would take a clerk between ten and ninety hours to identify a person using the cumbersome process, which required first looking up the mark by body part, then by type of mark, then by location on the body part, and so on. However, by 1877 , the register only applied to individuals identified as habitual criminals through other means because it became too expensive to maintain. COLE, supra note 7, at 27.

37. Id. at 10-11.

38. Id. at 22 .

39. Id. at 32 .

40. Id. at 53,55 . 
Fingerprinting was first used in criminal cases in New York City for women, as Bertillon operators reportedly found it awkward to measure the body parts of prostitutes. Once fingerprinting was extended to men in $1913,{ }^{41}$ within four years the Magistrates' Court of New York City reportedly identified 31,000 individuals. ${ }^{42}$ Gradually, fingerprinting replaced Bertillonage so that by the end of the 1930s fingerprinting was the dominant method for identification. ${ }^{43}$

\section{Parole and Probation for Some, Incapacitation for the Dangerous- 1890-1970}

The new means of identifying repeat criminals reinforced the belief that a small group of offenders committed most crime. "Instinctive criminals," it was argued in 1891, could be identified by their "ill-shaped heads"; "asymmetrical faces"; "deformed,... ill-developed bodies"; "abnormal conditions of the genital organs"; "large, heavy jaws"; "outstanding ears"; and "a restless, animal-like, or brutal expression." "Criminal anthropologists" asserted that recidivists were "smaller in stature with longer and broader heads," with "furtive restless eyes," and that a primary cause of recidivism is "physical and mental degeneracy of the hereditary and acquired types." ${ }^{\text {"46 }}$ Many thought they should be segregated from society like the criminally insane. ${ }^{47}$ Eventually, sixteen states passed laws authorizing the sterilization of habitual criminals, ${ }^{48} \mathrm{a}$

41. Id. at $155-58$.

42. People v. Sallow, 165 N.Y.S. 915, 918 (N.Y. Gen. Term 1917) (citing FINGER PRINT Bureau, RePORT OF Alfred A. HART, in ANNUAL REPORT, City Magistrates' COURTS, CITY OF NEW YORK 102, 103 (1915)).

43. COLE, supra note 7, at 32, 229-32 (noting that Bertillonage was still in use in the 1930s); see also Kelley v. State, 185 N.E. 453, 456 (Ind. 1933) (noting testimony by Bertillon expert).

44. COLE, supra note 7, at 29.

45. S.A.K. STRAHAN, InSTINCTIVE CRIMINALITY: ITS TRUE CHARACTER AND RATIONAL TREATMENT 189 (John Bale \& Sons 1891).

46. J.F. SUTHERland, RECIDIVISM: Habitual CRIMINAlity, AND Habitual PETTY DELINQUENCY 59 (1908); see also COLE, supra note 7, at 26 (discussing attempts to create a composite face of known criminals, an effort that Cole says "became a crude pretext for prejudices, such as the association of criminality with ... Eastern and Southern Europeans, Jews, Gypsies and others who simply looked lower class"); WALKER, supra note 7, at 113 (noting that Americans saw the immigrants as bringing more crime in the early 1900s).

47. L. L. C., Jr. \& T. G. L., supra note 12 , at 600 \& nn.25-26.

48. PRATT, supra note 7, at 49-50 ("For the proponents of eugenics, mere exclusion from the rest of society for life as a punishment for the habituals was not enough: they should also be denied any opportunity for reproducing their kind to prevent a continuation of their diseased lineage... [S]terilisation was introduced to the penal programme in sixteen State jurisdictions in the United States."). 
practice not struck down by the U.S. Supreme Court until 1942." Leading scholars such as Norval Morris considered the eugenics effect of protracted detention of habitual criminals "possibly scientifically fruitful.",50

The new identification techniques also reassured legislatures that penalties for recidivists would no longer be applied arbitrarily, that is, only to those whose attempts to hide their pasts happened to fail. ${ }^{\text {si }}$ Recidivist statutes flourished in the 1890s and early decades of the twentieth century. ${ }^{52}$ For example, anyone convicted in New York ${ }^{53}$ or Missouri $^{54}$ of a felony with a life sentence as the possible maximum got life as the mandatory sentence if he had been previously convicted of a felony or petit theft. Some laws targeted those who committed particular offenses, such as second-time gamblers, ${ }^{55}$ thieves, ${ }^{56}$ drug possessors, $^{57}$ or liquor sellers. ${ }^{58}$ By 1930 , Congress had passed a law

49. Skinner v. Oklahoma, 316 U.S. 535, 538 (1942). See generally PAUL A. LOMBARDO, THREe Generations, No IMBECILES: EugENICS, THE SuPREME COURT, AND BUCK $V$. BELL (2008); VICTORIA F. NOURSE, IN RECKLESS HANDS: SKINNER V. OKLAHOMA AND THE NEAR TRIUMPH OF AMERICAN EUGENICS (2008).

50. NORVAl MORRIS, THE Habitual CRIMINAL 22, 24 n.2 (1951) (citing HeRmanN MANNHEIM, CRIMINAL JUSTICE AND SOCIAL RECONSTRUCTION 226-37 (Karl Mannheim ed., 1st ed. 1946)).

51. COLE, supra note 7 , at 5 .

52. PRATT, supra note 7, at 35 (noting that "recidivist statutes reached the zenith of their popularity... in the late 1920 s" and 1930 s just as fingerprinting was becoming routine (quoting George K. Brown, Note, The Treatment of the Recidivist in the United States, 23 CAN. B. REV. 640, 642 (1945)) (internal quotation marks omitted)); see also In re Miller, 68 N.W. 990, 990 (Mich. 1896) (describing a statute limiting "good time" for second offenders); Blackburn v. State, 36 N.E. 18, 20 (Ohio 1893) (describing Section 2 of an act that passed the Ohio legislature on May 4, 1885, which mandated life sentences for third-time offenders).

53. Carlesi v. New York, 233 U.S. 51, 55-56 (1914); PRATT, supra note 7, at 35 (describing a 1907 law in New York). 1893)

54. See Moore v. Missouri, 159 U.S. 673, 676 (1895); State v. Austin, 21 S.W. 31, 32 (Mo.

55. E.g., Wolf v. State, 206 S.W. 39 (Ark. 1918) (discussing how Act 55, of the Acts of 1907, punished the second offense for betting on horses more severely).

56. E.g., State v. Jones, 128 F. 626, 627 (S.D. Iowa 1904) (describing an 1898 act); In re Boggs, 45 F. 475, 475 (C.C.D. Ky. 1891) (providing that third-time larceny carried life sentence); Kelley v. People, 4 N.E. 644, 644-45 (Ill. 1886) (describing an 1883 act); Evans v. State, 50 N.E. 820,820 (Ind. 1898) (describing an 1894 act); State v. Loehr, 5 S.W. 696, 696 (Mo. 1887).

57. People v. Mock Don Yuen, 227 P. 948, 949 (Cal. Dist. Ct. App. 1924) (narcotics).

58. Banas v. People, 211 P. 367,367 (Colo. 1922); State v. Watson, 142 P. 956,956 (Kan. 1914); State v. Adams, 132 P. 171, 172 (Kan. 1913); see also Cross v. State, 78 Ala. 430, 432 (1885) (describing a statute that punished a second conviction for the offense of living in adultery with the same person with a more-severe penalty). 
punishing Prohibition violators more severely for subsequent offenses, ${ }^{59}$ and twenty-three states had passed new habitual offender laws, many providing for a mandatory life sentence for the third or fourth felony conviction. ${ }^{60}$

Lawmakers also developed a particular interest in the dangerousness of sexual offenders, and twenty-six states introduced laws authorizing lifetime imprisonment of those adjudged to be "sexual psychopaths." By 1949, thirty-two states had established criminal identification bureaus, and the number of states with habitual felony offender statutes had grown to forty-three-five of these states mandated life for the third offense, ten for the fourth offense, and another ten permitted the judge discretion to sentence a third or fourth striker to life in prison. ${ }^{62}$

The new identification techniques facilitated greater leniency as well as severity. By convincing legislators that corrections officials and judges could sort first offenders more likely to be rehabilitated from hardened criminals, improvements in criminal identification enabled new statutes authorizing release on conditions and the beginning of probation and parole. ${ }^{63}$

59. United States v. Lindquist, 285 F. 447 (W.D. Wash. 1921) (discussing the National Prohibition Act, which prescribed a greater punishment for "a second or subsequent offense" and provided that the prosecuting officer shall "plead the prior conviction"). This was not the first federal repeat-offender provision. Congress imposed a mandatory minimum of twentyfive years in prison for second-time mail thieves in 1909. Comp. Stat. 1449, $\$ 197$ (John A. Mallory) (Supp. 1909).

60. Cole, supra note 7, at 217; L. L. C., Jr. \& T. G. L., supra note 12, at 599 n.17; see also PRATT, supra note 7, at 35 (quoting Brown, supra note 52, at 640,640-83).

61. PratT, supra note 7, at 70, 93-95 (citing Alan H. Swanson, Sexual Psychopath Statutes: Summary and Analysis, 51 J. CRIM. L., CRIMINOlOGY, \& POLICE SCI. 215, 215-27 (1960)) (stating that "homosexuality, psychopathy and paedophilia were likely to be conflated to produce the image of the middle-aged sex fiend, with children as his target"). In 1937, J. Edgar Hoover penned an article titled War on the Sex Criminal, which begins with this: "[T]he sex fiend, most loathsome of all the vast army of crime, has become a threat to the safety of American childhood and womanhood." See COLE, supra note 7 (citation omitted).

62. See Paul W. Tappan, Habitual Offender Laws in the United States, 13 FED. Probation 28, 28 (1949) ("Analysis has revealed that fairly well-standardized multiple offender statutes for habitual felons exist in 43 of the 48 states ....").

63. COLE, supra note 7 , at 218 (discussing that, with increased confidence, they could provide probation or parole for novices in crime who might still be rehabilitated, and that parole began to be used for some recidivists after World War I); WALKER, supra note 7, at 118-23. 


\section{E. A Punitive Turn-Three Strikes and Other Mandatory Sentencing Laws-1970 on}

After several decades of attempts to diagnose and treat what was considered to be the disease of recidivism, ${ }^{64}$ legislators decided to rein in the discretion of judges and parole authorities and rewrote sentencing laws in every state. One of the most frequent changes was an increase in penalties for repeat offenders. ${ }^{65}$ As a dozen states and the federal government adopted judicial sentencing guidelines, commissions keyed sentences to criminal history. ${ }^{66}$ In states that retained parole, new recidivism laws included provisions denying or delaying parole eligibility for repeat offenders. ${ }^{67}$ By 1996, twenty-four states and the federal government had passed new, stricter three strikes laws. ${ }^{68}$ In some states, such as California and Washington, these laws were enacted by ballot initiative. $^{69}$ California's law provided that anyone with a first-strike offense on his record must receive a doubled prison sentence for a

64. E.g., FRIEDman, supra note 18, at 160; Alastair W. MACLEOD, RECIDIVISM: A DEFICIENCY DISEASE (1965).

65. COLE, supra note 7, at 217-18; Christopher T. Link \& Neal Shover, The Origins of Criminal Sentencing Reforms, 3 JUST. Q. 329, 334 (1986).

66. Tonry, supra note 2, at 3-4 (discussing parole guidelines using "salient factors" that predict recidivism adopted by U.S. Parole Commission and several other states).

67. For example, Florida in 1988 denied parole eligibility for the first fifteen years of imprisonment to habitual violent felony offenders. See 1988 Fla. Laws 708 (amending Fla. Stat. $\$ 775.084(4)(\mathrm{b}) 1(1988))$.

68. John Clark, JAMES Austin \& D. Alan HenRy, NAT'L Inst. Of JustiCE, “THREE STRIKES AND YOU'RE OUT": A REVIEW OF STATE LEGISLATION 1 (1997) (twentyfour states enacted three strikes laws between 1993 and 1995); Ely Aharonson, Determinate Sentencing and American Exceptionalism: The Underpinnings and Effects of Cross-National Differences in the Regulation of Sentencing Discretion, 76 LAW \& CONTEMP. PROBS. 161, 166 (2013) (noting Congress created a range of fiscal incentives for states to enact three strikes laws); COLE, supra note 7, at 223; Michael Tonry, Penal Developments in America, in PENAL REFORM IN OVERCROWDED TIMES 20 (Michael Tonry ed., 2001); see also Michael Tonry, Sentencing in America, 1975-2025, at 24 (Univ, of Minn. Law Sch. Legal Studies Research Paper Series, Working Paper No. 13-44, 2013) (noting that the laws mandating at least twenty-five years have a "sleeper effect"-those first sentenced under them are still serving their twenty-five-year terms). Alaska added its three strikes law a decade later in 2006. See Tonry, Sentencing in America 1975-2025, supra, at $11 \mathrm{n} .5$ (citing Elsa Y. Chen, Impacts of "Three Strikes and You're Out" on Crime Trends in California and Throughout the United States, 24 J. CONTEMP. CRIM. JUST. 345, 349 (2008)).

69. VANESSA BARKER, THE POLITICS OF IMPRISONMENT: HOW THE DEMOCRATIC PROCESS SHAPES THE WAY AMERICA PUNISHES OFFENDERS 118 (2009); FRANKLIN E. ZIMRING, GORDON HAWKINS \& SAM KAMIN, PUNISHMENT AND DEMOCRACY: THREE STRIKES AND YOU'RE OUT IN CALIFORNIA 11 (2001); Aharonson, supra note 68, at 176-77; Robert Heglin, A Flurry of Recidivist Legislation Means: "Three Strikes and You're Out," 20 J. LEGIS. 213, 222 (1994). 
subsequent conviction and anyone with two priors must be sentenced to a term of twenty-five years to life for a third felony offense. ${ }^{70}$

The effects of these laws have varied by state. In most, repeatoffender sentences are uncommon. ${ }^{71}$ But in Washington State as of last year, nearly $70 \%$ of the 637 prisoners serving life-without-parole sentences were sentenced under the state's three strikes law. ${ }^{72}$ In California, where a second strike carries a doubled sentence and the third strike carries twenty-five years to life, the effect was huge: maximum sentences statewide grew $6 \%$ longer, and the odds of a prison sentence rose by nearly $23 \% .^{73}$ As of 2009 , one of every four state prisoners in California was serving a second- or third-strike sentence, ${ }^{74}$ and of these, $55 \%$ were convicted of a nonviolent offense. ${ }^{75}$ Florida and

70. CAL. DEP'T OF CORR. \& REHAB., SECOND AND THIRD STRIKER FELONS IN THE ADULT INSTITUTION POPULATION (2012).

71. Chen, supra note $68,345,350-51$ (compiling the results of telephone and e-mail interviews with state criminal justice authorities conducted in the fall of 2006 to determine the frequency of use of two and three strikes provisions and noting every state other than California reported fewer than 400 second- and third-strike convictions since passage; with Washington, Nevada, South Carolina, and Virginia reporting more than 300; Pennsylvania, Arkansas, Wisconsin, New Jersey, Vermont, Maryland, Florida, Alaska, and Connecticut reporting rare use (just a few prisoners total or up to a dozen at most per year); and Montana and Utah reporting their laws have never been used); Yan Zhang, Christopher D. Maxwell \& Michael S. Vaughn, The Impact of State Sentencing Policies on the U.S. Prison Population, 37 J. CRIM. JUST. 190, 197 (2009) (noting studies of the explosion in prison population between early 1970 s and 2000 found three-strikes laws "had little national impact because few offenders outside of California, Florida, and Georgia were ever sentenced under [these] provision[s]" (citing Walter J. Dickey \& Pam Hollenhorst, Three-Strikes Laws: Five Years Later, CORR. MGMT. Q., Summer 1999, at 1-8; VINCENT SCHIRALDI ET AL., JUSTICE POLICY INST., THREE STRIKES AND YOU'RE OUT: AN EXAMINATION OF THE IMPACT OF 3-STRIKE LAWS 10 YEARS AFTER THEIR ENACTMENT 4-5 (2004))).

72. THE SENTENCING PROJECT, LIFE GOES ON: THE Historic RISE IN LIFE SENTENCES IN AMERICA 16 (2013), available at http://sentencingproject.org/doc/publications/ inc_Life \%20Goes\%200n\%202013.pdf.

73. John R. Sutton, Symbol and Substance: Effects of California's Three Strikes Law on Felony Sentencing, 47 LAW \& SOC'Y REV. 37, 66 (2013).

74. Caldwell, supra note 4, at 589 n.44 (citing CAL. DEP'T OF CORR. \& REHAB., INMATES SENTENCED UNDER THE THREE STRIKES LAW AND A SMALL NUMBER OF INMATES RECEIVING SPECIALTY HEALTH CARE REPRESENT SIGNIFICANT COSTS 1 (2010)); see also CAL. DEP'T OF CORR. \& REHAB., SECOND AND THIRD STRIKE FElONS IN THE ADULT INSTITUTION POPULATION tbls.1, 6 (showing 42,417 prisoners in California were serving second- and third-strike sentences, 1,900 of the inmates were over sixty years old, 6,000 of the offenses were drug crimes, and 11,000 of the offenses were property crimes).

75. See THE SENTENCING PROJECT, supra note 72, at 16. Also, from 1999 to 2012, the number of LWOP sentences doubled, and the percentage of LWOP prisoners sentenced under California's three strikes law grew from $7 \%$ to $68 \%$. Id. 
Georgia also saw large numbers of people incarcerated under their three strike laws. $^{76}$

Today this background sets the stage for two of the challenges that repeat-offender penalties pose for courts and legislatures. First is the escalating attack on the recidivist premiums as miscalibrated and unjustified given the purposes of punishment. The other is the questionable constitutionality of the process many jurisdictions use to impose longer sentences for offenders with prior convictions.

\section{JUSTIFYING AND CALIBRATING PENALTIES FOR REPEAT OFFENDERS: THE MISMATCH BETWEEN THEORY, RESEARCH, AND PRACTICE}

Repeat-offender penalties-as applied-too often fail to accomplish their intended purposes, and these penalties may carry unanticipated costs. Exactly which aims of criminal punishment these penalties should promote is a question that continues to generate debate, with advocates falling into one of two camps. On one side are consequentialists who believe additional punishment is warranted if it deters future crime or incapacitates the dangerous. On the other side are retributivists who believe such punishment is legitimate only if it reflects increased culpability. ${ }^{7}$ But even if a legislature could decide which theory it cares about most, ${ }^{78}$ repeat-offender penalties are poorly designed to achieve either.

\section{A. Deterrence: Weak Effects}

Proponents of repeat-offender provisions have argued that escalating penalties deter convicted offenders from committing additional crimes. ${ }^{79}$ Yet research testing this hypothesis shows that

76. Caldwell, supra note 4, at 629 n.288 (citing SCHIRALDI ET AL., supra note 71, at 4).

77. ROBERTS, supra note 1 , at 29. Rehabilitation is also a potential basis for more lenient sentences for first offenders but is difficult to reconcile with "harsher or more intrusive sentences each time the offender is reconvicted" and, in any event, appears much less important to policymakers than deterrence and incapacitation in discussions of this topic. Id. at 36.

78. Id. at ch. 8 (noting that public opinion and legislative statements seem to support both theories-desert and dangerousness; both believe in a greater probability of future offending and greater culpability).

79. E.g., Pennsylvania ex rel. Sullivan v. Ashe, 302 U.S. 51, 54-55 (1937) (explaining that "[p]ersistence in crime and failure of earlier discipline effectively to deter or reform justify more drastic treatment" is analogous to the interest in punishing those who escape with sanctions keyed to the sentence they were serving when they escaped); Estella Baker \& Andrew Ashworth, The Role of Previous Convictions in England and Wales, in Roberts \& 
repeat-offender provisions have had only weak success, if any, in deterring crime. $^{80}$ Such laws appear to be associated with a small decrease in robbery, burglary, car theft, and larceny consistent across multiple states but have had no detectable impact at all on crime in some states, such as California, where they have been used most aggressively. ${ }^{81}$ As one scholar put it in a recent review, the results of attempts to test the individual deterrent effects of incarceration are "rather bleak; the majority of studies have found that incarceration has either no effect or undesirable effects on subsequent offending,"

von Hirsch, supra note 2, at 185 (noting that the public believes punishment has greater deterrent value than is supported by research); PRATT, supra note 7, at 10 (describing a late nineteenth century justification, "[F]or those that repeated their crimes, additional quantities of it would be necessary to act as a deterrent where lesser amounts had hitherto proved to be ineffective").

80. Lila Kazemian, Assessing the Impact of a Recidivist Sentencing Premium on Crime and Recidivism Rates, in Roberts \& von Hirsch, supra note 2, at 227, 242-44 (collecting studies and noting that "[v]arious studies have demonstrated the negligible (or even detrimental) effects of three-strikes laws on crime rates, despite substantial increase in costs" (citations omitted)); Michael Vitiello, Three Strikes: Can We Return to Rationality?, 87 J. CRIM. L. \& CRIMINOLOGY 395, 446 (1997) (finding that California's three strikes law did not appear to affect the juvenile crime rate); Tonry, supra note 68 , at 39 (collecting authority and noting that "[m]ost credible empirical assessments of California's three-strikes law's effects on crime rates and patterns have concluded that none can be shown," except a few-using the methodology Tonry critiques-that found a small effect).

Incarceration generally has been shown to have little effect on crime rates although the studies are conflicting. Compare ROBERTS, supra note 1, at 33 (noting studies that find little relationship between punishment severity and aggregate crime rates), and Tonry, supra note 68, at 36-39 (arguing that government reviews and scholarship have rebutted claims of general deterrence, including Pratt et al.'s 2006 finding of no significant effects and Durlauf and Nagin's 2011 finding that at best there is only a modest deterrent effect from increases in severity of punishment and that effects of imprisonment "might on average be criminogenic rather than crime-preventative" (citing Travis C. Pratt et al., The Empirical Status of Deterrence Theory: $A$ Meta-Analysis, in TAKING STOCK: THE STATUS OF CRIMINOLOGICAL THEORY 367, 379 (Francis T. Cullen et al. eds., 2006); Steven N. Durlauf \& Daniel S. Nagin, Imprisonment and Crime: Can Both Be Reduced?, 10 CRIMINOLOGY \& PUB. POL'Y 13, 31 (2011))), and MODEL PeNAl CODE: SENTENCING \$1.02(2) cmt. e, at 34 (Tentative Draft No. $12007)$ ("The feasibility of general deterrence through marginal increases in the severity of criminal punishments is in doubt, at least for many species of criminal behavior."), with Kazemian, supra, at 238-40 (collecting studies finding some short-term decreases in aggregate crime rates following increased incarceration rates).

81. ZIMRING ET AL., supra note 69, at 93-105 (finding only weak evidence of marginal deterrence on third strikers and no hint of any decline on second strikers); Chen, supra note 68, at 362-63 (finding laws associated with "accelerated rates of decline for robbery, burglary, larceny-theft, and motor vehicle theft" in conjunction with data on the relatively few inmates incarcerated under three strikes policies in most states, suggesting that any crime reduction associated with the presence of three strikes laws outside California should probably be attributed to deterrence effects rather than incarceration effects, and concluding that narrowly constructed and seldom-used laws may be as effective as broader laws). 
although she did note that the limitations of existing research are too substantial to draw firm conclusions. ${ }^{82}$

One drawback of this research, for example, is the difficulty of accounting for variables that have been shown to influence recidivism rates, such as the type and quality of supervision after release and other correctional policies and practices that continue to change and evolve. ${ }^{83}$ As another researcher concluded: "The causes and correlates of rises and declines in crime rates are numerous, diverse, and elusive ... . [P]olicy makers must keep in mind that even major changes in sentencing policy may result in only modest impacts on crime rates." ${ }^{84}$ Additional explanations offered by researchers for the failure of repeatoffender sentences to reduce crime include: the general lack of knowledge about sentencing law; ${ }^{85}$ the criminogenic effects of prison terms $;{ }^{86}$ population constraints that require the release of inmates who are more likely to recidivate in order to make room for three strikers who are nonviolent or already in the process of "aging out" of crime ${ }^{87}$ and incarceration's tendency to increase other risk factors for crime such as social disorder and the dissolution of families. ${ }^{88}$

\section{B. Incapacitating the Dangerous: Predicting Risk from Criminal History}

A second more commonly voiced rationale for recidivist penalties is the incapacitation of those most likely to commit future crime. It is this theory that has most consistently motivated increased punishment for repeat criminals in earlier eras, as lawmakers have attempted to lock up

82. Kazemian, supra note 80 , at $240,242$.

83. E.g., Michael Ostermann, Recidivism and the Propensity to Forgo Parole Release, 29 JusT. Q. 596, 596-97 (2012); James A. Wilson, Bad Behavior or Bad Policy? An Examination of Tennessee Release Cohorts, 1993-2001, 4 CRIMINOLOGY \& PUB. POL'Y 485, 485-86 (2005).

84. Chen, supra note 68 , at 363 .

85. ROBERTS, supra note 1 , at 32 (noting "low rates of awareness of sentencing provisions, even for common or well-publicized offenses such as dr[unk] driving").

86. Kazemian, supra note 80, at 239.

87. Chen, supra note 68, at 360; Kazemian, supra note 80, at 243.

88. Kazemian, supra note 80 , at 239 ; see also RICHARD S. FRASE, JUST SENTENCING: PRINCIPLES AND PROCEDURES FOR A WORKABLE SYSTEM 189 (2013) (citing Kazemian, supra note 80; Alfred Blumstein \& Kiminori Nakamura, Processes of Redemption Should be Built into the Use of Criminal-History Records for Background Checking, in Contemporary Issues in Criminal Justice Policy: Policy Proposals from the AMERICAN SOCIETY OF CRIMINOLOGY CONFERENCE 37 (Natasha A. Frost et al. eds., 2010) (noting that existing criminal history formulas are likely "overpredicting offender risk by failing to account for such factors as nonrecency, aging effects, other changes in the offender's circumstances, substantial periods of desistance, and trends toward desistance"). 
those perceived to be dangerous recidivists. ${ }^{89}$ Parole authorities have for many decades used risk assessment and predictions of dangerousness to decide when to release an offender on parole and to select conditions of release. Only recently have these so-called evidence-based methods been embraced by judges and legislators as tools for initial sentencing. Supporters of "smart," or evidence-based sentencing, hope that calibrating sentences based upon risk will allow states to trim prison populations while getting the most bang for their criminal justice buck. ${ }^{90}$

In some jurisdictions, risk scores are formally incorporated into sentencing statutes or guidelines. ${ }^{91}$ In Virginia, risk scores determine who is eligible for alternative punishment. ${ }^{92}$ In Missouri, judges rely on an automated recommendation reporting the offender's risk score and predicted recidivism after two years for offenders in his specific risk category. ${ }^{93}$ Kentucky and Indiana include risk assessments in

89. See supra notes 31-34, $43-49$ and accompanying text; see also MODEL PENAL CODE: SENTENCING $\S 6 \mathrm{~B} .09$ discussion at 24-25 (Discussion Draft No. 3, 2010) ("Recidivism risk ... is the primary utilitarian justification for the heavy emphasis usually placed on criminal history as a sentencing factor."); ROBERTS, supra note 1, at 15.

90. COUNCIL OF STATE GOV'TS JUSTICE CTR., LESSONS FROM THE STATES: REDUCING RECIDIVISM AND CURBING CORRECTIONS COSTS THROUgh JUSTICE REINVESTMENT 4 (2013) (noting that "many states fail to focus their incarceration ... on the people most likely to commit future crimes" and advocate for the use of risk assessment instruments); ROBERTS, supra note 1 , at 21 (noting that "risk is privileged above other considerations at sentencing"); Kelly Hannah-Moffat, Actuarial Sentencing: An "Unsettled" Proposition, 30 JUST. Q. 270, 271 (2013) (noting a similar trend).

91. Guidelines incorporating higher penalties for prior offenders are sometimes at least initially based on risk assessment instruments. See, e.g., Daniel A. Krauss, Evaluating Science Outside the Trial Box: Applying Daubert to the Federal Sentencing Guidelines' Criminal History Score, 29 INT'L J.L. \& PSYCHIATRY 289 (2006); U.S. SENTENCING COMM'N, MEASURING RECIDIVISM: THE CRIMINAL HISTORY COMPUTATION OF THE FEDERAL GUIDELINES-A COMPONENT OF THE FIFTEEN YEAR REPORT ON THE U.S. SENTENCING COMMISSION'S LEGISLATIVE MANDATE 1 (2004) [hereinafter MEASURING RECIDIVISM]; Richard S. Frase, State Sentencing Guidelines: Diversity, Consensus, and Unresolved Policy Issues, 105 COLUM. L. REV. 1190, 1201 (2005).

92. MODEL PENAL CODE: SENTENCING § 6B.09 reporter's note d at 52 (Tentative Draft No. 2, 2011); BRIAN J. OSTROM ET AL., THE NAT'L CTR FOR STATE COURTS \& THE VA. CRIMINAL SENTENCING COMM'N, OFFENDER RISK ASSESSMENT IN VIRGINIA: A THREEStage Evaluation 48 (2002); Brian Netter, Using Group Statistics to Sentence Individual Criminals: An Ethical and Statistical Critique of the Virginia Risk Assessment Program, 97 J. CRIM. L. \& CRIMINOLOGY 699, 699 (2007).

93. MODEL PENAL CODE: SENTENCING $§ 6$ B.09 reporter's note i at 61 (Tentative Draft No. 2, 2011); Michael A. Wolff, Evidence-Based Judicial Discretion: Promoting Public Safety Through State Sentencing Reform, 83 N.Y.U. L. REV. 1389, 1404 (2008); Michael A. Wolff, Missouri Provides Cost of Sentences and Recidivism Data: What Does Cost Have to Do with Justice?, 24 FED. SENT'G REP. 161, 162 (2012). 
presentence reports. ${ }^{94}$ Risk assessment, one scholar noted, "is transforming the way that sentencing judges do business." ${ }^{.95}$ As an indication of how controversial this is, the leading legal periodical on sentencing, the Federal Sentencing Reporter, recently devoted an entire issue to it. ${ }^{96}$ Risk assessment at sentencing also triggered a major debate in the American Law Institute, resulting in a provision that endorses its limited use. ${ }^{97}$

Many understandably object to the use of risk prediction in sentencing as unfair: it punishes a defendant more severely just because he has the same characteristics as other people who reoffended after release, and it deprives him of liberty for what he might do rather than what he actually did. ${ }^{98}$ Although an offender's criminal history plays a prominent role in risk assessment, some critics of risk assessment are most concerned about its reliance upon factors other than prior criminal

94. See Malenchik v. State, 928 N.E.2d 564, 566 (Ind. 2010); Sonja B. Starr, EvidenceBased Sentencing and the Scientific Rationalization of Discrimination, 66 STAN. L. REV. (forthcoming 2014); see also Hannah-Moffat, supra note 90, at 272 (noting use of the risk assessment in Pennsylvania).

95. J.C. Oleson, Risk in Sentencing: Constitutionally Suspect Variables and EvidenceBased Sentencing, 64 SMU L. REV. 1329, 1394 (2011); see also Discussion of Model Penal Code: Sentencing, 88 A.L.I. PROC. 123, 133 (2011) ("[T]he use of risk to lengthen sentences is the dominant practice in the United States today." (statement of Professor Kevin Reitz)).

96. Risk Assessment: Methodologies and Application, 16 FED. SENT'G REP. 161 (2004); see also Hannah-Moffat, supra note 90, at 271 ("There is a lack of consensus about the suitability, use, and actual role played by actuarial instruments [generally] in sentencing.").

97. See Model Penal Code: Sentencing § 6B.09, at 52-53 (Tentative Draft No. 2, 2011); id. app. B at 131; MODEL PENAL CODE: SENTENCING §6B.09 discussion at 26 (Discussion Draft 2010) ("Should research-based risk and needs assessment be incorporated into sentencing guidelines and made an explicit part of the judicial sentencing process? Is the MPCS draft correct to encourage the use of actuarial risk assessment at sentencing as a prison-diversion tool, while hesitating to endorse a similar use of risk assessment as a basis for enhanced penalties?"); MODEL PENAL CODE: SENTENCING app. A at 341 (Tentative Draft No. 1, 2007) (Black-Letter Provisions Amended to Establish a System of Advisory Sentencing Guidelines); id. $\$ 6 \mathrm{~B} .07 \mathrm{cmt}$. b at $233-34$ ("There is controversy within the research community about the degree of predictive power of criminal history standing in isolation, and reason to believe that predictive accuracy varies with circumstances. There are also concerns that sentencing schemes that place heavy weight on prior offending exacerbate punishment disparities affecting racial and ethnic minority groups. Given that current knowledge on these important subjects is far from adequate, $\S 6 \mathrm{~B} .07$ leaves open the possibility that, for some, many, or all offenses, commissions of the future might decide the consideration of criminal history should be eliminated or given muted effect.").

98. RoBERTS, supra note 1, at 32; see also, e.g., Hannah-Moffat, supra note 90, at 278 (noting that "[i]nstead of understanding that an individual with a high risk score shares characteristics with an aggregate group of high-risk offenders, practitioners are likely to perceive the individual as a high risk offender," that the person "poses a greater danger to society and sentencing him/her accordingly"); Tonry, supra note 2, at 6 n.7. 
history, such as gender ${ }^{99}$ or age, over which the offender has no control. $^{100}$ Reliance upon such factors, they argue, violates the Equal Protection Clause. ${ }^{101}$ But a growing chorus is warning that even the use of criminal history to predict recidivism risk is unjustified, or counterproductive. Two of the main criticisms critique the reliability of predictions of recidivism based on past offending and the corrosive racial effects of escalating punishment for those with prior convictions.

\section{Concerns About the Reliability of Risk Predictions Based upon Criminal History}

First, even though the best risk-prediction assessments are better than expert judgment and can correctly predict the risk class of an offender as often as seven out of ten times, ${ }^{102}$ sentencing based on criminal history as practiced is not risk assessment at its best. Continuing research, testing whether criminal history predicts future criminality, does support a relationship between past and future

99. E.g., Tonry, supra note 2 (noting explicit use of gender under Virginia guidelines). Research shows that women are less likely to recidivate. See MODEL PENAL CODE §6B.09 reporter's note $\mathrm{i}$ at 61 (Tentative Draft No. 2, 2011) (collecting studies); MEASURING RECIDIVISM, supra note 91 , at 11 (reporting the results of a study that found that women recidivate at a lower rate than men, with a rate of $24.3 \%$ for men and $13.7 \%$ for women); Patrick A. Langan \& David J. LeVin, Bureau of Just. STatistics, U.S. Dep'T of JUSTICE, RECIDIVISM OF PRISONERS RELEASED IN 1994, at 7 (2002).

100. Christopher Slobogin, Proving the UnProvable: The Role of LaW, SCIENCE, AND SPECULATION IN ADJUDICATING CULPABILITY AND DANGEROUSNESS 11314 (2007) (collecting criticism of the use of factors over which an individual has little or no control). See generally Hannah-Moffat, supra note 90 (criticizing the use and reliance on noncriminal history factors in sentencing).

101. See Christopher Slobogin, Risk Assessment, in THE OXFORD HANDBOOK OF SENTENCING AND CORRECTIONS, supra note 1, at 196, 209 (noting the Council of Europe's proposal to prohibit risk assessments other than in past crimes); Starr, supra note 94.

102. MODEl PENAL CODE: SENTENCING \$6B.09 reporter's note e at 60 (Tentative Draft No. 2, 2011) ("The better risk scales can yield correct classifications, measured against actual recidivism data, in up to 70 percent of all cases ....") (collecting authority); Paul Gendreau et al., A Meta-Analysis of the Predictors of Adult Offender Recidivism: What Works!, 34 CRImINOlOGY 575, 588 (1996); Joan Petersilia \& Susan Turner, Guideline-Based Justice: Prediction and Racial Minorities, 9 CRIME \& JUST. 151, 174 (1987) (noting that the predictive power of risk assessment instruments is at best sixty to seventy percent accurate); Slobogin, supra note 101, at 209. 
offending. ${ }^{103}$ But the research also raises concerns about the reliability of predicting recidivism based on criminal history. ${ }^{104}$

Much of the research supporting the reliability of risk prediction instruments has tested instruments that were developed to predict recidivism by parolees and to select conditions of release. These instruments include variables such as age, gender, and type of offense, as well as "dynamic" factors that change after sentencing, such as treatment for substance abuse or mental health issues, physical health, job training, education, marital status, and social support. ${ }^{105}$ Predicting risk based on prior criminal history alone omits all of these factors, increasing the number of cases for which the prediction is wrong. ${ }^{106}$ There may be good reasons for omitting all factors other than criminal history from risk assessments at sentencing. However, when the only

103. MODEL PENAL CODE: SENTENCING $\S 6$ B.09 reporter's note a at 58-59 (Tentative Draft No. 2, 2011); ROBERTS, supra note 1, at 22 (noting that predictions of future felony offending are more reliable when multiple previous convictions are taken into account than when they are not); Petersilia \& Turner, supra note 102, at $166 \mathrm{n} .8$ ("Prior record has consistently been shown to be the best predictor of future criminality.").

104. Professor Kevin Reitz, Reporter for the MPC Sentencing Project, recently suggested that even if risk assessment as applied is more reliable than trained professional judgment, the false positive rate may be so high that basing the duration of a prison term on risk prediction may not be defensible. Kevin R. Reitz, The "Traditional" Indeterminate Sentencing Model, in THE OXFORD HANDBOOK OF SENTENCING AND CORRECTIONS, supra note 1, at 270, 280-81 (discussing instruments used for parole release); see also MODEL PENAL CODE: SENTENCING \& 6B.09 cmt. e at 56 (Tentative Draft No. 2, 2011) (warning of "notoriously high" error rates in predictions of future criminal behavior).

105. Paul Gendreau et al., supra note 102, at 588 (noting "variables such as age, criminal history, companions, family factors, gender, social achievement, and substance abuse are significant and potent predictors of recidivism"); John Monahan, A Jurisprudence of Risk Assessment: Forecasting Harm Among Prisoners, Predators, and Patients, 92 VA. L. REV. 391, 413-23 (2006).

106. SLOBOGIN, supra note 100 , at 105-06; Netter, supra note 92 , at 712 (noting a study that finds VCSC error rates and criticizing methodology); OSTROM ET AL., supra note 92, at 48 (observing that many assessment instruments actually used at sentencing omit age, gender, employment, and marital status); Petersilia \& Turner, supra note 102, at 167 (omitting factors that are correlated with race from a model to predict recidivism reduced the accuracy of the model by five to twelve percentage points); Slobogin, supra note 101, at 208-09, 283-84 (eliminating problematic variables and those associated with protected categories (i.e., race and gender) reduces predictive power and also noting that some studies may not include enough factors because samples are too small); Wilson, supra note 82, at 507-11 (noting postrelease variables that influence recidivism, such as a jurisdiction's policy on when violations require reincarceration, when violations are charged, and rehab/reentry policies). But see Jennifer Skeem, Risk Technology in Sentencing: Testing the Promises and Perils (Commentary on Hannah-Moffat, 2011), 30 JuST. Q. 297, 300 (2013); MODEL PENAL CODE: SENTENCING app. B at 131 (Tentative Draft No. 2, 2011) (arguing that "the predictive value of the socalled dynamic factors has yet to be demonstrated empirically"); Starr, supra note 94. 
basis for a prediction is criminal history, it is misleading to equate its accuracy with that of the best risk assessment instruments.

Also, although research confirms that recidivism rates do increase as the number of prior convictions increases beyond three or four, the relationship between a single prior conviction and future crime is much more tenuous. ${ }^{107}$ For example, two years after release from their first conviction, offenders aged forty-two or older are no more likely to commit a crime than people with clean records; for those between thirty-seven and forty-one years old, the rates converge after five years. ${ }^{108}$ So maybe the old adage "Once a criminal, always a criminal" might make sense if it was "Four times a criminal recently, probably a criminal later," but to assume that a single criminal conviction dooms a person to a life of crime may be no more accurate than nineteenth century attempts to predict future criminal behavior from jaw size.

The research confirming the relationship between past offending and recidivism also does not use a consistent measure of recidivism. Measures include any subsequent violent crime, felony arrest, felony conviction, conviction for any crime including a misdemeanor, or violation of a condition of supervised release..$^{109}$ A risk assessment instrument generally reliable in predicting re-imprisonment for any reason may not be a reliable method of forecasting the likelihood of future violent behavior. ${ }^{110}$

107. ROBERTS, supra note 1 , at $30-32$ ("[R]esearch suggests that the relationship between the number and nature of previous convictions and the likelihood of reoffending is complex and attenuates more rapidly than is commonly believed."); Shawn D. Bushway et al., The Predictive Value of Criminal Background Checks: Do Age and Criminal History Affect Time to Redemption?, 49 CRIMINOLOGY 27, 50-52 (2011) (finding a significant relationship between the number of prior offenses and the likelihood of re-offending).

108. Bushway et al., supra note 107 , at 51 .

109. Hannah-Moffat, supra note 90, at 277; JoAn PETERSilia, CAL. POLICY RESEARCH CTR., UNDERSTANDING CALIFORNIA CORRECTIONS 73-74 (2006); see also MEASURING RECIDIVISM, supra note 91, at 7 ("Supervision violations are the largest type of recidivism behavior, accounting for an average 45 percent of recidivism across the CHCs."); SLOBOGIN, supra note 100, at 112 (stating that validation may count a minor assault as well as a more serious crime); Slobogin, supra note 101, at 208 (noting that validation sometimes uses only violation acts).

110. Other variation between research and applied risk prediction includes the use of instruments validated for one population on a different population where the reliability of predictions are either not tested or not accurate. See SLOBOGIN, supra note 100, at 111; Hannah-Moffat, supra note 90, at 280 (discussing how existing instruments based on males are not applicable to women); Slobogin, supra note 101, at 208. Krauss notes that the very limited efforts to test the predictive accuracy of the CHS in USSG suffer from great variation based on the cohort of the population studied and that subjects studied differed from those actually sentenced. Krauss, supra note 91 , at 300 . Several sources, including James Bonta et 
Repeat-offender laws and criminal history scores also do not necessarily track the measures of past offending that research links to recidivism. Juvenile history is often included, ${ }^{111}$ despite research showing that most people desist from crime after late adolescence and questioning the predictive value of juvenile offenses. ${ }^{112}$ Depending upon the age of an offender, the recency of a prior conviction may dramatically impact its predictive capacity, ${ }^{113}$ yet criminal history provisions typically do not vary with the age of the defendant, nor do they always exclude prior convictions from decades earlier. ${ }^{114}$ Arrests, convictions, and sentence length are all used for assessing criminal history, but each may carry a different predictive power. ${ }^{115}$ The type of prior crime also matters. For example, property offenses are much

al., The Dangerous Offender Provisions: Are They Targeting the Right Offenders?, 40 CAN. J. CRIMINOLOGY 377, 377 (1998), observe that instruments for nonsexual offenders do not do well at predicting re-offending by sex offenders. See Markus Dirk Dubber, Note, The Unprincipled Punishment of Repeat Offenders: A Critique of California's Habitual Criminal Statute, 43 STAN. L. REV. 193, 236 (1990) (calling this defect in California's law "scientifically and morally suspect").

111. E.g., Cal. Penal Code $\$ 1170.12$ (b)(3) (West 2012); Tex. Penal Code AnN. $\S 12.42$ (f) (West Supp. 2013); see also Joseph B. Sanborn Jr., Second-Class Justice, First-Class Punishment: The Use of Juvenile Records in Sentencing Adults, 81 JUDICATURE 206, 206 (1998).

112. Reitz, supra note 104, at 280 (discussing instruments used for parole release: "Some states include arrests in the mix, while most register only convictions or past incarcerations, and there are sharp difference of opinion on the use of juvenile records"); Elizabeth S. Scott \& Thomas Grisso, The Evolution of Adolescence: A Developmental Perspective on Juvenile Justice Reform, 88 J. CRIM. L. \& CRIMINOLOGY 137, 154 (1997); BUREAU OF JUST. STATISTICS, U.S. DEP'T OF JUSTICE, PRIVACY AND JuVENILE Justice ReCORdS: A MidDECADE STATUS REPORT 2 (1997) (while "[t]he vast majority of juveniles desist from crime, ... a small minority engag[e] in chronic and serious recidivistic behavior").

113. Bushway et al., supra note 107 , at 50-52; Tonry, supra note 68 , at $42-43$ (arguing that confining people for property and violent offenses after they would have desisted from crime in late teens and early twenties is inefficient and may be criminogenic; even active career offenders end their careers in their thirties).

114. E.g., Cal. Penal Code $\S 667$ (c) (West 2012); Kan. Stat. AnN. $\$ 21-4710$ (d)(3)(8) (2006) (providing some juvenile adjudications decay, but no decay period for adult convictions); N.C. GEN. STAT. § 15A-1340.14 (2011); 204 PA. CONS. STAT. § 303.6(c) (2005) (limitations period only for juvenile history); MODEL PENAL CODE: SENTENCING § 6B.09 (Tentative Draft No. 2, 2011); Dubber, supra note 110, at 208 (noting that under California's section 667 "a 30-year-old conviction carries the same weight as a 3-month-old conviction"); Julian V. Roberts, The Role of Criminal Record in the Sentencing Process, 22 CRIME \& JUST. 303, 356 (1997) ("most systems simply count all convictions within a ten- or fifteen-year period," trading ease of application for a loss of discrimination between offenders of variable recidivism risk).

115. On the debate about whether to use arrests or noncharged conduct in criminal history, see Tonry, supra note 2 . 
more likely to be repeated than other offenses. ${ }^{116}$ But sentencing laws and rules and guidelines often do not distinguish between types of felonies. One set of guidelines equates those who solicit prostitution with those convicted of robbery or manslaughter. ${ }^{117}$ Some provisions raise penalties for those with past misdemeanors and even deferred adjudications. ${ }^{118}$ These various problems suggest that although sophisticated risk assessment instruments may generate predictions of recidivism that are right more often than they are wrong, there is little reason to expect that estimates based on prior convictions alone would be as accurate.

\section{Costs of Increasing Sentences Based on Predictions from Criminal History: Exacerbating Racial Bias}

A second problem is that even if using criminal history does help somewhat in predicting recidivism, any resulting marginal reduction in crime may not be worth its costs. Recent research has shown that reliance on criminal history exacerbates past racial bias in investigation, arrest, prosecution, and sentencing. ${ }^{19}$ Bernard Harcourt in his book

116. ROBERTS, supra note 1, at 15; EDWARD ZAMBLE \& VERNON L. QUINSEY, THE CRIMINAL RECIDIVISM PROCESS 96 (1997) (showing those whose new convictions involved only property had longer but less violent criminal histories); OSTROM ET AL., supra note 92, at 79; Tonry, supra note 2, at 4 (noting that one of the changes to the well-known risk assessment instruments on which the USSG CHS score is based that has increased the rates of false positives was removing factors that had successfully identified those less serious crimes most likely to be repeated, such as auto theft and check fraud).

117. Michael Tonry, Proportionality, Parsimony, and Interchangeability of Punishments, in WHY PUNISH? HOW MUCH? A READER ON PUNISHMENT 217, 227 (Michael Tonry ed., 2011); see also Bernard E. Harcourt, Against Prediction: Profiling, Policing, AND PUNISHING IN AN ACTUARIal AGE 100 (2007) (noting that focus is on the number of priors with little distinction made between the types of offenders).

118. E.g., 18 U.S.C. $\$ 922(\mathrm{~g})(9)$ (2012) (some misdemeanors); United States v. Morillo, 178 F.3d 18, 18, 21 (1st Cir. 1999) (holding that a "continuance without finding" disposition under Mass. Gen. Law, Ch. $278, \S 18$, counts as a prior sentence for federal sentencing purposes because it is an admission of guilt); Rudman v. Leavitt, 578 F. Supp. $2 d$ 812, 815 (D. Md. 2008) (holding that probation before judgment under Maryland law is considered a prior conviction for purposes of federal sentencing). But see MODEL PENAL CODE: SENTENCING $\$ 6.02 \mathrm{~B}(9)$ (Discussion Draft No. 4, 2012) (arguing that a deferred adjudication may not be considered a part of the accused's criminal history in later proceedings).

119. Tonry, supra note 1, at 77 ("Because black offenders are arrested more often and at younger ages than whites, they are more often affected by prior record increments."); ROBERTS, supra note 1, at 7; Alfred Blumstein \& Jacqueline Cohen, Characterizing Criminal Careers, 237 SCl. 985, 990 ("[R]acial discrimination in arrest, sentencing, or parole decisions, which is unambiguously prohibited on normative grounds, is also empirically wrong as a basis for decisions about active offenders."); Tonry, supra note 2. But compare Skeem, supra note 106, at 301 (arguing that criminal history does not raise the same race effects as other factors), with Oleson, supra note 95, at 1396. 
Against Prediction calls this the "ratchet effect" and condemns risk prediction at all phases of the criminal justice process for this reason. ${ }^{120}$ Nearly one in three adults in this country has a criminal history record, ${ }^{121}$ and as of 2007, the percentage of blacks under correctional control in the United States was more than four times that of whites. ${ }^{122}$ Professor Richard Frase found that in Minnesota two-thirds of racial disparities in imprisonment rates resulted from the weighting of criminal history factors in sentencing. ${ }^{123}$ Since California adopted its three strikes law, black defendants have received significantly longer prison sentences than whites and Latinos. ${ }^{124}$ Just a few months ago, a bill to loosen criminal history requirements for exempting federal drug offenders from mandatory minimums was introduced in Congress, and U.S. Attorney General Eric Holder ordered federal prosecutors to consider ignoring recidivism provisions, stating: "In some cases ... recidivist enhancement statutes have resulted in unduly harsh sentences and perceived or actual disparities that do not reflect our Principles of Federal Prosecution." 125

120. HARCOURT, supra note 117 , at 147.

121. See U.S. EQUAL EMP'T. OPPORTUnity COMm'N, EEOC EnForCEMENT

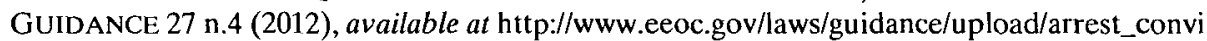
ction.pdf [hereinafter EEOC] (citing Robert Brame et al., Cumulative Prevalence of Arrest From Ages 8 to 23 in a National Sample, 129 Pediatrics 21, 25-26 (2012)).

122. Id. at 37 n.74 (citing PEW CTR. ON THE STATES, ONE IN 31: THE LONG REACH OF AMERICAN CORRECTIONS 4, at 5 (2009), available at http://www.pewcenteronthestates.org/u ploadedFiles/PSPP_1in31_report_FINAL_WEB_3-26-09.pdf); WILLIAM J. SABOL ET AL., BUREAU OF JUST. STATISTICS, U.S. DEP'T OF JUST., PRISONERS IN 2006, at 8 (2007).

123. FRASE, supra note 88, at 216; Jamie Fellner, Race and Drugs, in THE OXFORD Handbook of EThNicity, Crime, and Immigration (Sandra M. Bucerius \& Michael Tonry eds.) (2013), available at http://www.hrw.org/sites/default/files/related_material/Race\% 20 and\%20Drugs.pdf (concluding that any use of recidivist enhancements increased racial disparity, but using arrest data in particular creates greater disparity than using past sentences); see also Hannah-Moffat, supra note 90, at 277, 279, 282; Cassia Spohn et al., The Effect of Prior Record in Sentencing Research: An Examination of the Assumption that Any Measure Is Adequate, 4 JUST. Q. 287, 289 (1987) ("[M] easures of incarceration had the most uniform effects on the sentences of both blacks and whites, while other measures had opposite effects for blacks and for whites or had no strong positive associations with sentence severity."); JOHN PAWASARAT \& LOIS M. QUINN, WISCONSIN'S MASS INCARCERATION OF AFRICAN AMERICAN MALES: WORKFORCE CHALLENGES FOR 2013, at 15 (2013) ("The incarceration levels [for black men from Milwaukee County] in the 2003-2008 period are nearly four times those seen in 1990 before drug law changes, truth-in-sentencing, mandatory sentences, and three-strikes laws were broadly imposed.").

124. SCOTt Ehlers ET AL., RaCial Divide: AN EXamination OF THE IMPaCt of CALIFORNIA's THREE STRIKES LAW ON AFRICAN AMERICANS AND LATINOS 2 (2004).

125. Memorandum from the Attorney Gen. to the U.S. Attorneys and Assistant Attorney Gen. for the Criminal Div. 1, 3 (Aug. 12, 2013) (noting that a Prior Felony Information pursuant to 21 U.S.C. $\$ 851$ should not be filed "unless the defendant is involved in conduct that makes the case appropriate for severe sanctions"). 
This problem is so pronounced that the Equal Employment Opportunity Commission recently warned employers that using criminal history data in hiring decisions could expose them to disparate impact lawsuits. ${ }^{126}$

\section{Just Deserts in Proportion to Blame: A Mismatch with Repeat- Offender Penalties}

For these reasons and more, many retributivists would forbid any consideration of criminal history in setting sentences. Prior acts, they argue, are unrelated to the only thing that matters in sentencing: the blameworthiness of the offender for the offense of conviction. Some retribution purists would abandon consideration of criminal history as entirely inconsistent with these principles. ${ }^{127}$ Others committed to the sentencing philosophy of "just deserts" have argued that repeat offenders are actually more blameworthy because they are more defiant and incorrigible, ${ }^{128}$ or because they had already learned that their behavior was wrong. ${ }^{129}$

Too often current laws fail to advance either theory. To indicate defiance, an additional crime would require willful law breaking, but of course a defendant may be convicted even if he believes he is complying

126. See EEOC, supra note 121; see also John F. Pfaff, Waylaid by A Metaphor: $A$ Deeply Problematic Account of Prison Growth, 111 MICH. L. REv. 1087, 1097 (2013) (noting that although relatively few drug arrests result in incarceration, when later arrested for a nondrug offense prior drug convictions may lead to a longer sentence, or to incarceration rather than probation, and suggesting "it may be more productive for reformers [interested in reducing prison populations] to focus on changing repeat-offender laws, not drug-sentencing laws").

127. Model Penal Code: Sentencing \$6B.07 (Tentative Draft No. 1, 2007); George P. FletCher, Rethinking Criminal LAW 466 (2000) (noting that there are "serious ethical issues in punishing a person more severely on the basis of past crimes already once punished"); HARCOURT, supra note 117, at 238; ANDREW VON HIRSCH, PAST OR FuTURE CRIMES: DESERVEDNESS AND DANGEROUSNESS IN THE SENTENCING OF CRIMINALS 77-91 (1987) (arguing that only a modest increment of additional punishment for prior offenses is permissible in just-deserts theory); ROBERTS, supra note 1, at 9 (collecting proponents of what he calls "flat rate" sentencing, based only on crime of conviction and not varying with the character of the defendant); RICHARD G. SINGER, JUST DESERTS: SENTENCING BASED On EQUAlity AND DESERT 67-73 (1979); Stephen J. Morse, Preventive Confinement of Dangerous Offenders, 32 J.L. MED. \& ETHICs 56, 66 (2004).

128. ROBERTS, supra note 1, at 37; Markus Dirk Dubber, Recidivist Statutes as Arational Punishment, 43 BUFF. L. REV. 689, 705 (1995) (terming this theory a "penalty for recalcitrance" or "insufficient obsequiousness" unrelated to "moral desert"); Paul H. Robinson, Criminal Law Scholarship: Three Illusions, 2 THEORETICAL INQUIRIES L. 287, 313 (2001).

129. ROBERTS, supra note 1 , at 88 . 
with the law. ${ }^{130}$ Both of these theories of increased culpability also would logically exclude offenses that involve less than knowing behavior, yet repeat-offender premiums are imposed for negligent, impulsive, and reckless action too. ${ }^{131}$ Nor are increased sentences conditioned upon a finding that the defendant committed the same offense again. ${ }^{132}$

Most importantly, for higher penalties to make sense for repeat offenders under either of these greater-culpability theories, the latest offense must have been committed after conviction and punishment for the earlier offense. Many repeat-offender provisions punish defendants who have "prior" convictions not because their latest criminal acts were committed after a previous sentence but only because prosecutors decided to prosecute sequentially multiple counts arising from a single incident. ${ }^{133}$ Some statutes explicitly authorize repeat-offender penalties for defendants convicted of multiple offenses committed at the same time or even for defendants whose prior conviction was for an offense that was committed after the charged offense. ${ }^{134}$ In sum, legislatures, commissions, and courts could do a better job of matching actual repeatoffender punishments with both theory and research.

130. Id. at 42 .

131. Andrew von Hirsch, Proportionality and Progressive Loss of Mitigation: Further Reflections, in Roberts \& von Hirsch, supra note 2, at 1,5 ("[A] mark of much recidivism (especially repeat-minor offending) is impulsiveness."); Michacl Tonry, The Questionable Relevance of Previous Convictions to Punishments for Later Crimes, in Roberts \& von Hirsch, supra note 2, at 91.

132. Youngjae Lee, Repeat Offenders and the Question of Desert, in Roberts \& von Hirsch, supra note 2, at 49,56 .

133. Caldwell, supra note 4, at 589-90; Dubber, supra note 110, at 228-29 (criticizing this aspect of California's law); see also Reitz, supra note 2, at 143-48 (discussing the difficulty of reconciling the recidivist premium with the bulk discount).

134. FRASE, supra note 88, at 178-79; Richard S. Frase, Prior-Conviction Sentencing Enhancements: Rationales and Limits Based on Retributive and Utilitarian Proportionality Principles and Social Equality Goals, in Roberts \& von Hirsch, supra note 2, at 117, 117-19; Kenneth G. Schuler, Note, Continuing Criminal Enterprise, Conspiracy, and the Multiple Punishment Doctrine, 91 MICH. L. REv. 2220, 2228-29 nn.59-60 (1993); see also Deal v. United States, 508 U.S. 129, 135 (1993) (interpreting 18 U.S.C. \& 924(c)(1) to require only a jury finding of guilt for conviction and not that an offender commit an additional crime after another conviction); Commonwealth v. Gehris, 54 A.3d 862, 867 (Pa. 2012) (reviewing authority and interpreting statute to bar second-offender sentence when that sentence is based on other counts in a multiple-count complaint); Commonwealth v. Jarowecki, 985 A.2d 955, 968-69 (Pa. 2009) (same); Brief for Defendant-Appellant at 37, United States v. Clark, No. 12-30377 (9th Cir. Aug. 22, 2013). See generally Cynthia L. Sletto, Annotation, Chronological or Procedural Sequence of Former Convictions as Affecting Enhancement of Penalty Under Habitual Offender Statutes, 7 A.L.R.5th 263 (1992). 


\section{THE PROCESS FOR CHARGING AND PROVING PRIOR CONVICTIONS THAT RAISE SENTENCE RANGES: A CHANGING CONSTITUTIONAL LANDSCAPE}

A separate controversy is whether the process for imposing these penalties violates the Constitution. Specifically, when a statute increases the range of punishment for prior offenders above that available for first offenders, lower courts have relied upon Supreme Court precedent in holding that the prior conviction may be treated as a sentencing factor, determined only after conviction, with no formal notice, by a judge who finds it more likely than not. But this should, and likely will, change. There is no adequate justification for denying the accused his right to notice and proof beyond a reasonable doubt to a jury of the fact of prior conviction if that fact raises the range of punishment he faces. In other words, a prior conviction that aggravates the range of punishment must, like any other fact with this effect, be treated as an element of what is essentially a greater offense. This Part examines the origins, purported justifications, and probable demise of the rule that allows courts to treat prior convictions differently than any other fact triggering increased punishment.

\section{A. Apprendi v. New Jersey, Alleyne v. United States, and the Exception for Prior Convictions}

In the summer of 2000 , the Supreme Court in Apprendi v. New Jerse $^{135}$ held that a fact that increases the maximum penalty a defendant faces for a crime is an element of that crime, and a defendant has a right to have a jury find that fact beyond a reasonable doubt. A sentence longer than what is authorized for the offense of conviction, based on a judge's determination that a fact is probably true, violates the Sixth Amendment right to a jury finding of every element, said the Supreme Court. This past summer, in Alleyne v. United States, ${ }^{136}$ the Court overruled a 2002 decision in which it had refused to extend Apprendi's principle to facts that increase only the minimum sentence. Element status for facts raising a sentencing range brings with it at least three rights: the right to jury determination, the right to proof beyond a reasonable doubt, and, at least in the federal courts, the right to inclusion of the allegation in the indictment. ${ }^{137}$

135. 530 U.S. $466(2000)$.

136. 133 S. Ct. 2151 (2013).

137. See United States v. Cotton, 535 U.S. 625, 627 (2002) ("In Apprendi, we held that '[o]ther than the fact of a prior conviction, any fact that increases the penalty for a crime 
But in every one of its many decisions applying Apprendi, the Court has carefully stepped around statutes that raise punishment ranges for prior offenders. It has done this by consistently including in each declaration of the Apprendi rule an exemption for the particular fact of prior conviction. ${ }^{138}$ Yet none of the many cases stating the Apprendi rule have actually involved a recidivist penalty, so the exception remains dicta. Most recently, the Alleyne decision included a footnote explaining that the Court declined to revisit the exception because the parties had not contested it. ${ }^{139}$ Plenty of other defendants are contesting

beyond the prescribed statutory maximum must be submitted to a jury, and proved beyond a reasonable doubt.' In federal prosecutions, such facts must also be charged in the indictment." (internal citations omitted)). When applying the Apprendi rule in state cases, the Court has addressed only jury and burden issues, not charging. States have divided over whether the Sixth Amendment requires such facts to be included in the initial charge. See Wayne R. LaFave et AL., 5 CRim. Proc. § 19.3(a), § 26.4(i) n.200.9 (3d ed. 2013) (recognizing that most of the more than a dozen decisions addressing this issue have held that Apprendi facts are not elements that must be included along with the original charge under federal constitutional law, collecting authority, and noting that some argue that the notice requirement of the Sixth Amendment is satisfied by notice other than inclusion in the charging instrument, while others seem to reject the very premise of the Court's doctrine, reasoning that the different levels of punishment do not create separate offenses and that the severity of punishment for a single offense is not an appropriate subject of grand jury review); see also MODEL PENAL CODE: SENTENCING \$ 7.07B cmt. c \& reporter's note c at 301,314 (Tentative Draft No. 1, 2007) (noting that "[c]onsistent with all state legislation on the subject, $\S 7.07 \mathrm{~B}$ does not treat jury-sentencing facts as elements of offenses. The provision does assume, however, that Due Process guarantees in federal and state law will require that the defendant receive timely notice of any alleged jury-sentencing fact in the case, and must be given adequate opportunity to prepare to challenge the existence of the fact in a jury proceeding," recognizing that "many jurisdictions have adopted procedures outside of the charging instrument to ensure that the government gives adequate notice to the defendant that a jury-sentencing fact will been raised") (collecting authority).

138. See, e.g., Cunningham v. California, 549 U.S. 270, 281-82 (2007) ("Other than a prior conviction, we held in Apprendi, 'any fact that increases the penalty for a crime beyond the prescribed statutory maximum must be submitted to a jury, and proved beyond a reasonable doubt."' (internal citation omitted)); Carachuri-Rosendo v. Holder, 560 U.S. 563, 563 n.3 (2010) ("[T]he statutory scheme comports with Almendarez-Torres, in which we explained that the Constitution does not require treating recidivism as an element of the offense." (internal citations omitted)); United States v. O'Brien, 560 U.S. 218, 224, 235 (2010) (noting that "one exception has been established" and that "the recidivist provisions in [18 U.S.C. $\$ 924]$ (C)(i) and (ii) ... are typically sentencing factors"); James v. United States, 550 U.S. 192, 214 n.8 (2007) ("To the extent that James contends that the simple fact of his prior conviction was required to be found by a jury, his position is baseless. James admitted the fact of his prior conviction in his guilty plea, and in any case, we have held that prior convictions need not be treated as an element of the offense for Sixth Amendment purposes.").

139. Alleyne v. United States, 133 S. Ct. 2151, 2160 n.1 (2013) ("Because the parties do not contest that decision's vitality, we do not revisit it for purposes of our decision today."). 
it, and a majority of justices may be ready to scrap it. Here is why they should.

\section{B. No Clear Historical Basis for the Exception}

First, the historical record, so crucial to the Court in all of its Apprendi cases, does not support exempting prior convictions from the Apprendi rule. As for charging practice, in the late 1700s, there appear to be no decisions departing from the common law rule that required the initial charge to allege any prior offense that increased punishment. Courts continued to follow the rule throughout the nineteenth century, except for a handful of states that opted to permit prior convictions to be alleged after conviction of the charged offense if those prior offenses had not been alleged in the initial charging instrument and a defendant's first offender status was debunked in prison. ${ }^{140}$

Eventually, in 1912 in Graham v. West Virginia ${ }^{141}$ the Supreme Court addressed this alternative procedure. After Graham had pleaded guilty to larceny and was sentenced to five years in prison, he was charged, in a separate information, of having been convicted twice before. A jury found that allegation proven beyond a reasonable doubt, and he was resentenced to life in prison. The Court reasoned that this process was a rational approach for the state to adopt in order to deal with those recognized as former offenders only after they were admitted to prison ${ }^{142}$ and concluded that omitting the prior offense allegation from the initial indictment was not a federal constitutional problem, reiterating that states need not use indictments at all. ${ }^{143}$ After Graham, more states adopted this approach, some of them placing no time limit on the delay in bringing the new allegation and lengthening an offender's incarceration. ${ }^{144}$ But this departure from the common law rule affected

140. The states departing from the common law rule prior to the Court's decision in Graham v. West Virginia, 224 U.S. 616 (1912), were Massachusetts in 1817, see supra notes 26-29 and accompanying text; Virginia in 1819; South Carolina in 1832; West Virginia, which adopted the Virginia practice when it became its own state in 1860, see Oyler v. Boles, 368 U.S. 448, 449-50 (1962); and Kansas, which became a state in 1859. Both Louisiana and Maine for a time allowed post-conviction allegations of repeat-offender status, but this position was later repudiated by the courts in each state. For a listing of 19th Century authority in each state, see infra Appendix.

141. 224 U.S. 616 (1912).

142. Id. at 587 .

143. Id. at 627 (noting that states are free to use information rather than indictment to charge offenses and citing Hurtado v. California, 110 U.S. 516 (1884); Brown v. New Jersey, 175 U.S. 172, 175 (1899); and Maxwell v. Dow, 176 U.S. 581, 584 (1900)).

144. See infra Appendix. 
no more than a handful of states until 1912 and was not followed in the federal courts where the Bill of Rights was fully applicable. ${ }^{145}$ Such a limited development is nothing like the established historical practices that have influenced the Court in its prior Apprendi decisions.

As for the right to have a jury decide prior-offense status, that was the law in virtually every federal and state jurisdiction, from the Founding past World War II. ${ }^{146}$ As late as 1946, only Alabama and Kansas allowed a judge to make this determination instead of a jury. ${ }^{147}$ Whenever a defendant pleaded guilty (and even after conviction by jury trial in the handful of states where repeat status could be charged after conviction), a new jury was empaneled to consider the allegation. Otherwise, when the defendant contested the allegation, it was the same

145. Federal courts, testing the application of the federal repeat-offender statutes passed as part of Prohibition, consistently treated prior convictions as elements of an aggravated offense. See, e.g., Hefferman v. United States, 50 F.2d 554, 555-57 (3d Cir. 1931); Jacobs v. United States, 24 F.2d 890, 891 (D.C. Cir. 1928) ("In a case where a party is proceeded against for a second or third offense under the statute, and the sentence prescribed is different from the first by reason of its being a second or third offense, the fact thus relied on must be averred in the indictment."); Klein v. United States, 14 F.2d 35, 36-37 (1st Cir. 1926); McCarren v. United States, 8 F.2d 113, 114 (7th Cir. 1925) (stating that a prosecutor is required to allege in the indictment or information that defendant has previously been convicted of a violation of the National Prohibition Act); Massey v. United States, 281 F. 293, 298 (8th Cir. 1922) ("The accused is entitled to have the exact charge against him stated in the indictment or information, and to have the verdict of the jury upon the fact of a prior conviction for the same offense, and of his identity with the person so convicted, and it is the duty of the government which prosecutes to allege and prove the existence of the prior conviction of the accused as a fact that may cause a severer penalty to be imposed."); Singer v. United States, 278 F. 415, 419-20 (3d Cir. 1922) (stating that inclusion in the charge was required even if Congress did not so intend); United States v. Noel, 51 F.2d 139, 141 (S.D. Ala. 1931) (holding that a district attorney is required to allege a previous conviction); United States ex rel. Manchbach v. Moore, 2 F.2d 988, 989 (E.D. N.Y. 1924). Congress had passed one other statute boosting penalties for prior offenders before the National Prohibition Act, a 1919 statute punishing second offense mail theft, see supra note 59, but no cases could be located discussing that particular provision.

146. As the Court observed in Spencer v. Texas, 385 U.S. 554, 556 (1967), as of 1967, "The common-law procedure for applying recidivist statutes, ... which requires allegations and proof of past convictions in the current trial, is, of course, the simplest and best known procedure." See generally Annotation, Constitutionality and Construction of Statute Enhancing Penalty for Second or Subsequent Offense, 58 A.L.R. 20 (1929); Brown, supra note 52; Harold Dubroff, Note, Recidivist Procedures, 40 N.Y.U. L. REV. 332 (1965); David S. Sidikman, Note, The Pleading and Proof of Prior Convictions in Habitual Criminal Prosecutions, 33 N.Y.U. L. REV. 210 (1958).

147. See Note, Court Treatment of General Recidivist Statutes, 48 COLUM. L. REV. 238, 241 (1948) (citing KAN. STAT. ANN. \$21-107(a) (1945)) (stating all but one made it a jury question and only Kansas allowed trial to the court); see also infra Alabama and Kansas authority listed in Appendix. By 1968, five additional states had authorized judicial findings. See Dubroff, supra note 146, at $347 \mathrm{n} .89$ (listing statutes from Louisiana, Minnesota, Missouri, Nebraska, and Oregon). 
jury that decided the other elements of the offense. ${ }^{148}$ And there is evidence that juries sometimes chose to nullify these harsh laws, rather than apply them. Observers reported more than one case in which the jury, despite fingerprints and other "unmistakable evidence" that a defendant was indeed a multiple offender, "decided upon its oath that the prisoner was a first offender., ${ }^{, 199}$

Finally, whenever a prior conviction would increase the sentence beyond that available for a first offender, the jury was instructed that it had to find that the government established beyond a reasonable doubt that the offender was the same person who had been convicted earlier. ${ }^{150}$ Justice Cardozo, writing in a 1932 case in which the jury's consideration of the defendant's prior convictions took place after the filing of a supplemental information, explained why:

The answer made to the "accusation" by the verdict of the jury may mean that the defendant will be a free man after a brief term of confinement, or may mean, on the other hand, that he will be a prisoner for life. If the previous convictions had been charged in an indictment, there is no doubt that they must have been proved beyond a reasonable doubt, for they would then have been elements affecting the grade of the offense. We find no token of a purpose to abate the measure of the proof upon an inquiry as to the same elements after guilt has been adjudged. The genius of our criminal law is violated when punishment is enhanced in the face of a reasonable doubt as to the facts leading to enhancement. If that genius is to be expelled, there should be

148. Almendarez-Torres v. United States, 523 U.S. 224, 268 (1998) (Scalia, J., dissenting) ("[T]he Court's hostility to jury determination of prior convictions is quite simply at odds with the manner in which recidivism laws have historically been treated in this country."). Thus, even if the very limited variation in the nineteenth century regarding charging would justify some flexibility for prior conviction allegations under the Sixth Amendment's notice requirement, it would not justify similar flexibility for the jury requirement.

149. The BaUmes LAw 142-43, 164 (Julia E. Johnson ed., 1929). Consider also Swann v. State, 1 A. 872, 872-73 (Md. 1885) (holding, in a case where proof of second offense was clear, that it was error for judge to have responded to jury's question of whether it could find a verdict for a first offense by instructing the jury that it either must acquit or find second offense, but harmless).

150. See Dubroff, supra note 146 , at $341-42$ ("Where ... the defendant denies that he was the person previously convicted, it is the usual rule that the state must prove identity just as it must prove guilt for an ordinary crime. There is likewise little conflict among the states as to the burden of proof the prosecution must sustain, most jurisdictions requiring the criminal standard of proof beyond a reasonable doubt...." (footnote omitted)); see also Spencer, 385 U.S. at 574; M. C. Dransfield, Annotation, Evidence of Identity for Purposes of Statute as to Enhanced Punishment in Case of Prior Conviction, 11 A.L.R.2d 870 (1950) (collecting cases from federal courts and twenty-five states). 
a clear announcement of the purpose to drive it forth from the dwelling it has inhabited so long. ${ }^{15}$

\section{Precedent: Why Almendarez-Torres and Other Cases Do Not Support the Exception}

So much for history. Precedent should not prop up this exception either. The case of Almendarez-Torres v. United States ${ }^{152}$ is considered the chief authority for the prior-conviction exception, ${ }^{153}$ but its basis is no longer viable. The defendant in that case turned up in a Texas jail after he had been deported following a burglary conviction and was charged with reentering the United States illegally. His indictment did not specify whether he was being charged under subsection (a) of the criminal statute that stated that the maximum sentence was two years or subsection (b) that provided for up to twenty years if reentry occurred after being convicted of an aggravated felony. ${ }^{154}$ The defendant pleaded guilty, admitted his prior burglary conviction, ${ }^{155}$ but then argued at sentencing that because his indictment had not alleged his prior conviction, an element of the greater offense defined in subsection (b), he faced at most two years. ${ }^{156}$ The judge disagreed, sentenced him to seven years, and the Supreme Court in a five-to-four decision upheld that sentence. Congress intended that the prior conviction that triggered the eighteen-year increase would be a sentencing factor that the judge could find after conviction, the Court reasoned, not an element of a greater offense. Two years later, when the Court announced in Apprendi that legislatures cannot bypass the right to a

151. People v. Reese, 179 N.E. 305, 305-06, 308 (N.Y. 1932) (internal citations omitted).

152. 523 U.S. 224 (1998).

153. Indeed, Justice Thomas has written that "the exception to trial by jury for establishing 'the fact of a prior conviction' finds its basis not in the Constitution, but in a precedent of this Court." Rangel-Reyes v. United States, 547 U.S. 1200, 1202 (2006) (Thomas, J., dissenting) (citing Almendarez-Torres, 523 U.S. 224), denying cert. to $168 \mathrm{~F}$. App'x 616 (5th Cir. 2006).

154. 8 U.S.C. $\S 1326(a)(2),(b)(2)$ (2012).

155. Brief for the United States at 5-6, Almendarez-Torres v. United States, 523 U.S. 224 (1998) (No. 96-6839).

156. By the time sentencing rolled around, the government and probation officer had realized the maximum sentence under subsection (b) was twenty years, not ten, and had modified the presentence report to reflect this. But the defendant objected and argued that the maximum he faced was actually two years because he had pleaded guilty to an indictment that had charged the offense defined by subsection (a) and had not alleged his prior felony conviction, an element of the greater offense defined by subsection (b). The district court disagreed and sentenced him to just over seven years in prison and two years supervised release. Id. at 7. 
jury trial by designating a fact that raises the maximum sentence as a "sentencing factor" instead of an element, it expressly exempted the fact of prior conviction, cited its decision in Almendarez-Torres, and the "prior-conviction exception" to the Sixth Amendment rule in Apprendi was born.

The Court was wrong to carve out this prior-conviction exception in Apprendi, and it was wrong in Almendarez-Torres. Justice Stephen Breyer's opinion for the Court in Almendarez-Torres rested on several prior decisions, but they do not support the holding. The Court leaned on Graham from $1912^{157}$ and Oyler v. Boles from $1962,{ }^{158}$ both involving defendants who had been convicted and sentenced under the supplemental information approach used in Virginia and West Virginia. ${ }^{159}$ In both cases, the Court rejected claims that failing to allege a prior conviction in the initial indictment violated the due process protections provided by the Fourteenth Amendment. It concluded that the common law practice of including prior conviction allegations in the charging instrument and proving them to the jury was optional in the states. ${ }^{100}$

Importantly, both cases construed the limitations of the Fourteenth Amendment's Due Process Clause on states, and not the scope of the Indictment Clause in the Fifth Amendment at stake in AlmendarezTorres, which does not apply in state courts. ${ }^{161}$ More importantly, both cases were decided before the Court declared that the Constitution required state courts to provide either reasonable notice of the charge ${ }^{162}$

157. See supra notes $141-43$ and accompanying text discussing Graham v. West Virginia, 224 U.S. 616 (1912).

158. 368 U.S. 448 (1962).

159. In Oyler, the defendant's sentence was boosted from an eighteen-year maximum to life after he was charged with being a recidivist. Unlike Graham, whose sentence was also raised to life only after the prior offense allegations were proven to a jury, Oyler admitted that he was the same person named in the habitual information. Id. at 450.

160. Id. at 454 ("The petitioners' claim that they were deprived of due process because of inadequate opportunity to contest the habitual criminal accusation must be rejected in these cases."); Graham, 224 U.S. at 625 ("It cannot be said that the prisoner was deprived of due process of law.... Provision for a separate, and subsequent, determination of his identity with the former convict has not been regarded as a deprivation of any fundamental right.").

161. Graham, 224 U.S. at 623,627 (relying on Hurtado in rejecting the state prisoner's claim and noting that states are not bound by requirements of the Federal Constitution).

162. The Sixth Amendment right to reasonable notice of the charge was not clearly recognized for state defendants until 1967, five years after the decision in Oyler; although dictum suggesting this appeared in 1948. See LAFAVE ET AL., supra note 137, at \&2.6(a) (noting the Court's reliance in Washington v. Texas, 388 U.S. 14, 20 (1967), on the dictum in In re Oliver, 333 U.S. 257, 273 (1948), that had treated the notice guarantee as equal in standing to those other rights, was viewed as indicating that a person's Sixth Amendment 
or the right to a jury trial for criminal cases. ${ }^{163}$ The majority in Oyler also noted that an alternative basis for its decision was that the defendant failed to raise his objection on time. ${ }^{164}$

Two other cases relied on by the Court in Almendarez-Torres have since been overruled, one just this past summer by Alleyne. ${ }^{165}$ The Court also quoted several other cases stating that a prior conviction allegation "goes as to the punishment only" and is not an element of the offense, but all of those cases involved claims that increasing a sentence for a prior conviction was improper punishment for the prior offense. ${ }^{166}$ In

right "to reasonable notice of the charge against him" also was to be selectively incorporated). The Oyler dissenters also pointed out that Graham was decided before the Court had broadened the scope of habeas review of state decisions. Oyler, 368 U.S. at 463 n.2 (Douglas, J., dissenting).

163. See Duncan v. Louisiana, 391 U.S. 145, 149 (1968) (declaring that the Sixth Amendment right to jury trial is part of the due process guaranteed by the Fourteenth Amendment to every state felony defendant).

164. Oyler, 368 U.S. at 454; see also id. at 458 (Harlan, J., concurring) ("Counsel could have requested a continuance in order to look into the validity of the previous convictions or other possible defenses to the recidivist charges, or, if there was any doubt, to establish the identities of the previous offenders. They chose not to do so, and I think this choice forecloses the petitioners' claims that they were not given adequate notice and opportunity to prepare a defense."); L. L. C., Jr. \& T. G. L., supra note 12, at 618 (stating that Oyler obscured rather than clarified the question of advance notice).

165. Almendarez-Torres v. United States, 523 U.S. 224, 247 (citing Walton v. Arizona, 497 U.S. 639 (1990), overruled in part by Ring v. Arizona, 536 U.S. 584 (2002); McMillan v. Pennsylvania, 477 U.S. 79 (1986), overruled by Alleyne v. United States, 133 S. Ct. 2151 (2013)).

166. The phrase was first used by the Court in 1895. Moore v. Missouri, 159 U.S. 673, 677 (1895) ("go as to the punishment only" (internal quotation marks omitted)). In Moore and in McDonald v. Massachusetts, 180 U.S. 331 (1901), the Court addressed claims that the defendant had been punished twice for the prior offense, that such double punishment violated his rights under the Fourteenth Amendment, and that by counting prior convictions that preceded the passage of the prior offender law, the state had violated ex post facto principles in the Federal Constitution. In each case, the Court explained that the state had not violated the Fourteenth Amendment, which was no surprise, considering at the time that Amendment was believed to provide essentially no protection for state criminal defendants other than to bar deliberate differential treatment by race. Federal double jeopardy protections, for example, were not applied to the states until 1969. See Benton v. Maryland, 395 U.S. 784, 794 (1969). Indeed, to emphasize that the Fourteenth Amendment's Due Process Clause had no bearing on state criminal justice, the Court in Moore cited its earlier decision upholding a miscegenation conviction under an Alabama statute that also punished second-offense fornication more severely than for the first offense. Moore, 159 U.S. at 678 (citing Pace v. Alabama, 106 U.S. 583 (1882)).

The Court in Almendarez-Torres also relied on Carlesi v. New York, 233 U.S. 51, 55 (1914) and Gryger v. Burke, 334 U.S. 728, 732 (1948). In Carlesi, the Court rejected a defendant's claim that the subsequent pardon of an offense barred its use as a prior conviction boosting a sentence. Carlesi admitted his prior conviction, and the case presented no issue of pleading or proof. Carlesi, 233 U.S. at 56. In Gryger, the defendant also admitted 
each, the Court explained that the heightened punishment was not punishment for the prior conviction but, instead, "a stiffened penalty for the latest crime."167 None of these cases would be affected by abandoning the exception and overruling Almendarez-Torres.

One holding of the Supreme Court that would be doomed should the Court overrule Almendarez-Torres is Monge v. California ${ }^{168}$ Monge was a three-strikes case decided just three months after AlmendarezTorres by the same five to four majority. The Court acknowledged that if Monge's prior strike had been an element, then retrial would have been barred because an appellate court had found the state's evidence of the strike was insufficient. Because of Almendarez-Torres, however, the Court concluded that the prior conviction was not an element and consequently retrial was not barred. ${ }^{169}$ With nothing but AlmendarezTorres to stand on, Monge will and should fall. ${ }^{170}$

\section{Policy: Managing Jury Prejudice}

Nor should policy arguments keep the exception alive. The justices have worried that allowing a prosecutor to prove prior convictions that raise the sentence range in jury trials like other elements would be unfair to defendants. ${ }^{171}$ This could be a serious dilemma for defendants,

his prior conviction but raised ex post facto and double jeopardy challenges to the sentence increase for his prior conviction. Gryger, 334 U.S. at 729-30. The Court rejected Gryger's argument that the state denied him due process when it failed to appoint him counsel for his trial on the prior conviction allegations, explaining that it had just held that states have no federal constitutional obligation to provide counsel to defendants who pled guilty to noncapital offenses. Id. at 731 .

167. Id. at 732 (emphasis added).

168. 524 U.S. 721 (1998).

169. Id. at $729-34$.

170. If the Court is willing to decouple the treatment under the indictment clause and the right to notice from the right to a jury determination beyond a reasonable doubt, then it could abolish the exception from the jury and burden of proof protections and leave Almendarez-Torres's holding on indictments standing. But a majority appears to believe that element status under the Indictment Clause determines element status under the Jury Clause and vice versa. The Alleyne opinion, for example, repeatedly referred to the concept of notice and to elements that must be included in the indictment. See Alleyne, $133 \mathrm{~S}$. Ct. at 2159-60; see also id. at 2164 (Sotomayor, J., concurring) (noting "prosecutors are perfectly able to "charge facts upon which a mandatory minimum sentence is based in the indictment and prove them to a jury.' Indeed, even with Harris in place, prosecutors already sometimes charge such facts and seek to prove them to a jury" (internal citation omitted) (quoting Harris v. United States, 536 U.S. 545, 581 (2002) (Thomas, J., dissenting))). There is considerable disagreement in the states regarding the notice required for facts that fall within the Apprendi rule. See supra note 137 (collecting authority).

171. E.g., Almendarez-Torres, 523 U.S. at 234-35 ("[T]he introduction of evidence of a defendant's prior crimes risks significant prejudice. Even if a defendant's stipulation were to 
as research has shown that jurors will "infer guilt directly from the existence of prior convictions." reason for the supplemental information procedure when first adopted in Virginia and Massachusetts, as noted above in Part I, it later became one of its most popular justifications. ${ }^{173}$ But the risk that courts will be unable to manage jury prejudice given the need to prove a prior conviction is not a constitutional problem, depriving a defendant of the right to notice and proof beyond a reasonable doubt of an element clearly is. In the 1967 decision Spencer $v$. Texas, ${ }^{174}$ the defendant, who had received timely notice and a jury trial on the prior conviction allegations, argued that due process required states to abandon onestage habitual offender trials and use bifurcated proceedings. The Court disagreed, observing that " $\mathrm{t}] \mathrm{h}$ common-law procedure for applying recidivist statutes... which requires allegations and proof of past convictions in the current trial, is, of course, the simplest and best known procedure." change this basic process. Although several justices have expressed the belief that bifurcation is the better approach, ${ }^{176}$ the Court has yet to mandate it as a matter of constitutional law. It has held, however, that in federal criminal trials, "when proof of convict status is at issue" before a jury, and a defendant offers to stipulate to that status, the Federal Rules of Evidence bar admission of additional information about the prior conviction. ${ }^{177}$

keep the name and details of the previous offense from the jury, see Old Chief $v$. United States, 519 U.S. 172, 178-79 (1997), jurors would still learn, from the indictment, the judge, or the prosecutor, that the defendant had committed an aggravated felony.... [W]e do not believe, other things being equal, that Congress would have wanted to create this kind of unfairness in respect to facts that are almost never contested." (internal citation omitted)).

172. See ROBERTS, supra note 1, at 210; see also Nancy J. King, Juries and Prior Convictions: Managing the Demise of the Prior Conviction Exception to Apprendi (draft available from author).

173. See, e.g., Rand v. Commonwealth, 50 Va. ( 9 Gratt.) 738, 752-53 (1852); Tyson v. Hening, 136 S.E.2d 832, 835-37 (Va. 1964) (citing McCallister v. Commonwealth, 161 S.E. 67 (Va. 1931)); State ex rel. Edelstein v. Huneke, 249 P. 784, 786 (Wash. 1926).

174. 385 U.S. 554 (1967).

175. Id. at 563,566 .

176. See Marshall v. Lonberger, 459 U.S. 422, 438-39 n.6 (1983); D. Michael Risinger, John Henry Wigmore, Johnny Lynn Old Chief, and "Legitimate Moral Force"-Keeping the Courtroom Safe for Heartstrings and Gore, 49 HASTINGS L.J. 403, 425 (1998) (noting that in Spencer "the entire Supreme Court-majority, concurrence, and dissent alike-asserted that, were the decision up to them on a legislative basis, they would adopt a two-stage procedure").

177. Old Chief v. United States, 519 U.S. 172, 190-91 (1997) (interpreting FRE 403 in a 922(g) trial: "The most the jury needs to know is that the conviction admitted by the defendant falls within the class of crimes that Congress thought should bar a convict from 
Moreover, it is not true that treating a penalty-raising prior conviction as an element will irreparably impair the fairness of a jury trial and increase even further the pressure to admit guilt. Courts and legislatures have already developed and applied effective methods of handling these issues. In many states prior convictions are jury questions-in felony firearm cases, ${ }^{178}$ habitual offender cases, ${ }^{179}$ and cases in which a prior conviction elevates a misdemeanor to a felony ${ }^{180}$ or a lesser offense to a greater one. ${ }^{181}$ Courts have managed the risk of prejudice using bifurcation, ${ }^{182}$ requiring courts to accept stipulations to limit what the jury hears about the prior conviction, ${ }^{183}$ allowing the defendant to waive the jury for the prior-conviction element alone, ${ }^{184}$ and barring any mention of a prior conviction if admitted by the defendant, something like a partial plea of guilty. ${ }^{185}$ And they have been doing this for nearly 200 years. ${ }^{186}$

possessing a gun, and this point may be made readily in a defendant's admission and underscored in the court's jury instructions.").

178. E.g., United States v. Wilson, 2013 WL 5716805 (10th Cir. Oct. 22, 2013); State v. Summers, 846 P.2d 490 (Wash. 1993).

179. King, supra note 172.

180. E.g., State v. Oster, 52 P.3d 26, 28-29 (Wash. 2002); State v. Benitez, 302 P.3d 877, 881 (Wash. Ct. App. 2013); State v. Cochrane, 253 P.3d 95, 97 (Wash. Ct. App. 2011).

181. King, supra note 172.

182. Id. Bifurcation is already used to establish other facts deemed elements under Apprendi. See MODEl PENAL CODE: SENTENCING \$ 7.07B reporter's note c at 314-15 (Tentative Draft No. 1, 2007) (listing authority for bifurcated proceedings, including KAN. STAT. ANN. § 21-4718(b)(2), (4) (2006); MINN. STAT. § 244.10, subd. 5(b) (2006); N.C. GEN. STAT. § 15A-1340.16(a)(1) (2006); ORE. REV. STAT. ch. 463, § 3(1), (4) (2006); and WASH. REV. CODE § 9.94A.537(3), (4) (2006)).

183. Old Chief v. United States, 519 U.S. 172, 191-92; King, supra note 172.

184. California, Arizona, and Colorado retained the common law approach early on, requiring the prior conviction be pleaded in the indictment, but permitting the defendant the option of admitting the prior convictions and then barring any mention of them to the jury during the trial of the charged offense, except for impeachment. ARIZ. REV. STAT. ANN. $\S 44-1004$ (1939); People v. Wheatley, 26 P. 95, 96 (Cal. 1891) (describing prior law).

185. For a proposal to allow such selective waiver, see MODEL PENAL CODE: SENTENCING $\$ 7.07 B(8)$ at 299 (Tentative Draft No. 1, 2007).

186. State v. Ferrone, 113 A. 452, 456 (Conn. 1921); Kilbourn v. State, 9 Conn. 560, 56263 (1833); L. L. C., Jr. \& T. G. L., supra note 12, at 614-15 (collecting authority); Sidikman, supra note 146, at 215; McWhorter v. State, 44 S.E. 873, 874 (Ga. 1903) (construing a statute providing for an enhanced punishment for subsequent offenses, the court held that, since the allegation and proof of the prior conviction would tend to prejudice the rights of the defendant, such allegation and proof must not be made until after the prisoner has been convicted of the principal offense). Oregon replaced the common law practice with this approach in 1927 for felonies. See Louise Denae Dale, Criminal Law: Procedure: Propriety of Jury Consideration of Prior Offenses, 5 UCLA L. REV. 320, 320-21 (1958). A number of states adopted this approach after World War II. L. L. C., Jr. \& T. G. L., supra note 12, at 615 n.92 (listing authority from Illinois, Maine, Utah, and Washington). 
As for the policy reason that initially led to the alternative charging practice from which the exception grew, that reason has vanished. The departure from the common law that allowed courts to increase sentences based on criminal history alleged only after conviction was built on the realities of a world that no longer exists, when a person's true identity was unknowable, before technology made accessing an individual's image, aliases, prints, and criminal history easy and cheap. Identification today no longer must await commitment to prison. Instead, it occurs in plenty of time for prosecutors to include prior convictions that raise the sentence range in the initial charging instrument. This information is routinely retrieved before or soon after arrest. Law enforcement has been submitting and retrieving fingerprints electronically through the FBI's Integrated Automated Fingerprint Identification System for about fifteen years. ${ }^{187}$ The largest biometric database in the world, it contains fingerprints and criminal histories for more than seventy million people and reportedly matches fingerprints in an average time of thirty minutes. ${ }^{188}$ All fifty states and the District of Columbia have been participating since $1993 .{ }^{189}$ Even though the difficulty of identifying prior offenders may once have provided a reason to allow prosecutors to postpone allegations and proof of criminal history until after conviction, that reason no longer exists. ${ }^{190}$

187. James Jacobs \& Tamara Crepet, The Expanding Scope, Use, and Availability of Criminal Records, 11 N.Y.U. J. LEGIS. \& PUB. POL'Y 177, $210-11$ (2008).

188. Fingerprints \& Other Biometrics, FED. BUREAU OF INVESTIGATION, http://www.fbi.gov/about-us/cjis/fingerprints_biometrics/ngi (last visited Dec. 13, 2013); Integrated Automated Fingerprint Identification System, FED. BUREAU OF INVESTIGATION, http://www.fbi.gov/about-us/cjis/fingerprints_biometrics/iafis/iafis (last visited Dec. 13, 2013).

189. National Criminal History Improvement Program, BUREAU OF JUSTICE STATISTICS, http://www.bjs.gov/index.cfm?ty=tp\&tid=47 (last visited Dec. 13, 2013).

190. There is yet another rationale that has been advanced to justify why prior convictions, unlike other facts that raise sentencing ranges, need not be proven to a jury beyond a reasonable doubt-namely, that the defendant already had those same protections for the prior conviction. E.g., Jones v. United States, 526 U.S. 227, 249 (1999) (explaining that the recidivism exception was permitted because "a prior conviction must itself have been established through procedures satisfying the fair notice, reasonable doubt, and jury trial guarantees"); Descamps v. United States, 133 S. Ct. 2276, 2300 (2013) (Alito, J., dissenting) (rejecting the need to limit proof to prevent violations of the Sixth Amendment jury trial right and arguing that, "When the modified categorical approach is used to decide whether 'a jury was actually required to find all the elements of [a] generic [offense],' the defendant has already enjoyed his Sixth Amendment right to a jury determination of those elements" (quoting Taylor v. United States, 495 U.S. 575, 602 (1990))); Andrew Sokol, Juvenile Adjudications as Elevating Factors in Subsequent Adult Sentencing and the Structural Role of the Jury, 13 U. PA. J. CONST. L. 791, 798-99 (2011) (stating that the exception can be reconciled with the rationale of Apprendi only because the facts necessary to prove the prior conviction in the first instance were presented to a jury that adjudged them true beyond a 


\section{E. Stare Decisis: Eroded Doctrine, Shifting Votes}

If all of the possible justifications for the prior-conviction exception to the Apprendi rule are as weak as suggested here, the Court is unlikely to decide that stare decisis warrants keeping it on life support any longer. Justices Antonin Scalia, Clarence Thomas, and Ruth Bader Ginsburg have already made their opposition to the exception clear, ${ }^{191}$ so its demise would require only two more votes from Justices Stephen Breyer, Sonia Sotomayor, or Elena Kagan. In Alleyne, Justice Breyer agreed to overrule as "anomalous" the Court's decision exempting facts that raise the minimum sentence from the Apprendi rule, a decision that he had authored. The exception for prior convictions is equally, if not more, anomalous, and he may be ready to overrule his prior opinion for the Court in Almendarez-Torres as well. And the justification that Justices Sotomayor and Kagan provided in Alleyne is equally applicable here: When prosecutors are perfectly able to charge and prove these facts to a jury, "stare decisis does not compel adherence to a decision whose 'underpinnings' have been 'eroded' by subsequent developments of constitutional law." presenting the issue squarely, including a case remanded for reconsideration in light of Alleyne. ${ }^{193}$

reasonable doubt). But this "previously enjoyed rights" theory misses two key points. First, a jury found someone guilty beyond a reasonable doubt, but it may not have been this defendant. Second, the theory fails entirely to address the lack of notice that results when a defendant is asked to decide whether to contest an alleged offense before he learns that because of a prior offense, conviction would carry a much longer sentence.

191. See, e.g., Descamps, 133 S. Ct. at 2294-95 (Thomas, J., concurring); Shepard v. United States, 544 U.S. 13, 26-28 (2005) (Thomas, J. concurring); Monge v. California, 524 U.S. 721, 737-39 (1998) (Scalia, J., dissenting); Almendarez-Torres v. United States, 523 U.S. 224, 247-70 (1998) (Scalia, J., dissenting); Rangel-Reyes v. United States, 547 U.S. 1200 (2006) (Thomas, J., dissenting) (citing Almendarez-Torres, 523 U.S. 224), denying cert. to 168 F. App'x 616 (5th Cir. 2006)

192. Alleyne v. United States, 133 S. Ct. 2151, 2164-66 (2013) (Sotomayor, J., concurring). Commentators and lower courts have detailed how the foundation for the rule in Almendarez-Torres has been eroded as well. E.g., United States v. Adame-Orozco, 607 F.3d 647, 651 n.6 (10th Cir. 2010) (questioning the continuing viability of Almendarez-Torres); Nichols v. United States, 563 F.3d 240, 243 n.1 (6th Cir. 2009) (noting a question concerning the status of the Almendarez-Torres decision).

193. See United States v. Abrahamson, 731 F.3d 751, 752 (8th Cir. 2013) ("Because the challenged enhancement of Abrahamson's sentence was based solely on his prior felony drug conviction, it continues to fall under the recidivism exception to the jury presentation requirement that the Court recognized in Almendarez-Torres and left unchanged in Alleyne."). Understandably, courts of appeals are dutifully applying the Court's precedent, but often note its uncertain future. E.g., United States v. Torres-Alvarado, 416 F.3d 808, 810 (8th Cir. 2005) ("While it is unclear whether Almendarez-Torres and its felony exception will remain good law, we are bound by Almendarez-Torres until the Supreme Court explicitly 
Discarding the exception for prior convictions will finally end cases like David Appleby's. ${ }^{194}$ Appleby pleaded guilty to two charges: thirdoffense DUI and third-offense driving on a revoked license. At his plea proceeding, he was informed that his maximum sentence on each charge was three years, for six years total. Not until after his plea and conviction did the prosecuting attorney file a "recidivist information," which alleged that Appleby was "the same person who has been five times previously convicted in the State of West Virginia for crimes punishable by confinement in a penitentiary, [and] should be sentenced to be confined in the state correctional facility for life."195 A jury found Appleby to be the same person who was convicted before, and the judge sentenced him to life in prison. In 2010, a divided panel of the Fourth Circuit, relying on Almendarez-Torres, rejected Appleby's constitutional challenge. But in dissent, Judge Traxler cut to the heart of the problem: "Appleby was sentenced to life on the charges to which he pleaded guilty after being told that he could be sentenced to no more than six years." 196 It is time for the Court to require prosecutors in West Virginia to do what prosecutors elsewhere seem to have no trouble doing: determine whether the defendant is eligible for repeat-offender punishment, decide whether to pursue that punishment, and provide formal notice of that intent before conviction..$^{197}$

The Court cannot have it both ways: If a recidivist premium is not additional punishment for the prior convictions, then it is punishment for the charged offense, and the Constitution requires that the defendant be informed of the actual maximum sentence he faces if convicted of that charged offense, before he decides whether or not to admit it. And whenever a higher sentence range turns on the presence of a prior conviction, that fact must be alleged as part of the charge and proven like any other element.

overrules it." (internal citation omitted)).

194. See Appleby v. Warden, 595 F.3d 532 (4th Cir. 2010).

195. Id. at 534.

196. Id. at 544 (Traxler, J., dissenting) (emphasis altered).

197. Unlike most state courts, see LAFAVE ET AL., supra note $136, \S 21.4$ (d), courts in Washington and West Virginia have held that if application of a habitual criminal statute is not automatic and would require commencement of a separate proceeding, then it is a collateral consequence about which the defendant need not be warned. State v. Ward, 869 P.2d 1062, 1075 (Wash. 1994). Consider also United States v. Rodriquez, 553 U.S. 377, 383-84 (2008) ("If the judge told the defendant that the maximum possible sentence was 10 years and then imposed a sentence of 15 years based on ACCA [a provision authorizing a higher sentence for those with prior convictions], the defendant would have been sorely misled and would have a ground for moving to withdraw the plea."). 


\section{CONCLUSION}

We need not eliminate the use of criminal history in allocating punishment. Compared to alternative reasons for calibrating sentences, criminal history will continue to have the advantage of relative objectivity and widespread public support. ${ }^{198}$ Escalated penalties for prior offenders are here to stay. But the way in which these punishments are applied will and should change.

State courts, legislatures, and sentencing commissions are already revisiting the use of criminal history in sentencing to respond to the Court's expansion of the Apprendi rule, to incorporate risk assessment tools, and to trim corrections costs. ${ }^{199}$ Whenever these provisions are considered, lawmakers should take the opportunity not only to bring these rules into compliance with the Constitution, but also to revise them in light of new information about their effects. ${ }^{200}$ For example, if a criminal history aggravator is supposed to isolate the most violent offenders for incapacitation, then the prior convictions that trigger lengthier sentences should be narrowed to those that predict that type of behavior, and parole or similar release provisions should be made available for those who by anyone's measure do not pose that risk, such as the elderly and the very ill. $^{201}$ If the goal of a provision is incarcerating those most likely to reoffend, then it should not increase sentences based on features of criminal history that have little predictive

198. Hannah-Moffat, supra note 90 , at 290 (noting that the use of an objective measure like criminal history is attractive for the same reason numerical guidelines and risk scores are: they "standardize decision-making criteria, enhance the defensibility of decisions, and insure that all the players in the system are working with the 'same information," allowing judges and prosecutors to defend their decisions to the electorate); see also Frase, supra note 134, at 119 ("[A]ccurate prior conviction information is more readily available than most other evidence supporting the underlying rationales, and lends itself to simpler decision rules.").

199. Such as in California, last year adopting Proposition 36 to narrow the scope of eligible offenses and thereby reduce the number of nonviolent offenders sentenced to life under these provisions. See CAL. PENAL CODE $§ 1210$ (a) (West Supp. 2004); see also MODEL PENAL Code: Sentencing $\$ 6 \mathrm{~A} .07 \mathrm{cmt}$. b at 135 (Tentative Draft No. 1,2007 ) ("II]ncremental adjustments in variables such as criminal-history scoring may have substantial aggregate effects.").

200. See also Hannah-Moffat, supra note 90, at 291 (urging legislators and courts to "pay [more] attention to how, why, and based on what 'evidence' [they] can justify [deprivations] of liberty based on risk scores" and past convictions); Petersilia \& Turner, supra note 102, at 175 (calling for "researchers and policymakers in each state [to] discuss openly the objectives of their guidelines and establish the correlation of commonly used factors with both recidivism and race for their criminal populations...to address the equity issue in an informed light").

201. See generally Model Penal Code: Sentencing $\S 305.1$ at 65 (Tentative Draft No. 2, 2011). 
power. ${ }^{202}$ Changes like these may seem small, but the potential impact can be significant, not only for those branded as convicted criminals (although not literally any longer), but for everyone who bears the costs of the use of incarceration to control criminal conduct.

202. See U.S. SENTENCING COMM'N, ANNUAL REPORT 8 (2010) (concluding that additional criminal history points when offense occurred within two years of prior conviction should be eliminated); U.S. SENTENCING COMM'N, COMPUTATION OF "RECENCY" CRIMINAL HISTORY POINTS UNDER USSG 22 (2010) (finding that eliminating "recency points" would have decreased predictive power only slightly but would have reduced the average sentence of affected offenders by $16.3 \%$ ). 


\section{APPENDIX: LAW ON CHARgING PRIOR CONVICTIONS, BY STATE (YEAR STATEHOOD)}

Alabama (1819) appeared to follow the common law rule on charging prior convictions until 1944 even though, from 1909 on, it was one of the very few states that permitted the judge (as opposed to the jury) to determine whether the defendant had been convicted before. See Johnson v. State, 130 So. 777, 778 (Ala. 1930) (citing Carson v. State, 19 So. 32 (Ala. 1896)) (noting that in order for a mandatory minimum hard-labor sentence for second offenders to apply, the "indictment or complaint in the case must aver a violation of the preceding section, making the former conviction a material issue on the trial of the case"); Lyles v. State, 88 So. 375, 376 (Ala. Ct. App. 1921) (noting Act of Jan. 25, 1919, no. 7, § 20, 1919 Ala. Acts 6, 17; Act of June 30, 1915, no. 1, $\S \S 3,14,1915$ Ala. Acts 1, 2, 6; and Act of Aug. 9, 1909, no. 7, § 3, 1909 Ala. Acts 8, 9-10); Rosenberg v. State, 59 So. 366, 368 (Ala. Ct. App. 1912). In 1944, the state's high court held that more severe second and third offender penalties could be imposed without an allegation of the prior offense in the indictment upon a finding of the prior offense by a judge at a "hearing, full and open, in which the defendant should be present and represented by counsel, if he desires, and it should be tried and reported as any other feature of the trial." Yates v. State, 17 So. $2 \mathrm{~d}$ 777, 779-80 (Ala. 1944) (internal citations omitted).

Arkansas (1836) followed the common law rule on charging prior convictions as late as 1951 , although cases since then allow the state to amend the charge to add prior conviction allegations after trial begins. See Finch v. State, 556 S.W.2d 434, 436 (Ark. 1977) (permitting amendment during trial); Robbins v. State, 242 S.W.2d 640, 643 (Ark. 1951) (collecting authority requiring allegation of prior offenses); Hettle v. State, 222 S.W. 1066, 1067 (Ark. 1920) (reversing conviction where indictment did not charge a second offense, noting that "the offense of illegal cohabitation is a graded crime, and the fact of whether it was a first, second, or third offense is an element in the punishment thereof" because "[e]very indictment, for whatever offense, must set out all the facts which in law may influence the punishment for the commission thereof" (quoting Kightlinger v. State, 150 S.W. 690, 690 (Ark. 1912)) (internal quotation marks omitted)); Thomas v. State, 620 S.W.2d 300, 301-02 (Ark. Ct. App. 1981) (permitting the amendment of the information on date of trial to include "habitual offender" charge). 
California (1850) followed the common law rule on charging prior convictions, providing for the portion of the information alleging the prior conviction to be kept from the jury if the defendant admitted or confessed the prior conviction. See State v. O'Neill, 248 P. 215, 217 (Mont. 1926) (discussing California precedent); People v. Meyer, 15 P. 95, 96 (Cal. 1887) (noting that it is error to inform the jury of a previous conviction when the defendant had already confessed to it). It continues to do so, although it switched to bifurcated trials in 1981. See People v. Saunders, 853 P.2d 1093, 1096 (Cal. 1993) (noting decision adopting bifurcation in 1981 and subsequent codification of that requirement); People v. Coleman, 79 P. 283 (Cal. 1904) (holding prior offense properly charged and tried with other elements); People v. Stanley, 47 Cal. 113, 115 (1873).

Colorado (1876) continues to follow the common law rule on charging. See COLO. REV. STAT. ANN. § 18-1.3-801 (West 2013) ("Such former conviction or convictions and judgment or judgments shall be set forth in apt words in the indictment or information."); Lakomy v. People, 178 P. 571, 572 (Colo. 1919) (finding the information properly charged the former conviction, which was an issue before the jury). A 1929 statute authorized the supplemental charging process, but, reasoning that "[i]f the former conviction be not charged, but may be established by evidence, [the] defendant would plead at his peril and might be confronted with a penalty undreamed of," the state's high court held that "[i]f, before trial, the district attorney knows of such, and has any discretion in the matter, he must charge or waive." Smalley v. People, 43 P.2d 385, 385-86 (Colo. 1935); see also People v. Rieger, 128 P.3d 295, 296 (Colo. App. 2005) ("[T]he trial court misinterpreted the plain language of $\$ 18-1.3-803(6)$ when it allowed the prosecutor to file two habitual criminal counts against Rieger after he had pled guilty, despite the prosecutor's prior knowledge of the convictions. Contrary to the trial court's ruling, the statute does not allow a prosecutor, for good cause or otherwise, to add known habitual criminal counts after a guilty plea has been accepted.").

Connecticut (1788) followed the common law rule on charging and still does. State v. Bjorklund, 830 A.2d 1141, 1159 (Conn. App. Ct. 2003); State v. Riley, 110 A. 550, 552-53 (Conn. 1920) (collecting authority) ("[I]f the state intends to make any claim to raise the penalty by reason of such prior conviction, the defendant should in the information be apprised of this additional element upon which such claim of the state is 
to be based. It is accordingly a uniform rule that such additional allegations relating to the penalty alone should be incorporated in the information.... [W]e cannot see why the allegations necessary to invoke the severer penalty provided by the statute in case of two prior convictions are not properly and correctly stated in the information before us."); State v. Ryan, 37 A. 377, 378 (Conn. 1897) ("[T]he existence of a first offense is, of course, one of the essential elements of the charge and must be alleged in some way, or the charge will be fatally defective....").

Delaware (1787) A second offense liquor law was enacted in 1915, and it appears that the prior offense was part of the indictment then. See State v. Legg, 93 A. 556, 557 (Del. 1915). In 1953, a Superior Court decision suggested that the supplemental information was the best approach. State v. Owens, 101 A.2d 319, 320 (Del. Super. Ct. 1953) (stating with regard to the 1953 habitual offender law that "an acceptable procedure ... would consist of something less formal than an indictment but of more dignity than a mere motion. This would be by way of a supplemental information immediately following the fourth conviction for felony. Upon such an information, defendant could be arraigned and plead guilty or not guilty. In the rare case where a not guilty plea is entered, the only normal issue of fact for determination would be whether or not defendant had been convicted four times for felony" (internal citations omitted)); see also Gibbs v. State, 208 A.2d 306, 308 (Del. 1965) ("The origination and evolution of the procedure, used to implement our Habitual Criminal Act, appear in State v. Owens, [101 A.2d 319] and in 11 Del.C. $\S 3912$ [providing for a separate information to be filed anytime before conviction or sentence]. It appears that $\S 3912$ was enacted as the result of the Owens case in which the court noted the lack of a procedure for implementing the Act. The court there prescribed the proceeding by information as a means of utilizing the Act with due regard for the demands of due process of law."). The defendant retained the option of seeking a determination of habitual offender status beyond a reasonable doubt by a jury. See Gibbs, 208 A.2d at 307 n.1 (citing DEL. CODE ANN. tit. 11, § 3912(b)). The statute provided that prior convictions aggravating the punishment for an offense other than those under the habitual offender statute were proven to the judge at sentencing. Gibbs, 208 A.2d at 307 n.1 (citing § 3912(a)); Mergenthaler v. State, 239 A.2d 635, 638-39 (Del. 1968). Today, proof of prior convictions is made at sentencing before a judge, and notice need not be given before conviction, see Roten v. State, No. 
$108,2010,2010 \mathrm{WL} 3860663$, at $* 2$ (Del. Oct. 4, 2010), but the fact of prior conviction must be established beyond a reasonable doubt, see Morales v. State, 696 A.2d 390, 395 (Del. 1997).

Florida (1845) followed the common law rule on charging prior convictions until the passage of a statute in 1927. See Sparkman v. State Prison Custodian, 18 So. 2d 772, 774 (Fla. 1944) ("[I]t is generally necessary to allege in an indictment the fact of a prior conviction, and during the trial support said allegation by admitting into evidence a certified copy of the record or by other competent evidence, in order to subject an accused to the enhanced punishment ...."); Cross v. State, 119 So. 380, 385-87 (Fla. 1928) (upholding second proceeding under second information filed pursuant to 1927 statute, against ex post facto, double jeopardy, right to jury trial, equal protection, and due process challenges, relying upon Graham v. West Virginia, 224 U.S. 616 (1912)); Benson v. State, 101 So. 231, 231 (Fla. 1924) (the jury must expressly determine separately the question of the historical fact of the defendant's former conviction as alleged); State ex rel. Lockmiller v. Mayo, 101 So. 228, 229 (Fla. 1924) (noting a "prior conviction was a necessary element in the so-called felony" when second offense was a felony and first offense a misdemeanor); Smith v. State, 78 So. 530,532 (Fla. 1918) ("The defendant must be charged with having been before convicted of a like offense if it is intended to charge him with the felony of selling liquors as a second offense."); see also Reynolds v. Cochran, 365 U.S. 525, 529 n.6 (1961) (quoting 1957 Florida statute authorizing proceeding at any time after conviction). For prior convictions boosting penalties under other statutes other than its repeat offender provision, Florida courts continued to follow the common law rule. Johnson $v$. State, 229 So. 2d 13, 14 (Fla. Dist. Ct. App. 1969) ("The question that is before us here is whether in those cases where the statute provides increased punishment for the commission of successive related offenses, one may be sentenced as a second or third or subsequent offender without having been so charged and the allegations proved in an adversary proceeding conducted with all due process safeguards. This must be answered in the negative.").

Georgia (1788) followed the common law rule on charging until a 1974 statute permitted prior convictions the state "made known" to the defendant before trial to be found by a judge at a hearing after conviction. See Act of Mar. 20, 1974, no. 854, § 7, 1974 Ga. Laws 352, 357 (codified as amended at GA. CODE ANN. § 27-2503) (providing 
"only such evidence in aggravation as the state has made known to the defendant prior to his trial shall be admissible"); State v. Hendrixson, 310 S.E.2d 526, 528 (Ga. 1984) (relying on $\$ 27-2503$ and upholding life sentence based on prior offenses when those prior offenses were not set out in the indictment); see also Elrod v. Caldwell, 209 S.E.2d 207, 208 (Ga. 1974) ("[T] he appellant was not charged as a recidivist and could not have been sentenced as a second offender by the trial court."); Riggins v. Stynchcombe, 203 S.E.2d 208, 212 (Ga. 1974) (applying a 1969 statute that required a two-stage trial, but holding that "[f]or one to receive recidivist punishment he must have been indicted under a recidivist statute, his prior convictions having been considered by the Grand Jury and having been included in the indictment. In short, one cannot be indicted by a Grand Jury for only one offense carrying a maximum punishment, and then have that maximum punishment increased at the election of the state's prosecuting officers" (emphasis added)); Studdard v. State, 169 S.E.2d 327, 328 (Ga. 1969) ("It would be a travesty of justice to permit an accusation... to charge a felony punishable by imprisonment for one period of time and then to permit evidence to be introduced which would authorize imprisonment for a longer period of time."); Tribble v. State, 148 S.E. 593, 595 (Ga. 1929) ("The fact of a former conviction and sentence must be charged in the indictment, where a second conviction would affect the grade of the offense or require the imposition of a different punishment."); McWhorter v. State, 44 S.E. 873, 874 (Ga. 1903) ("Where the second conviction changes the grade of the offense, or authorizes a higher penalty than could otherwise have been imposed, the former conviction enters as an element into the new offense, and must be alleged as a necessary part of the description and character of the crime intended to be punished."); Hines v. State, 26 Ga. 614, 616 (Ga. 1859) ("The allegation is certainly one of the first importance to the accused, for if it is true, he becomes subject to a greatly increased punishment."); Peavy v. State, 283 S.E.2d 346, 350-51 (Ga. Ct. App. 1981) (holding a separate allegation and jury determination were not required since the 1974 law required "the judge in non-death penalty cases where a guilty verdict is returned to dismiss the jury and conduct a presentence hearing wherein 'the judge shall hear additional evidence in ... aggravation of punishment, including the record of any criminal convictions and pleas of guilty"' (alteration in original) (quoting $§ 27-2503$ )).

Idaho (1890), like California, followed the common law rule on charging and still does, but adopted a bifurcated trial procedure. State v. Roy, 
899 P.2d 441, 443 (Idaho 1995) ("In State v. Johnson, this Court announced a procedure to be followed where a criminal defendant is charged under the persistent violator statute (I.C. § 19-2514). In such a case the information must be prepared in two parts, the first setting forth the substantive offense charged, and the second alleging prior convictions. The trial must also be bifurcated. During the first phase, the jury should be read only the first part of the information. The trial should then proceed as if there were no allegations of prior convictions. Only if the jury returns a guilty verdict on the substantive charge should the second part of the information be read and the jury allowed to consider the recidivist charge." (internal citation omitted) (citing State v. Johnson, 383 P.2d 326, 331-32 (Idaho 1963), wherein the court adopted a bifurcated trial but still required the reading of allegations included in the initial charge, with one part of the information read to the jury and the other read only upon conviction of the first part)); State v. Lovejoy, 95 P.2d 132, 134 (Idaho 1939) ("[F]ormer convictions relied on must be alleged in the indictment or information and proved at the trial[,] and the identity of the defendant as the person formerly convicted must be established beyond a reasonable doubt."); State v. Scheminisky, 174 P. 611, 611-12 (Idaho 1918) (holding when an accused is charged with being a persistent violator of the law, "the former conviction[s] must be alleged in the indictment or information and proved at the trial").

Illinois (1818) followed the common law rule on charging when it adopted its repeat larceny statute in 1867 and its habitual offender statute in 1883. See Act of June 28, 1867, § 1, 1867 Ill. Laws 37, 37-38; Act of June $23,1883, \S 1,1883$ Ill. Laws 76,76 . It continued to follow that rule in repeat-offender cases until the habitual offender statute was amended in the late 1950s. See ILL. REV. STAT. ch. 38, § 603.3(a) (1959) (described in People v. Williams, 599 N.E.2d 913, 918 (Ill. 1992), as including a revision that provided in part that "[a] former conviction of a felony shall not be alleged in the indictment, and no evidence or other disclosure of such conviction shall be presented to the court or the jury during the trial of the principal offense"); People v. Robinson, 656 N.E.2d 1090, 1099 (Ill. 1995) (explaining that, prior to the 1978 amendment, the Habitual Criminal Act involved alleging a defendant's qualifying convictions in the indictment and proving them at trial, but the amendment changed the Habitual Criminal Act to a sentencing provision); People v. Hayes, 429 N.E.2d 490, 491 (Ill. 1981) (refusing to hold that "because the prior conviction elevates the degree of the 
offense from a misdemeanor to a felony it should be necessary, at the risk of prejudice to the accused, that it be alleged in the information and proved"); People v. Long, 123 N.E.2d 718, 721 (Ill. 1955) ("Unless controlled by statute, it is generally held that in order to subject an accused to the enhanced punishment for a second or subsequent offense, or as an habitual criminal, it is necessary to allege in the indictment the fact of the prior conviction."); Featherstone v. People, 62 N.E. 684, 685-87 (Ill. 1901) (requiring the former conviction or convictions to be "set forth in apt words in the indictment" (citing $\S 1$, 1867 Ill. Laws at 37-38; $§ 1,1883$ Ill. Laws at 76); People v. Ramey, 317 N.E.2d 143, 148 (Ill. App. Ct. 1974) (holding "it is necessary to allege the previous conviction in the indictment in order to assess the enhanced penalty").

Indiana (1816) codified the common law rule on charging and proof before a jury in a 1907 statute, see Act of Feb. 28, 1907, ch. 82, § 1, 1907 Ind. Acts 109, 109, reenacted in 1926 and thereafter, see Smith v. State, 87 N.E.2d 881, 883 (Ind. 1949); Kelley v. State, 185 N.E. 453, 455 (Ind. 1933). Bifurcation was not required, see Sammons v. State, 199 N.E. 555, 558 (Ind. 1936); Barr v. State, 187 N.E. 259, 261 (Ind. 1933), until 1972 when the state's high court adopted the Connecticut bifurcated process, see Shelton v. State, 602 N.E.2d 1017, 1019 (Ind. 1992) ("The habitual offender statute was therefore amended to reflect this bifurcation requirement. Under the statute, a jury is not presented with an habitual offender charge until after it has determined the defendant's guilt or innocence on the underlying felony charge. If the jury finds the defendant guilty, 'the jury ... reconvene[s] for the sentencing hearing' on the habitual offender count." (alteration in original) (internal citation omitted) (quoting IND. CODE ANN. § 35-50-2-8(c) (West Supp. 1992))); Lawrence v. State, 286 N.E.2d 830, 835 (Ind. 1972) ("If they return a verdict of guilty, the second part of the information, in which former convictions are alleged, should be read to them without reswearing them, and they should be charged to inquire on that issue. Of course, the accused may plead guilty to this part of the information, and then no further proceedings before or by the jury would be necessary. No reason appears why the accused, if he should choose, might not submit this issue to the court without the jury." (quoting State v. Ferrone, 113 A. 452, 457-58 (Conn. 1921)) (internal quotation marks omitted). This bifurcated procedure was thereafter extended to other statutes aggravating the penalty for a crime committed by a prior offender, see, e.g., Minor v. State, 792 N.E.2d 59, 61 (Ind. Ct. App. 2003), but not for 
felon-in-possession cases, see Spearman v. State, 744 N.E.2d 545, 548 (Ind. Ct. App. 2001) (rejecting bifurcation for felon in possession cases because "[i]t is not practical, or even possible, to bifurcate the proceedings in this case"). The statute requiring allegations and proof before the jury is still in effect. IND. CODE ANN. § 35-50-2-8(a) (West 2012). The state courts in 1975 found no constitutional barrier to filing the habitual allegation after conviction, relying on Oyler v. Boyles, 368 U.S. 448 (1962), although the practice appears to be to file these allegations at the same time as the substantive offense. Lewis v. State, 337 N.E.2d 516, 520-21 (Ind. Ct. App. 1975) ("[W]e cannot perceive any substantial prejudice to the defendant's rights by permitting the proceedings to determine the applicability of the sentence for recidivists to be initiated after completion of the trial on the substantive offense."); see also Cheney v. State, 486 N.E.2d 508, 514 (Ind. 1985) ("In the case at bar the amendment was filed on September 13, 1983, and trial commenced on October 31, 1983. We find this time period was sufficient to permit appellant to adequately prepare his defense."); Funk v. State, 427 N.E.2d 1081, 1087-88 (Ind. 1981) (noting that in cases where habitual allegations were added after arraignment but before trial, "The right of the State to amend by adding an habitual offender count has specifically been approved by this Court. An information may be amended at any time before, during, or after trial so long as it does not prejudice the rights of the defendant." (internal citation omitted) (quoting Gilmore v. State, 415 N.E.2d 70, 73 (Ind. 1981)) (internal quotation marks omitted)).

Iowa (1846) followed the common law rule on charging and still does, but bifurcated its jury trials in 1966. See State v. Kukowski, 704 N.W.2d 687, 691 (Iowa 2005) (recounting history of two-stage trial requirement); State v. Robinson, 165 N.W.2d 802, 803-04 (Iowa 1969) (noting history of 1966 statute); State v. Smith, 106 N.W. 187, 189 (Iowa 1906) ("[T]he statute requires that the fact of former convictions shall be set forth in the indictment. And this but conforms to the general rule governing criminal procedure... The plea of not guilty puts in issue, not only all matters of fact essential to the instant crime, but the fact of the alleged former convictions of the defendant. Moreover, as we have seen, the statute requires a special finding at the hands of the jury as to the fact of such former convictions." (citations omitted)). Iowa law presently requires the prior conviction to be charged. IOWA CODE ANN. RULE 2.6(5) (West 2002 \& Supp. 2013) ("If the offense charged is one for which the defendant, if convicted, will be subject by reason of the Code 
to an increased penalty because of prior convictions, the allegation of such convictions, if any, shall be contained in the indictment. A supplemental indictment shall be prepared for the purpose of trial of the facts of the current offense only, and shall satisfy all pertinent requirements of the Code, except that it shall make no mention, directly or indirectly, of the allegation of the prior convictions, and shall be the only indictment read or otherwise presented to the jury prior to conviction of the current offense. The effect of this subrule shall be to alter the procedure for trying, in one criminal proceeding, the offenses appropriate to its provisions, and not to alter in any manner the basic elements of an offense as provided by law.").

Kansas (1861) codified a penalty for former offenders before statehood, see State v. Lohrbach, 538 P.2d 678, 681 (Kan. 1975) (citing Act of Feb. 3 , 1859, ch. 28, § 278, 1859 Kan. Sess. Laws 231, 283 (codified at GEN. STAT. KAN. ch. $31, \S 289(1868)$ ), but it did not follow the common law rule. Instead, it permitted notice of the enhanced penalty to be given after conviction. Wasson v. State, 499 P.2d 1128, 1130 (Kan. 1972) ("[T]he seven-day notice given to the appellant, after his entry of a plea of guilty, was sufficient to authorize the state to proceed under the habitual criminal act."); Chance v. State, 408 P.2d 677, 681 (Kan. 1965) ("It has never been the rule in Kansas that a defendant in a criminal action must be apprised by the State prior to conviction that the State intends to invoke the habitual criminal act."). Kansas statutes also allowed the judge to determine the prior conviction that would raise the penalty range. State v. Woodman, 272 P. 132, 134 (Kan. 1928). Interestingly, the state did follow the common law rule for a different repeat-offender statute. A defendant's former conviction was included in the charge and proven to the jury under a persistent violator liquor statute passed in 1911. See State v. King, 141 P. 247, 248 (Kan. 1914) (terming "former conviction of a violation of the prohibitory law" the other element of the charge to be included in the information). For the high court's explanation of the different treatment, see Levell $v$. Simpson, 52 P.2d 372, 374 (Kan. 1935) ("The circumspection which our procedure exerts to keep the fact of any former convictions for felonies away from the jury is to protect the accused from the possibility that in his pending trial the jury might conceive a prejudice against him as an habitual criminal. But where a second offense is a separate and distinct crime, it must necessarily be so charged in the information, and the proof to support the charge in all its details would have to be submitted to the jury. We have one such crime in this state; the persistent violation 
of the prohibitory law. A first offense against the prohibitory law (with exceptions not here pertinent) is a misdemeanor punishable by a moderate fine and jail sentence. R.S. 21-2101. But a subsequent infraction of the prohibitory law is quite a different and a more serious crime. It is a distinct felony. R.S. 21-2146. In such a case, all the formalities of a felonious charge should be pleaded in the information. Of necessity, too, every material allegation in such an information would have to be proved to the satisfaction of a jury." (internal citations omitted)).

Kentucky (1792) (a jury sentencing state) followed the common law rule on charging when it adopted its habitual offender statute in 1881 and continues to do so today. See Price v. Commonwealth, 666 S.W.2d 749, 750 (Ky. 1984) ("We interpret the PFO[, Persistent Felony Offender,] statute as requiring that if the Commonwealth seeks enhancement by proof of PFO status, the defendant is entitled to notice of this before the trial of the underlying substantive offense. A separate indictment meets this requirement just as does a separate count in the indictment charging the substantive offense to which it refers."); Taylor v. Commonwealth, 3 Ky. L. Rptr. 783 (1882); Carter v. Commonwealth, 11 Ky. Op. 92, 93 (1881) ("A former conviction must be specifically pleaded, whether presented as a defense to an indictment or inserted in that pleading by the prosecutor with a view of increasing the punishment. The fact that the accused had been previously indicted for a felony, describing the nature of the offense, in a court having jurisdiction, that he was assigned and pled to the indictment, and was found guilty and sentenced, etc., are facts necessary to be alleged. The prisoner must know from the statements contained in the indictment the former convictions relied on."); Stewart v. Commonwealth, 11 Ky. Op. 138, 138 (1881); Clark v. Commonwealth, 324 S.W.3d 747, 749-50 (Ky. Ct. App. 2010) (agreeing with a Texas Court rejecting Oyler as constitutional floor, the court found "that basic due process requires that the defendant be informed of the nature of the charges he is accused and the consequences of a conviction before jeopardy attaches so that he is aware of the potential consequences of a conviction and to prepare a possible defense... [I] $] \mathrm{t}$ is contrary to the basic notion of due process to return a PFO indictment during the trial on the underlying offense" (internal citation omitted)).

Louisiana (1812) passed a repeat offender provision in 1870, and in 1880 the Supreme Court appeared to approve of omitting the prior conviction from the charge, State v. Hudson, 32 La. Ann. 1052, 1053 (1880), but this 
approach was overruled in State v. Compagno, 51 So. 681, 682 (La. 1910) (" $\mathrm{T}]$ he first conviction ... is an aggravation which gives rise to an increase of the punishment... [I]t becomes a part of the second offense. It is the basis of the sentence for increasing the punishment."). After Graham, a new statute in 1928 permitting postsentence allegations and proof before a judge was upheld as constitutional (over the dissent of one justice). See State v. Guidry, 124 So. 832, 835 (La. 1929) ("There is no provision in the Constitution that we have been able to find which authorizes or requires questions of fact not pertaining to the guilt or innocence of a defendant to be submitted to a jury. The act itself does not expressly require, nor does the language by fair implication authorize, the submission to a jury of the fact as to whether the defendant was a second offender."). By the 1970s, a state statute permitted prior offender charges to be filed after initial sentencing, while the defendant was incarcerated. State v. Bullock, 329 So. $2 \mathrm{~d} 733$, 736 (La. 1976) (relating history). The courts later clarified that the common law rule on charging and proof for prior convictions was limited to statutes that enhanced a penalty for a specific type of crime. See State v. Skipper, 906 So. 2d 399, 416-17 (La. 2005) (holding that "La. R.S. 40:982 should be treated as a sentencing enhancement provision after conviction, like La. R.S. 15:529.1, and not as a substantive element of the presently-charged offense"). Under the Louisiana statute providing that the judge may sentence any person convicted for a second or subsequent offense to a double or triple penalty, or to perpetual imprisonment for the fourth offense, it is held that the proof of the former convictions must be heard and passed on by the jury, since "the jury alone has authority to subject an accused party to the double or greater penalty... for the subsequent conviction." State v. Bailey, 115 So. 613, 616 (La. 1927).

Maine (1820), in enforcing its habitual offender law, first departed from the common law rule during the period from 1824 to 1897, see Jenness $v$. State, 64 A.2d 184, 185 (Me. 1949) (noting that section 18 of chapter 282 of the Public Laws of Maine (1824) "provided that the habitual offender when 'convicted' of a felony might be sentenced for a limited term or for life" and that section 19, repealed in 1897, had provided that, "if the prior sentence was not known at the time of indictment and conviction, the warden and prison inspectors had authority to obtain legal process to have the convict tried on the fact of prior conviction"); followed it from 1897 through 1961, see State v. McClay, 78 A.2d 347, 352-54 (Me. 1951) (finding charge was required by the state constitution); again 
permitted prior offense charges to be filed after conviction but before sentencing from 1961 to 1999 , mandating that they be included in an "ancillary" indictment and proven in a separate jury phase after the jury convicted of the underlying offense until 1989, see State v. Heald, 382 A.2d 290, 298 (Me. 1978) (discussing dual indictment process); State v. Melvin, 341 A.2d 376, 380 (Me. 1975) ("[T]he Legislature provided [in 1961] that when the existence of a prior conviction enhances the penalty which may be imposed on a current offense, allegation of the prior offense must be separate from, and its determination must be subsequent to, that of the current offense." (citation omitted)); then made this later pleading optional from 1989 to 1999, see State v. Brooks, 656 A.2d 1205, 1207 (Me. 1995) ("Failure to allege the previous conviction precludes the court from imposing the mandatory minimum penalty...."); Landry v. State, 575 A.2d 315, 316-17 (Me. 1990) (quoting statute as amended in 1989); and finally returned to requiring such allegations up front, continuing to follow the common law rule today, ME. REV. STAT. tit. 17-A, § 9-A (West 2006) ("[A] prior conviction must be specially alleged if the sentencing provision of a crime requires that a present sentence be enhanced because the person has been previously convicted of a specified crime."); ME. R. CRIM. P. 7 ("If a prior conviction must be specially alleged pursuant to 17-A M.R.S.A. § 9-A(1) it may not be alleged in an ancillary indictment, information or separate count thereof but instead must be part of the allegations constituting the principal crime.... Unless the statutory class for the principal crime would be elevated thereby, amendment of an indictment or information for purposes of 17-A M.R.S.A. § 9-A(1) may be made as of right by the attorney for the state at any time prior to the imposition of sentence on the principal crime and sentencing shall be continued until the attorney for the state has been afforded the opportunity to obtain an amended indictment if the allegation must be made by the grand jury.").

When enforcing other repeat offender provisions, Maine has followed the common law rule since at least 1855 . State v. Regan, 63 Me. 127, 128 (1873) (stating in liquor law case that "[f]ormer convictions are alleged, with a view, undoubtedly, to increased punishment"); State v. Robinson, 39 Me. 150, 155 (1855) (discussing the "common thief" statute); see also State v. McClay, 78 A.2d 347, 352 (Me. 1951) ("This section, R.S. 1944, Chap. 57, Sec. 72, and its predecessors are not the source of the rule of criminal pleading which requires that prior convictions be alleged in order that enhanced penalties may or must be imposed upon second or subsequent offenders under statutes providing 
therefor. That rule has its source in the common law. It is preserved by Art. I, Sec. 6 of our Constitution, supra, as a sacred right of, and a protection to, those accused of crime."). Bifurcated trials have been permitted in Maine for more than fifty years. State v. Mottram, 184 A.2d 225, 226 (Me. 1962) ("At his request he was given a separate jury trial on each count. The jury hearing the larceny count was not informed of the 'habitual offender' or second count."); see also State v. Sapiel, 432 A.2d 1262, 1271 (Me. 1981) ("Although 15 M.R.S.A. § 757 requires separate trials for the principal offense and the ancillary proceeding, we conclude that the use of the same jury for both trials did not deprive the Defendant of his right to a fair trial.").

Maryland (1788) followed the common law rule on charging until 1962. See Swann v. State, 1 A. 872, 872 (Md. 1885); Maguire v. State, 47 Md. 485,496 (1878) (holding in a case of conviction for second offense transactions in liquor on the Sabbath, common law required that "if the party be proceeded against for a second or third offense under the statute, and the sentence prescribed be different from the first, or severer, by reason of its being such second or third offense, the fact thus relied on must be averred in the indictment; for the settled rule is, that the indictment must contain an averment of every fact essential to justify the punishment inflicted"); see also Hall v. State, 89 A. 111, 112 (Md. 1913) (indicating that jury must find specially as to the fact of a prior conviction); Goeller v. State, 85 A. 954, 955 (Md. 1912) (striking down second offense statute that provided aggravated penalty after judge, not jury, found prior conviction and holding that the prior conviction should have been alleged in indictment and proven to jury under state constitution). When it adopted second offense drug laws in 1951 , this practice of pleading and proving prior conviction allegations continued. Beard v. State, 140 A.2d 672, 676, 682 (Md. 1958) (rejecting a constitutional requirement that the jury must pass on the accused's alleged prior convictions at the same time that it passes upon the alleged current offense, the court noted that "in the absence of a binding admission by the accused of one or more prior convictions, they should call for special verdicts or findings as to the historical facts of any prior convictions which may be alleged"); Robertson v. Warden, Md. House of Corr., 129 A.2d 90, 91 (Md. 1957). In 1962, new court Rule 713 barred the inclusion of the prior conviction in the indictment, and instead required the state to attach to the indictment notice of the state's intent to prosecute the defendant as a subsequent offender and notice of the defendant's option to have the fact of his prior conviction tried 
"concurrently with the trial for the current offense or be determined by the court or jury after the verdict on the current offense." MD. R. PROC. 713(b) (1962) (repealed 1977) (emphasis added) (discussed in Sullivan v. State, 349 A.2d 663, 665 (Md. 1976)). In 1977, the state judiciary, noting Oyler and Graham, adopted a new Rule 734 that was modeled on the court rule in place in the District of Columbia. The new rule abandoned the procedure of Rule 713 and required that, prior to a guilty plea or trial, the state's attorney serve a notice on the defendant or his or her counsel that the state will seek increased punishment as well as set forth each prior conviction to be relied upon. In 1984, a failure to provide notice before trial of the specific convictions that would be alleged to aggravate the penalty was held to be harmless error. King v. State, 477 A.2d 768, 776 (Md. 1984); see also Lee v. State, 632 A.2d 1183, 1189-91 (Md. 1993) (holding that notice mailed to the defendant and received a reasonable time prior to sentencing meets notice requirement of Maryland Rule 4-245(b) and satisfies due process). Prior conviction allegations in Maryland must be proven beyond a reasonable doubt but need not be proven to a jury. See Dove v. State, 4 A.3d 976, 987 (Md. 2010) ("[T]he State must prove each element of the enhanced penalty statute beyond a reasonable doubt, including the defendant's identity in the previous qualifying convictions."); Testerman v. State, 907 A.2d 294, 301 (Md. 2006) (finding that there was no need for "a collateral factfinding proceeding" because the "critical facts are not in dispute" (quoting In re Parris W., 770 A.2d 202, 207 (2001)) (internal quotation marks omitted)).

Massachusetts (1788) first created the optional supplemental information process in 1817 , then returned to the common law rule later in the nineteenth century. See supra notes 27-29 and accompanying text; McDonald v. Massachusetts, 180 U.S. 311, 312 (1901) (noting that the prior convictions were charged in the indictment under Massachusetts's habitual offender statute); Commonwealth v. Richardson, 55 N.E. 988, 988 (Mass. 1900) (noting that the previous convictions were alleged in the indictment); Tuttle v. Commonwealth, 68 Mass. (2 Gray) 505, 506 (1854) (holding that a prior conviction increasing maximum sentence must be set forth in indictment); Plumbly v. Commonwealth, 43 Mass. (2 Met.) 413, 413-15 (1841); Commonwealth v. Phillips, 28 Mass. (11 Pick.) 28, 34 (1831) ("This proceeding by information to award additional punishment where sentence has already been pronounced, is founded solely on statute, is not known at the common law, is in a high degree penal, and therefore is 
not to be extended by construction beyond the cases clearly contemplated by the statute."); In re Ross, 19 Mass. (2 Pick.) 165, 170 (1824). In 1880, the state's high court found that the state's liquor law, which made it unnecessary to allege previous convictions in the complaint, was contrary to the state's constitution. Commonwealth v. Harrington, 130 Mass. 35, 36 (1880) (citing the state constitution and stating that " $[\mathrm{i}] \mathrm{t}$ follows that the offence which is punishable with the higher penalty is not fully and substantially described to the defendant, if the complaint fails to set forth the former convictions which are essential features of it"); see also Commonwealth v. Briggs, 24 Mass. (7 Pick.) 177, 179-80 (1828) (setting aside defendant's verdict when prosecution failed to provide "proof of identity" of the defendant's prior conviction); Rand v. Commonwealth, 50 Va. (9 Gratt.) 738, 754 (1852) (relying on Briggs and finding failure to allege barred later penalty). Today, "prior convictions are no longer treated as elements," but that "is irrelevant to the requirement under art. 12" of the state constitution. Commonwealth v. Pagan, 834 N.E.2d 240, 247 (Mass. 2005) ("If a defendant is made susceptible to a prescribed statutorily enhanced penalty because of a former conviction, the predicate offense must be alleged in the complaint or indictment."). The state constitution requires that "prior convictions must be alleged in the complaint or indictment and proved" to a jury beyond a reasonable doubt. Id. at 247, 251; see also MASS. GEN. LAWS ANN. ch. 279, § 25 (West 1998 \& Supp. 2013) (habitual offender law).

Michigan (1837) followed the common law rule through the 1920s. People v. McDonald, 206 N.W. 516, 517 (Mich. 1925); People v. Roth, 200 N.W. 136, 136-37 (Mich. 1924); People v. Campbell, 139 N.W. 24, 25-26 (Mich. 1912); People v. Butler, 80 N.W. 883, 883-84 (Mich. 1899); People v. Buck, 67 N.W. 982, 982 (Mich. 1896); People v. Ellsworth, 36 N.W. 236, 238-39 (Mich. 1888). In 1929, the legislature authorized postconviction supplemental informations to be filed. See People v. Eason, 458 N.W.2d 17, 25-26 (Mich. 1990) (relating history); People v. Cairns, 145 N.W.2d 345, 349 (Mich. 1966) (authorizing prosecutor to file supplemental information accusing defendant of prior convictions if "at any time after conviction and either before or after sentence it shall appear that a person convicted of a felony has previously been convicted" (quoting $3 \mathrm{MICH}$. CoMP. LAWs § 17341 (1929)) (internal quotation marks omitted)). For part of this period, this supplemental information could not be filed after conviction if the prosecutor knew about the prior conviction before then. The state legislature amended 
the habitual offender statutes in 1994, making the issue of defendant's status as prior offender no longer a jury question and allowing notice (not an information) to be filed within twenty-one days of arraignment with no exceptions for late discovered priors after conviction. See People v. Morales, 618 N.W.2d 10, 16 (Mich. Ct. App. 2000) (tracing history); People v. Weatherholt, 543 N.W.2d 34, 35 (Mich. Ct. App. 1995); see also MICH. COMP. LAWS ANN. § 769.13 (West Supp. 2013) ("In a criminal action, the prosecuting attorney may seek to enhance the sentence of the defendant as provided under section 10,11, or 12 of this chapter, by filing a written notice of his or her intent to do so within 21 days after the defendant's arraignment on the information charging the underlying offense or, if arraignment is waived, within 21 days after the filing of the information charging the underlying offense." (footnote omitted) (citing $\$ \$ 769.10-769.12)$ ); MICH. R. CRIM. P. 6.112 (F).

Minnesota (1858) followed the common law rule on charging for its repeat offender provision, which passed in 1905 . MINN. STAT. \$ 4772 (1905); see also State ex rel. Carmody v. Reed, 156 N.W. 127, 127 (Minn. 1916) ("It is settled in this state in accordance with the great weight of authority that in order to warrant the imposition of the increased punishment upon second offenders the prior conviction must be charged in the indictment and also established on the trial, if there be a trial, and a verdict of the jury rendered thereon."); State v. Findling, 144 N.W. 142, 143-44 (Minn. 1913) ("We follow and apply the general rule, though it may be remarked, in passing, that entire fairness in prosecutions of this character would suggest some statutory change in the law, dispensing with the necessity of pleading the fact of prior conviction, and providing for the determination thereof by the court after conviction of the charge on trial."). Newer statutes authorizing enhanced penalties for prior conviction without pleading and proof before a jury have been upheld. See, e.g., State v. Ronquist, 600 N.W.2d 444, 450 (Minn. 1999) (noting that "provisions of section 609.346, subd. $2 \mathrm{a}(\mathrm{a})(2)(\mathrm{iii})$ (1996), fall into the category of sentencing considerations and do not constitute elements of the crime to be proven at trial"). Following Blakely v. Washington, 542 U.S. 296 (2004), state law provided for jury findings of facts that triggered aggravated sentences, but state courts have maintained that allegations of such facts in the indictment is not required. E.g., State v. Rodriguez, No. KX-04-319, 2006 WL 6343278, at *A-3 (Minn. Dist. Ct. Aug. 21, 2008) (noting that although not required by the Minnesota Constitution, "the prosecution did set forth the aggravating departure factors that it intended to rely 
upon in the amended complaint in this case prior to the time the defendant entered his guilty pleas. Accordingly, the defendant had constitutionally adequate notice of the aggravating factors that the prosecution intended to rely upon in this case before he entered his guilty pleas").

Mississippi (1817) followed the common law rule on charging until the 1990s. See, e.g., Hentz v. State, 542 So. 2d 914, 918 (Miss. 1989) ("The indictment against an habitual offender must include a charge of habitual offender status sufficient to satisfy notice/due process requirements ...."); Burnett v. State, 285 So. 2d 783, 785 (Miss. 1973); Ainsworth v. State, 40 So. 2d 298, 301 (Miss. 1949); Millwood v. State, 1 So. 2d 582, 583 (Miss. 1941); Brewsaw v. State, 151 So. 475, 476 (Miss. 1933); Hoggett v. State, 57 So. 812, 813 (Miss. 1912) ("Where a greater punishment may be inflicted for a second or subsequent violation of a penal law than for the first, the fact that the offense is a second or subsequent violation must be directly averred in the information or indictment, to justify the increased punishment; else it will not be considered as an offense for which the increased punishment can be inflicted, but will be deemed to be the first offense." (quoting 10 THE ENCYClop/edia of Pleading AND PRACTICE 489 (William $M$. McKinnery ed., 1898)) (internal quotation marks omitted)); Norton $\mathrm{v}$. State, 3 So. 665, 666 (Miss. 1888) ("The judgment of the court below was also erroneous for the reason that it imposed upon appellant the penalty prescribed for the second offense under the local option act, when there was no allegation in the indictment as to its being such offense."). A 1995 ruling upheld an amendment to add a habitual offender notice on the eve of trial on the basis that it concerned only sentencing. Burrell v. State, 727 So. 2d 761, 766 (Miss. Ct. App. 1998).

Missouri (1821) has followed the common law rule on charging prior convictions under its repeat offender law since it was first enacted in 1835. See Moore v. Missouri, 159 U.S. 673, 676-77 (1895) (discussing Missouri case law upholding its habitual offender provision); State v. Nolan, 316 S.W.2d 630, 633-34 (Mo. 1958) (discussing the constitutionality of the Habitual Criminal Act); State v. Krebs, 80 S.W.2d 196, 198 (Mo. 1935) (discussing history); State v. Moore, 26 S.W. 345, 346-47 (Mo. 1894) ("[S]everal previous convictions may be lawfully set out in the indictment when the object in setting them out is only to justify a severer punishment."); State v. Austin, 21 S.W. 31, 32 (1893) ("[I]t needs no citations or argument to prove that the indictment under 
it must allege all the material facts which constitute the offense, so as to bring the defendant within the provisions of the statute... [I]t is a material and essential averment that the felony charged was committed after a former conviction for an offense punishable by imprisonment in the penitentiary.... There is no hardship in requiring the state to inform a man of the nature and cause of the accusation against him before requiring him to defend his life or liberty."); State v. Lehr, 16 Mo. App. 491, 491 (1885). Present law requires prior offenses to be included in the "indictment or information, original or amended, or in the information in lieu of indictment," State v. Johnson, 150 S.W.3d 132, 136 (Mo. Ct. App. 2004), but since 1959, the statute has authorized a judge, not the jury, to determine whether the government has proven those prior convictions, see State v. Morton, 338 S.W.2d 858, 861 (Mo. 1960); see also Mo. ANN. STAT. §558.016 (West 2012); State v. Taborn, 412 S.W.3d 466, 474 (Mo. Ct. App. 2013) (striking down sentence when state failed to plead and prove defendant to be a persistent offender).

Montana (1889) followed the common law rule until 1967, when a statute required "notice" of the prior conviction allegation to be provided to the accused before plea or trial and that the prior conviction allegation be tried to the court, not the jury, after conviction. See State v. Cooper, 489 P.2d 99, 101-02 (Mont. 1971) (discussing Act of Feb. 28, 1967, ch. 196, § 1, 1967 Mont. Laws 353, 400 (codified as amended at Rev. Code. MonT. § 95-1506); Mont. CODE ANN. § 46-13-108 (West 2013) (same process today). Compare State v. Nelson, 304 P.2d 1110, 1113-15 (Mont. 1956), with State v. O'Neill, 248 P. 215, 217 (Mont. 1926), and State v. Gordon, 90 P. 173, 177 (Mont. 1907), and State v. Howard, 77 P. 50, 51 (Mont. 1904).

Nebraska (1867) followed the common law rule on charging for its repeat offender provision passed in 1929, and it still does. Wiese v. State, 294 N.W. 482, 484 (Neb. 1940); NEB. REV. STAT. § 29-2221 (2008); see also Wozniak v. State, 174 N.W. 298, 299 (Neb. 1919) (same, liquor law passed 1917); Osborne v. State, 211 N.W. 179, 183 (Neb. 1926) (liquor law). In 1947, a state statute continued to require that the prior offenses be included in the indictment or information but shifted determination of that status to the judge. See Haffke v. State, 30 N.W.2d 462, 469 (Neb. 1948) ("[T] he above statute by its terms applies only to the Habitual Criminal Act, yet it announces rules of practice and procedure that, as a matter of sound public policy, should apply to any 
statute which imposes the duty upon a court to inflict a greater punishment upon the repetition of an offense.").

Nevada (1864) followed the common law rule on charging requiring inclusion in the indictment, but a 1929 Act authorized the judge to determine the allegations beyond a reasonable doubt. See Howard v. State, 422 P.2d 548, 549 (Nev. 1967) (noting that a 1967 statute required inclusion in the charge but barred the jury from learning about the allegation during trial of the underlying offense, providing that if contested, the allegation would be determined by a judge beyond a reasonable doubt after conviction of the underlying offense); State v. Bardmess, 7 P.2d 817, 818 (Nev. 1932) ("[I]t is proper that he should be informed of the fact that his former convictions will be invoked that his punishment may be increased ...."). For some time habitual charges could be brought after conviction, but a 2013 statute now requires them, absent a showing of good cause, to be filed before trial. See Act of June 1, 2013, ch. 292, § 1, 2013 Nev. Stat. 1373, 1373 (to be codified at NEV. REV. STAT. ANN. $\$ 207.016(2)$ ) ("Procedure; trial of primary offense; prior convictions"); see also NEV. REV. STAT. ANN. $\$ 200.485(4)$ (LexisNexis 2012) (providing, for third offense (felony) domestic violence: "The facts concerning a prior offense must be alleged in the complaint, indictment or information, must not be read to the jury or proved at trial but must be proved at the time of sentencing and, if the principal offense is alleged to be a felony, must also be shown at the preliminary examination or presented to the grand jury" (emphasis added)); NEV. REV. STAT. ANN. § 484C.400(2) (LexisNexis 2010) (same for third offense (felony) driving under the influence).

New Hampshire (1788) followed the common law rule on charging prior convictions until a 2002 case, citing Almendarez-Torres $v$. United States, 523 U.S. 224 (1998), overruled prior precedent. See State v. LeBaron, 808 A.2d 541, 543-45 (N.H. 2002), overruling State v. Lantaigne, 371 A.2d 1170, 1171 (N.H. 1977) (prior conviction must be alleged in charge); Cedergren v. Clarke, 112 A.2d 882, 883 (N.H. 1955); State v. Adams, 13 A. 785, 785 (N.H. 1888) ("It is true, the heavier sentence for a subsequent offense cannot be imposed in the absence of an allegation and proof of a prior conviction."); see also State v. Stickney, 808 A.2d 546, 548 (N.H. 2002) (relying on LeBaron to find jury need not determine prior offense status); State v. McLellan, 767 A.2d 953, 957-58 (N.H. 2001) ("[A] prior conviction need not be alleged in the indictment,... [but] the Due Process Clause of the New Hampshire 
Constitution requires proof beyond a reasonable doubt of prior convictions used to enhance a defendant's sentence to life without parole under the provisions of RSA 632-A:10-a, III."); State v. Small, 14 A. 727, 727 (N.H. 1888) (finding indictment deficient for second offense).

New Jersey (1787) followed the common law rule on charging initially. See Weeks v. State, 127 A. 345, 345 (N.J. Sup. Ct. 1925) ("Where there is a different and greater punishment for a second offense, the settled law seems to be that an offense is considered a first offense, unless a former offense of the same kind is alleged in the indictment and proved on the trial."). In 1931, a statute authorized dispensing with the prior offense allegation in specific cases and was soon upheld by the state courts as constitutional. See State v. Burns, 57 A.2d 1, 2 (N.J. 1948); State v. Mowel, 184 A. 620, 620-21 (N.J. 1936); State v. Myers, 55 A.2d 661, 663 (N.J. Sup. Ct. 1947); State v. Rowe, 181 A. 706, 709-10 (N.J. Sup. Ct. 1935) (citing Graham v. West Virginia, 224 U.S. 616 (1912)). A supplemental accusation or information alleging the prior conviction was required prior to sentencing, however. See State v. Laird, 135 A.2d 859,867 (N.J. 1957) (noting that "N.J.S. 2A:85-13 provides that if 'at anytime, before sentence,' a prior conviction is made to appear, the county prosecutor shall file an accusation charging the previous conviction, and there shall then be a hearing on notice to determine the fact"); State v. Johnson, 262 A.2d 238, 244 (N.J. Super. Ct. App. Div. 1970); State v. Booker, 212 A.2d 849, 852 (N.J. Super. Ct. App. Div. 1965). Although a 1947 case seemed to suggest that statutory delegation of the adjudication of prior conviction allegations to the judge was constitutional, State v. Lutz, 52 A.2d 773, 774 (N.J. Sup. Ct. 1947) ("The usual practice is to allege the prior convictions in the indictment, and to submit the factual issue thereby arising to the jury; and this course is obligatory save where the statute makes other adequate provision for the inquiry, which is not the case here."), by 1950 it was held that proof beyond a reasonable doubt before a jury was required, even if the allegation is filed separately, see State v. Janiec, 74 A.2d 605, 607 (N.J. Super. Ct. App. Div. 1950) ("It is the well settled rule that before the imposition of such a sentence, the defendant must be tried and convicted by a jury under an indictment specifically charging the prior convictions, or that a separate proceeding thereafter be undertaken before a competent court and jury to determine the liability of defendant to punishment as an habitual criminal and that, to meet the issue, the defendant has the same rights to a speedy trial, a time for 
preparation, assistance of counsel, compulsory process for witnesses, to be confronted with the witnesses against him, to require proof beyond a reasonable doubt, and to all other rights enjoyed by a defendant on trial for a criminal offense. To impose a sentence of life imprisonment as an habitual criminal without conforming to the procedure mentioned, would be a clear violation of defendant's guaranties of due process under the Federal and State Constitutions. The refusal of the defendant at the hearing on the Information to either admit or deny his prior convictions was equivalent to a plea of not guilty and clearly imposed upon the State the duty to proceed to have the issue tried and determined before the court and a jury." (internal citations omitted)). In 1953, a statute provided for an independent judicial "hearing on the issue of habitual criminality." See Worbetz v. Goodman, 136 A.2d 1, 9 (N.J. Super. Ct. App. Div. 1957) ("[T]he previous conviction upon which the increased sentence will rest may be alleged in the main indictment and established at trial, and an independent proceeding to adjudicate defendant to be an habitual criminal is unnecessary. A plea of guilty or admission of the prior convictions at trial waives the need for formal proof by the State."). Today, the persistent offender statute requires only proof before a judge with adequate written notice. See N.J. STAT. ANN. \& 2C:43-7.1 (West 2005); State v. Franklin, 871 A.2d 692, 699 (N.J. Super. Ct. App. Div. 2005).

New York (1788) followed the common law rule on charging initially. E.g., People ex rel. Cosgriff v. Craig, 88 N.E. 38, 39 (N.Y. 1909); Johnson v. State, 55 N.Y. 512, 514 (N.Y. 1874) (stating "this has been the uniform practice in this State" regarding second offense grand larceny (emphasis added)); People v. Powers, 6 N.Y. 50, 51 (N.Y. 1851); People v. Youngs, 1 Cai. 37, 39-40 (N.Y. Sup. Ct. 1803). This changed in 1926 when a new statute provided that the district attorney could file an information accusing the prisoner of the previous conviction after conviction or sentence on the underlying offense, and that allegation carried the right to jury trial. Act of Apr. 16, 1926, ch. 457, $\S 3,1926$ N.Y. Laws 805, 805 (codified as amended at N.Y. PENAL LAW § 1943); People v. Gowasky, 155 N.E. 737, 739 (N.Y. 1927); People v. Simmons, 226 N.Y.S. 397, 404 (N.Y. Kings Cnty. Ct. 1927) ("That the adoption of the latter procedure in this state was motivated by the same consideration that caused the enactment of the Massachusetts and West Virginia statutes is shown by the report of the Joint Legislative Committee on the co-ordination of civil and criminal practice acts (Baumes Committee Report) [N. Y. Legis. Doc. 1926, vol. 17, No. 84], page 22) ...." (alteration in original)); 
see also People v. Reese, 179 N.E. 305, 306 (N.Y. 1932); Howard McLellan, The Baumes Laws, in 6 THE REFERENCE SHELF, THE BAUMES LAW 48, 52-54 (Julia E. Johnson ed., 1929) (describing change in the law requiring wardens to "inform courts of newly discovered records of old offenders which may have escaped the other authorities" and life sentences imposed on six prisoners after their arrival at the prison revealed prior convictions). Current law requires written notice of the allegation of prior conviction status before sentencing and an opportunity to insist the prior convictions be proven beyond a reasonable doubt to a judge. See N.Y. PENAL LAW $\S \S 400.15$ (second violent felony offender), 400.16 (persistent violent felony offender), 400.19 (second child sexual assault felony offender), 400.20 (persistent felony offender), 400.21 (second felony offender or second felony drug offender) (Consol. 2012).

North Carolina (1789) followed the common law rule on charging from its beginning through most of the twentieth century, requiring the allegations in the initial indictment and proof to a jury. State v. Miller, 75 S.E.2d 242, 243 (N.C. 1953) ("Where a statute prescribes a higher penalty in case of repeated convictions for similar offenses, an indictment for a subsequent offense must allege facts showing that the offense charged is a second or subsequent crime within the contemplation of the statute in order to subject the accused to the higher penalty."); State v. Fowler, 136 S.E. 709, 710 (N.C. 1927) ("[A]ggravated punishment prescribed for a subsequent conviction cannot be imposed, unless the prior conviction, which is an essential part of the description of the second offense, is charged in the indictment."); State v. Davidson, 32 S.E. 957, 958 (N.C. 1899) ("[N]o previous conviction for larceny being alleged in the bill, it was erroneous to pass sentence of imprisonment for more than one year."); State v. Allen, 10 N.C. (3 Hawks) 614, 616 (N.C. 1825); State v. Daniel, 10 N.C. (3 Hawks) 617, 617 (N.C. 1825); State v. Negro Adam, 10 N.C. (3 Hawks) 188, 190 (N.C. 1824); State v. Woodson, 272 S.E.2d 167, 168 (N.C. Ct. App. 1980) ("[U]pon a proper charge of a second violation of G.S. 20-138, allegation and proof of the first conviction is necessary where, as here, it is not judicially admitted by the defendant."); State v. Williams, 203 S.E.2d 399, 401 (N.C. Ct. App. 1974) ("Neither of the warrants in the case at bar alleged that the offense charged was a fourth or subsequent offense, therefore, the maximum punishment authorized in either of the cases is a fine not exceeding $\$ 50.00$ or imprisonment for not more than 30 days."). A 1967 habitual offender statute permitted jury trial on prior 
conviction allegations be postponed until after guilt on the underlying offense but continued to require that those allegations be filed, in a separate information, before trial or plea. See State v. Allen, 233 S.E.2d 585, 588 (N.C. 1977) ("One basic purpose behind our Habitual Felons Act is to provide notice to defendant that he is being prosecuted for some substantive felony as a recidivist. Failure to provide such notice where the state accepts a guilty plea on the substantive felony charge may well vitiate the plea itself as not being knowingly entered with full understanding of the consequences. Since the statute makes no distinction between guilty pleas and jury verdicts of guilt the same notice requirement prevails in either event." (citations omitted)). This procedure continues to be followed today. State v. Hoskins, 736 S.E.2d 631, 632 (N.C. Ct. App. 2013) ("During the trial on the principal offense, the defendant's potential status as an habitual felon on the basis of prior convictions is not brought to the attention of the jury in considering the principal offense. If the defendant is convicted on the principal offense, then the court begins the 'habitual felon' phase of the trial and the same jury determines whether the defendant has attained the status of an habitual felon." (citation omitted)).

North Dakota (1889) followed the common law rule on charging initially. State v. O'Neal, 124 N.W. 68, 69 (N.D. 1909) (highlighting a state's attorney's failed attempt to prove such former conviction); State v. Markuson, 73 N.W. 82, 86-87 (N.D. 1897) ("[I]t shall be sufficient briefly to allege such conviction." (quoting N.D. REV. CODES $§ 7614$ (1895)) (internal quotation marks omitted)). In 1927, the state legislature adopted the supplemental information procedure, permitting habitual offender allegations to be filed before sentence was fully executed and to be proven before a new jury. Ryan v. Nygaard, 297 N.W. 694, 698, 701-02 (N.D. 1941). In cases in which the prior conviction increased the penalty, other than those under the habitual offender statute, the state courts continued to insist upon inclusion of prior offender allegations in the complaint, information, or indictment, as well as proof beyond a reasonable doubt to the jury. State v. Edinger, 331 N.W.2d 553, 555 (N.D. 1983); State v. Ruble, 40 N.W.2d 794, 803 (N.D. 1950). In 1987, the state's high court held that a written statement of prior convictions would provide sufficient notice under the Sixth Amendment and that specific convictions need not be alleged in the charging instrument. State v. Gahner, 413 N.W.2d 359, 363 (N.D. 1987). Today, several statutes require prior offense allegations to be included in the complaint, information, or indictment, see N.D. CENT. CODE 
ANN. § 19-03.1-23(5) (LexisNexis 2009); N.D. CENT. CODE ANN. § 12.123-11(3) (LexisNexis 2012), or filed prior to plea or trial, see id. §12.132-09(3)). The state bifurcates jury proceedings for dangerous special offender cases, but not habitual offender allegations, which are decided by the judge. Id. $\S 12.1-32-09(4)$. Defendants may stipulate to prior convictions, barring proof before the jury. State v. Tutt, 732 N.W.2d 382,384 (N.D. 2007).

Ohio (1803) followed the common law rule on charging initially with increased penalties for subsequent offenders, see Larney v. City of Cleveland, 34 Ohio St. 599, 600-01(Ohio 1878) ("The rule, and the principle upon which it is founded, are well stated by Mr. Bishop: 'Where the offense is the first, or is prosecuted as such, the indictment need not charge it to be the first, for this is presumed. But if it be the second or third, and the sentence is to be heavier by reason of its being such, the fact thus relied on must be averred in the indictment; because, by the rules of criminal pleading, the indictment must always contain an averment of every fact essential to the punishment to be inflicted.' See 1 Bish. Cr. L., 6th ed., $\$ 961$, and cases there cited. The same rule applies to an information." (quoting JOEL PRENTISS BISHOP, COMMENTARIES ON THE CRIMINAL LAW $\S 961$ (6th ed. 1877)), and in its first habitual offender law in the late 1880s, see In re Kline, 6 Ohio C.C. 215, 216-17 (Cir. Ct. 1892) (noting that the previous felonies were charged in the indictment). It did so until 1987, when it stopped requiring such allegations be pleaded or proved as elements "where the existence of a prior conviction enhances the penalty for a subsequent offense, but does not elevate the degree thereof." See State v. Allen, 506 N.E.2d 199, 201 (Ohio 1987). Pleading and proof before a jury continues to be required when the prior conviction elevates the degree of crime. See State v. Gordon, 276 N.E.2d 243, 245 (Ohio 1971) ("[T]he question of a prior conviction is an essential element of the offense charged, and is an issue of fact to be determined by a jury." (quoting Sparkman v. State Prison Custodian, 18 So. 2d 772, 774 (Fla. 1944)) (internal quotation marks omitted)); State v. Day, 651 N.E.2d 52, 54 (Ohio Ct. App. 1994) ("A prior conviction which raises the degree of a later offense is an element of the subsequent offense."); State v. Miller, No. CA2011-02-13, 2012 WL 764907 (Ohio Ct. App. Mar. 12, 2012) (following Day).

Oregon (1859) followed the common law rule on charging from the outset. State v. Newlin, 182 P. 133, 135 (Or. 1919) (finding "that it was error to adjudge the defendant guilty of a second offense and sentence 
him accordingly, in the absence of an allegation in the indictment charging the prior conviction, and this seems to be the general holding of the courts"); id. at 136 ("[S]uch a sentence was not authorized in the absence of a proper allegation in the indictment."). The rule was codified in 1921 but repealed with the enactment of a new habitual offender law in 1927, adopting the supplemental information procedure permitting allegations of prior convictions to be filed after sentencing, then proved to a new jury. The statute was upheld in 1929. See State v. Smith, 273 P. 323, 325 (Or. 1929) (citing Graham v. West Virginia, 224 U.S. 616 (1912)); see also State v. Waterhouse, 307 P.2d 327, 332 (Or. 1957) (noting that from 1927 through 1957, even as reenacted and amended, "the habitual criminal law has provided a post trial procedure for proving prior offenses"). The state continued to require that prior conviction allegations be included in the initial charge in cases in which the legislature had not provided for an alternative procedure. Id. at 332-33. Reacting to the Waterhouse decision, the state legislature provided in 1961 that all such prior conviction allegations be omitted from the indictment and proven to the court, a provision upheld against constitutional challenge in 1963. State v. Hoffman, 385 P.2d 741, 744 (Or. 1963). Today, these allegations need not be included in the indictment. See State v. Reinke, 309 P.3d 1059, 1060, 1067 (Or. 2013) (" $\mathrm{T}]$ he facts necessary to impose a dangerous offender sentence [must] be found by the grand jury and pleaded in the indictment... [T]he legislature has provided that a prosecutor need not plead sentence enhancement facts in the indictment. Timely written notice will suffice. Defendant's constitutional challenge under Article VII (Amended), section 5, fails." (internal citations omitted) (citing OR. REV. STAT. $\S 136.765(2013)))$.

Pennsylvania (1787) followed the common law rule initially, Rauch $v$. Commonwealth, $78 \mathrm{~Pa}$. 490, 490 (Pa. 1875) ("[T] o subject the defendant to imprisonment it must be charged in the indictment that he had before been convicted of such offence; the rule applies to misdemeanors as well as felonies."); Smith v. Commonwealth, 14 Serg. \& Rawle 69, 70 (Pa. 1826), until 1929, when it gave its prosecutors up to two years after a defendant was sentenced to charge him as a repeat offender and boost his sentence, see Commonwealth ex rel. Foster v. Ashe, 8 A.2d 542 (Pa. 1939) (citing Act of Apr. 29, 1929, no. 854, $\$ 4$ (codified as amended at 19 PA. STAT. \& 924)). Section 9714(d) of title 42 of the Pennsylvania Statutes now vests discretion in the sentencing judge and has been clearly recognized by Pennsylvania's highest state court. 
Commonwealth v. Samuel, 961 A.2d 57, 176-80 (Pa. 1943). For other crimes with higher penalties for subsequent offenses, allegations were to be included in the indictment, but the prior conviction allegations were to be kept from the jury, permitting the defendant to decide if and when convicted, whether to contest them. Commonwealth v. Koczwara, 155 A.2d 825, 831 (Pa. 1959); Commonwealth v. Orwan, 18 Pa. D. \& C.2d 423,428 (Ct. Quar. Sess. 1959) ("We would add thereto that should the jury find defendant guilty of one or more of the offenses set forth in the copy of the original indictments with the averment of prior conviction deleted, the jury should not be discharged until defendant answers the rule to show cause. Should he deny his identity as the person formerly convicted, the question of his identity would then become a jury question."); Commonwealth v. Scott, 54 Pa. D. \& C. 243, 252 (Pa. Ct. Quar. Sess., Dauphin Cnty. 1945). Waivers of the right to notice and proof were also upheld. Commonwealth v. Moses, 271 A.2d 339, 340 (Pa. 1970) ("The lower court lacked the power to impose this enlarged sentence when the indictment did not contain averments of prior convictions."); Commonwealth ex rel. Firmstone v. Burke, 103 A.2d 476, 479 (Pa. Super. Ct. 1954). In 2004, the state's high court held that Apprendi's exception for prior convictions supported the conclusion that failure to plead and prove to a jury a prior conviction that raises the maximum sentence does not violate either the federal or state constitution. Commonwealth v. Aponte, 855 A.2d 800, 811 (Pa. 2004) ("Where...the judicial finding is the fact of a prior conviction, submission to a jury is unnecessary, since the prior conviction is an objective fact that initially was cloaked in all the constitutional safeguards, and is now a matter of public record.").

Rhode Island (1790) followed the common law rule on charging initially. See State v. Flynn, 11 A. 170, 171 (R.I. 1887) (construing a statute punishing "every person who shall have been convicted three times within a period of six months of intoxication, under such circumstances as to amount to a violation of decency, or who shall be proved to have been thus intoxicated three several times within a period of six weeks, shall be deemed a common drunkard" (quoting Act of 1882, ch. 244, $\S 24,1882$ R.I. Pub. Laws 684, 688) (internal quotation marks omitted)). It enacted its first habitual offender provision in 1896. By 1956, the statute permitted the state to bring habitual allegations after sentencing, to be determined by a judge. State v. DeMasi, 420 A.2d 1369, 1370 (R.I. 1980). Since at least 1983 the state courts have rejected any requirement to plead the prior conviction allegations in the indictment. See State v. 
Hall, 940 A.2d 645, 660 (R.I. 2008); State v. Sitko, 457 A.2d 260, 262 (R.I. 1983) (noting recidivism allegation must be made before sentencing). Currently, the statute requires notice be provided "within forty-five (45) days of the arraignment, but in no case later than the date of the pretrial conference." R.I. GEN. LAWS ANN. § 12-19-21 (2002 \& Supp. 2013).

South Carolina (1788) permitted increased penalties for subsequent convictions without allegations in the indictment in 1832. State v. Allen, 42 S.C.L. (8 Rich.) 448,449 (S.C. 1832) ("If, upon a verdict of guilty, the solicitor is able to produce the record of a former conviction of the prisoner for horse stealing, he may move for sentence of death, which the Court would be bound to pass."); State v. Smith, 42 S.C.L. (8 Rich.) 460 (S.C. 1832); see also State v. Parris, 71 S.E. 808, 809 (S.C. 1911) (relying on Smith and Allen and finding that the previous conviction allegation should have been stricken from the indictment). Such information had to be included in the indictment when the information is necessary to establish jurisdiction of the court. Tyler v. State, 145 S.E.2d 434, 435 (S.C. 1965) ("[T] he allegation of the indictment that the crime charged was a second or subsequent offense was necessary to show the jurisdiction of the court."). In 1995, the state's habitual offender statute was amended to require notice at least ten days before trial. Act effective Jan. 1, 1996, 1995 S.C. Acts 568 (discussing amendment); State v. Burdette, 515 S.E.2d 525, 527 (S.C. 1999).

South Dakota (1889) followed the common law rule on charging initially, including allegations of prior convictions that raised the penalty in the indictment. E.g., State v. Kinney, 221 N.W. 250, 250 (S.D. 1928) ("[A] former conviction is an essential element of the second or subsequent offense charged as a felony, and, being an essential element of the crime, must be alleged in the information and proved on the trial."); State v. Schaller, 207 N.W. 161, 161 (S.D. 1926) (stating, in a liquor case, that "[i]t is a well-established rule that, where the statute imposes an additional penalty for subsequent convictions, the information upon the subsequent offense should allege the prior conviction"); State v. Carlisle, 139 N.W. 127, 130 (S.D. 1912) (allegation included in indictment). Under the 1919 habitual offender act, prior convictions were alleged in the indictment. E.g., State ex rel. King v. Jameson, 13 N.W.2d 46, 48 (S.D. 1944); State v. King, 252 N.W. 36, 37 (S.D. 1934). In 1927, the state adopted a version of New York's habitual offender statute, permitting a separate, supplemental information to be 
filed after conviction and a sentence on the underlying offense to be tried to a jury. See State ex rel. Smith v. Jameson, 19 N.W.2d 505, 506 (S.D. 1945); State v. DeMarsche, 1 N.W.2d 67, 68-69 (S.D. 1941) (finding a greater penalty may not be imposed after initial sentencing if judge knew of prior convictions at initial sentencing). Other statutes increasing the degree of offense for defendants with prior convictions also required a separate "Part II" information charging those convictions be filed with the initial charge. Black v. Erickson, 191 N.W.2d 174, 176-77 (S.D. 1971) ("Our procedure requires the allegation of prior convictions to be included in the information charging the principal offense as Part II thereof. SDCL 23-32-9... . [O]ur habitual criminal procedure 'satisfies due process by granting an accused timely and formal notice of the alleged prior convictions before pleading to the primary charge."' (quoting State v. Steffenson, 178 N.W.2d 561 (S.D. 1970))). The two-step charging process is still followed, and from 1959 to 2005 , the statute required "[a]ny allegation that a defendant is an habitual criminal shall be filed as a separate information at the time of, or before, arraignment." S.D. CODIFIED LAwS § 22-7-11 (2006). In 2004 , an amendment allowed a judge to grant permission to file after the arraignment, "but no less than thirty days before the commencement of trial or entry of a plea of guilty or nolo contendere." Id. The defendant has a right to a jury determination of the prior offense allegations. Id. $\$ 22-7-12$ ("The defendant shall also be informed of the right to a trial by jury on the issue of whether the defendant is the same person as alleged in the habitual criminal information.").

Tennessee (1796) followed the common law rule on charging until a 1917 statute provided that the prior conviction required for an increased penalty for second offense liquor violation need not be alleged in the indictment. In a 1930 decision, it was upheld as consistent with Graham. See McCummings v. State, 134 S.W.2d 151, 153 (Tenn. 1939); Tipton v. State, 28 S.W.2d 635, 637 (Tenn. 1930). This scheme, however, was struck down in the federal courts as violating due process by not providing adequate notice. See Edwards v. Rhea, 238 F.2d 850, 851 (6th Cir. 1956), aff' $g 136$ F. Supp. 671, 682-83 (M.D. Tenn. 1955) (finding the statute fails to provide due process and granting writ of habeas corpus). Perhaps anticipating this problem, the state legislature in 1950 amended the statute to require inclusion of prior conviction allegations in the indictment. See State v. Wyrick, 62 S.W.3d 751, 764 (Tenn. Crim. App. 2001). Thereafter, state court decisions followed the common law rule. E.g., Warden v. State, 381 S.W.2d 244, 246 (Tenn. 1964) ("[W]here a 
statute provides for proof of prior convictions and requires increased punishment for second or subsequent offenses, the indictment, in order to charge a second or subsequent offense, must aver not only the convictions of prior offenses, but also such circumstances of time and place as to inform the accused of what proofs of prior offenses may be offered against him and enable him to be prepared to make his defense; and an indictment failing in these requisites is invalid and a conviction based thereon is void."); State v. Sanders, 735 S.W.2d 856, 857-58 (Tenn. Crim. App. 1987) (finding that "[a]n accused, who has been convicted of driving while under the influence, may not be sentenced as a recidivist unless his prior conviction or convictions for driving while under the influences are alleged in the indictment or charging instrument," and that it was error for judge rather than jury to find prior conviction). The state's habitual offender statute was repealed in 1989. Judges now find prior convictions at sentencing for multiple, persistent, and career offenders, and the statute has withstood challenges under Apprendi, e.g., Morris v. Fortner, No. M2008-01022-CCA-R3-HC, 2009 WL 690304, at*3 (Tenn. Crim. App. Feb. 26, 2009), but it continues to require notice of prior convictions that will increase penalty prior to plea or trial, TENN. CODE ANN. \$ 40-35-202 (2010). The common law rule continues to be followed for other repeat offender statutes. See State v. Cross, 362 S.W.3d 512, 517 (Tenn. 2012) (requiring that, for a subsequent driving under the influence offense, prior offenses must be alleged in indictment and a bifurcated jury proceeding used, so that if the jury convicts, it would then be informed of the prior conviction allegations).

Texas (1845) followed the common law rule on charging, see Long $v$. State, 36 Tex. 6, 10 (Tex. 1872) (stating that conviction must be alleged, citing the commentaries of Joel Prentiss Bishop), and until 2006 Texas continued to require notice before trial, although it held grand jury review was not required, Brooks v. State, 957 S.W.2d 30, 34 (Tex. Crim. App. 1997). In 2006, state courts upheld notice provided after trial but before sentencing. See Pelache v. State, 324 S.W.3d 568, 577 (Tex. Crim. App. 2010) ("[F]or purposes of conducting a due-process analysis, the determination of whether proper notice of enhancements was given does not require that notice be given within a particular period of time before trial or before the guilt phase is completed."); Villescas v. State, 189 S.W.3d 290, 294 (Tex. Crim. App. 2006) (noting that "due process does not even require that the notice be given before the guilt phase begins, much less that it be given a number days before trial" (citing 
Oyler v. Boyles, 368 U.S. 448 (1962))). Current law requires "enhancement" allegations to be provided before plea and trial.

Utah (1896) followed the common law rule on charging initially, see State v. Anderson, 286 P. 645, 645 (Utah 1930); State v. Bruno, 256 P. 109,110 (Utah 1927) (noting that the state must allege and prove prior conviction beyond reasonable doubt to convict as persistent violator); State v. Aime, 220 P. 704, 704 (Utah 1923); State v. Hurst, 205 P. 335, 337 (Utah 1922), and continues to do so today for its habitual offender statute, see UTAH CODE ANN. § 76-3-203.5 (LexisNexis Supp. 2013) ("The prosecuting attorney, or grand jury if an indictment is returned, shall provide notice in the information or indictment that the defendant is subject to punishment as a habitual violent offender under this section."). For other repeat offender enhancements, however, state courts have held that although pretrial notice is required, a separate jury finding is not. State v. Angus, 581 P.2d 992, 995 (Utah 1978) (firearm enhancement); State v. Martinez, 896 P.2d 38, 41 (Utah Ct. App. 1995) (regarding the multiple sex offender enhancement: "because the enhancement is a punishment, it is most reasonable to view these requirements as coming into play at the sentencing phase of the prosecution").

Vermont (1791) courts continue to follow the common law rule. See State v. Brillon, 995 A.2d 557, 563 (Vt. 2010); State v. Cameron, 227 A.2d 276, 280 (Vt. 1967). The Supreme Court in Apprendi noted that another opinion, State v. Freeman, 27 Vt. 523 (1855), authorized increased punishment for violation of a liquor law on proof of prior convictions without the necessity of pleading them, observing that "the court did not hold that the prior conviction was not an element; instead, it held that the liquor law created only minor offenses that did not qualify as crimes. Thus, the state constitutional protections that would attach were a 'crime' at issue did not apply." Apprendi v. New Jersey, 530 U.S. 466, 508 (2000) (Thomas, J., concurring) (citing Freeman, 27 Vt. at 527).

Virginia (1788) provided for higher punishment for second offenders in an act of 1796. See Rand v. Commonwealth, 50 Va. (9 Gratt.) 738, 746 (1852) ("If any person convicted of ... a felony ... shall commit any such offence a second time, and shall be thereof legally convicted, he shall be sentenced to undergo an imprisonment in said penitentiaryhouse, at hard labor during life ...." (quoting Act of Dec. 15, 1796, ch. 
$200, \S 24,1803 \mathrm{Va}$. Acts 355,358 ) (internal quotation marks omitted)). The state initially followed the common law rule. Commonwealth v. Welsh, 4 Va. (2 Va. Cas.) 57, 57 (1817) (reversing sentence because "the Information in this Case does not state that it is an Information for a second offense, of retailing spirituous liquors, without license, after having been before convicted of a similar offense"). But in 1819, the legislature authorized, as an alternative to the common law procedure, recidivist status to be alleged and adjudicated after conviction. Rand, 50 Va. (9 Gratt.) at 752-53; Brooks v. Commonwealth, 41 Va. (2 Rob.) 845-46 (1843); Commonwealth v. Bryant, 4 Va. (2 Va. Cas.) 465, 466 (1825); L. L. C., Jr. \& T. G. L., supra note 12 . Prior conviction allegations continued to be included in the indictment in second offense larceny and liquor prosecutions. Toler v. Commonwealth, 51 S.E.2d 210, 214 (Va. 1949); Keeney v. Commonwealth, 137 S.E. 478, 482 (1927); Kelley v. Commonwealth, 125 S.E. 437, 438 (Va. 1924); Staples v. Commonwealth, 125 S.E. 319,320 (Va. 1924); Cooper v. Commonwealth, 113 S.E. 863,863 (Va. 1922); Shiflett v. Commonwealth, 77 S.E. 606, 607 (1913) ("It is well settled that where an offense is punishable with a higher penalty, because it is a second or subsequent offense of the same kind, such severer punishment cannot be inflicted unless the indictment charges that it is a second or subsequent offense, because by the rules of criminal pleading the indictment must always contain an averment of every fact essential to the punishment to be inflicted."); Pryor v. Commonwealth, 26 S.E. 864, 865 (Va. 1897); White v. Commonwealth, 79 Va. 611, 615 (1884); Stroup v. Commonwealth, 40 Va. (1 Rob.) 754, 754 (1842). As additional repeat-offense provisions were added, allegations of prior offenses continued to be required in the indictment. See Triplett v. Commonwealth, 186 S.E.2d 16, 17 (Va. 1972) (repeat offense for driving an automobile while under the influence); Young v. Commonwealth, 156 S.E. 565, 566 (Va. 1931) (same); Sears v. Commonwealth, 510 S.E.2d 274, 276 (Va. Ct. App. 1999) (same); see also Washington v. Commonwealth, 616 S.E.2d 774, 779-83 (Va. Ct. App. 2005) (Humphreys, J., concurring) (collecting multiple statutes that make a prior conviction an element of a greater offense and stating that "this Court and the Virginia Supreme Court have consistently held that, for a defendant to be convicted under a recidivist statute, the prior convictions must be charged in the indictment and proved to the jury"). Nevertheless, Virginia courts consider this rule subject to change by the legislature. For example, in 1993, a state court held that, under the drug statute, prior offenses need not be alleged in the indictment in order to 
impose repeat offender penalties. See Able v. Commonwealth, 431 S.E.2d 337, 341-42 (Va. Ct. App. 1993).

Washington (1889) followed the common law rule for its repeat-liquor violation offense. State v. Dale, 188 P. 473, 476 (Wash. 1920); State v. Dereiko, 182 P. 597, 598 (Wash. 1919). But in 1903, it adopted the supplemental information procedure for its habitual criminal law. See State v. Cotz, 161 P. 1191, 1192 (Wash. 1916); State v. Driscoll, 150 P. 2, 3 (Wash. 1915); State v. Rowan, 146 P. 374, 375 (Wash. 1915); State v. Miller, 138 P. 896, 899 (Wash. 1914); State v. Le Pitre, 103 P. 27, 28 (Wash. 1909). Even after a revised statute omitted express reference to the jury trial, it was held that the defendant has a right to jury trial on the prior conviction allegations. See State v. Furth, 104 P.2d 925, 930 (Wash. 1940); State ex rel. Edelstein v. Huneke, 249 P. 784, 785 (Wash. 1926). The statute was replaced by a three strikes statute in the mid1990s that provided for judicial findings on prior convictions. In upholding that statute, the state's high court in a split decision held that, although state precedent conflicted "regarding whether the habitual criminals act contained 'elements' of a 'charge' or was simply a sentencing enhancement statute," a jury trial, proof beyond a reasonable doubt, and "formal charging" were not "constitutionally mandated" but that "early notice of the potential sentence" was "appropriate." State v. Thorne, 921 P.2d 514, 533-35 (Wash. 1996); see also State v. Smith, 75 P.3d 934, 942 (Wash. 2003). In 1969, it was held that when greater penalties followed proof of a prior conviction in drug offenses, neither allegations in the indictment or proof at trial was required, even though they were for other facts that raised the penalty. State v. Nass, 456 P.2d 347, 349 (Wash. 1969).

West Virginia (1863) took with it Virginia's supplemental charging procedure that departed from the common law rule when West Virginia was organized as a separate state. See Graham v. West Virginia, 224 U.S. 616, 623 (1912) (noting that state provisions "were derived from ... the Code of Virginia of 1860"); State v. Graham, 69 S.E. 1010 (W. Va. 1910). In 1943, an amendment "provided that the statute should be invoked only by information filed after conviction rather than by allegation in the indictment upon which the subject was being prosecuted for a substantive offense." See Oyler v. Boyles, 368 U.S. 448, 451-52 n.5 (1962). A jury decision is still required absent waiver, and, although the supplemental information may be filed after the initial sentence, it must be filed in the same term of court as the original 
conviction. See Holcomb v. Ballard, 752 S.E.2d 284, 287-88 (W. Va. 2013) ("[A] trial court is obligated to arraign a defendant on a recidivist information during the term of court in which the defendant is convicted.").

Wisconsin (1848) followed the common law rule on charging for its repeat-larceny statutes. Ingalls v. State, 4 N.W. 785, 791 (Wis. 1880); Rolke v. State, 12 Wis. 570,570 (1860). It followed the same rule for its repeat-offense liquor statutes as well. See Watson v. State, 208 N.W. 897, 898 (Wis. 1926); Paetz v. State, 107 N.W. 1090, 1091 (Wis. 1906) ("This doctrine appears to be so well established that we deem discussion of it wholly unnecessary. The following are some of the many authorities in support of the doctrine that where the statute provides a heavier penalty for the second offense, the first must be alleged in the indictment and proved upon the trial in order to warrant conviction and punishment for a second offense." (citations omitted)). Courts required the prior conviction be alleged before trial in an information before trial but did not require them to be proven along with other elements at the preliminary examination. Dahlgren v. State, 157 N.W. 531, 532 (Wis. 1916). Its habitual offender statute required that allegations of prior convictions be included in the indictment. See WIS. REV. STAT. ch. 193, $\S \S 4736-4738$ (1878). A defendant had the right to a jury finding of a prior conviction that increased the penalty. See Green Bay Fish Co. v. State, 202 N.W. 667, 670 (Wis. 1925).

Wyoming (1890) followed the common law rule on charging initially and still does. See Schuler v. State, 668 P.2d 1333, 1337-38 (Wyo. 1983) ("Prosecutors seeking enhanced sentences under the habitual-criminal statute must bring allegations of habitual criminality under $\S 6-1-110$, W.S.1977 (see n. 1) in the same information with the underlying felony charge.... [T] he long history of criminal pleading in this state requiring a single information to charge both the underlying felony and the prior felonies upon which the State relies to enhance the punishment ...."); Bandy v. Hehn, 67 P. 979, 980 (Wyo. 1902) ("[A]s the fact of a former conviction enters into the offense to the extent of aggravating it and increasing the punishment, it must be alleged in the information and proved like any other material fact, if it is sought to impose the greater penalty."). 